\title{
PRIMITIVO, NAÏF, INGÊNUO: um estudo da recepção e notas para uma interpretação da pintura de Heitor dos Prazeres
}

Dissertação apresentada ao Programa de PósGraduação em Artes, Área de Concentração Artes Visuais, Linha de Pesquisa História, Crítica e Teoria da Arte, da Escola de Comunicações e Artes da Universidade de São Paulo, como exigência parcial para obtenção do Título de Mestre em Artes Visuais sob a orientação da Prof. Dra. Sônia Salzstein Goldberg

São Paulo

2009 


\title{
PRIMITIVO, NAÏF, INGÊNUO: um estudo da recepção e notas para uma interpretação da pintura de Heitor dos Prazeres
}

\begin{abstract}
Dissertação apresentada ao Programa de PósGraduação em Artes, Área de Concentração Artes Visuais, Linha de Pesquisa História, Crítica e Teoria da Arte, da Escola de Comunicações e Artes da Universidade de São Paulo, como exigência parcial para obtenção do Título de Mestre em Artes Visuais sob a orientação da Prof. Dra. Sônia Salzstein Goldberg
\end{abstract}

BANCA EXAMINADORA

DATA DE APROVAÇÃO: 


\section{Agradecimentos}

Em primeiro lugar, agradeço a quem esteve ao meu lado nessa jornada desde o começo acolhendo a pesquisa. Sônia Salzstein Goldberg, provocando e exigindo, incentivando a buscar os melhores caminhos para o desenvolvimento do trabalho.

A todas as pessoas que me receberam nos museus de São Paulo e Rio de Janeiro, disponibilizando acesso ao material utilizado na pesquisa.

A Heitor dos Prazeres Filho pela entrevista, atenção e carinho e Regina pela conversa gostosa e almoço idem.

Aos meus pais, José Luiz Silveira d'Avila e Docelina T. Miranda d'Avila, que caminharam ao meu lado nesse percurso.

Aos meus meninos José Lucas e Glauber e por todas as horas que não pudemos brincar juntos durante esse tempo, sua compreensão e interesse pelo meu trabalho.

E pelas noites em claro, pelas conversas longas, por estar junto sempre, por ouvir, indicar, ler inúmeras vezes o texto, por conhecer tanto a música do Brasil e ensinar muitas coisas, Leonel Costa. 


\section{Resumo}

A proposta da pesquisa consistiu em analisar quatro assuntos pertinentes à compreensão da pintura de Heitor dos Prazeres. Em primeiro lugar, conhecer historicamente o ambiente no qual as obras foram criadas e a relação do artista com o universo do samba carioca, em segundo, recolher análises críticas que atestassem a recepção dessa produção, em terceiro, analisar resquícios ou elementos que comprovem a proximidade da invenção do artista em questão com referências ao imaginário de herança africana que adquiriu expressão no Brasil, definida usualmente como arte afrobrasileira e finalmente, uma análise crítica de algumas obras relevantes produzidas por Heitor, relacionando-as com a produção de arte brasileira contemporânea à do artista em discussão.

Para alcançarmos nossos objetivos a contento, recorremos aos acervos da Fundação Bienal (Arquivo Wanda Svevo), do MAC-USP, do MAM SP, do Museu Afro-Brasil, de Heitor dos Prazeres Filho (que gentilmente concedeu-nos entrevista), do Museu da Imagem e do Som do Rio de Janeiro, do Museu Nacional de Belas Artes do Rio, do MAM RJ, do site porta-curtas da Petrobras que tem em seu acervo um valioso documentário com depoimento de Prazeres; além de toda a bibliografia a respeito da natureza de nosso estudo. O resultado é uma análise crítica em relação aos estereótipos relacionados à obra de Heitor, recorrente também em outros artistas de origem definida como popular.

Palavras-chave: Heitor dos Prazeres, arte brasileira, arte afro-brasileira, samba, pintura. 


\begin{abstract}
The objective of this research consisted in analysing four issues relevant to the comprehension of the painting of Heitor dos Prazeres.First, to know historically the environment where his works were created and the relation between the artist and the"samba carioca".Second, to collect critical analyses which proved the reception of his works of art.Third, to analyse traces or elements that could support the proximity of the invention of the artist with the imaginary of African heritage, which obtained great expression in Brazil and is usually defined as Afro-Brazilian art. Finally, a critical analysis of some important works produced by Heitor, associating them with the production of the Brazilian Art contemporaneous with the artist.

To achieve our objectives successfully we used the collection of "Fundação Bienal"(File Wanda Svevo), the Contemporary Art Museum-USP(MAC), the Modern Art Museum of Sao Paulo(MAM SP), the Afro-Brazilian Museum, the Image and Sound Museum of Rio de Janeiro, the National Museum of Fine Arts of R. Janeiro, the Museum of Modern Art R. Janeiro, the "site porta-curtas" of Petrobras, which has a valuable documentary with an testimony given by Prazeres, the collection of Heitor dos Prazeres Filho(who kindly gave us an interview) and besides these, all the bibliography related to the nature of our study.

The result is a critical analysis of the stereotypes related to Heitor dos Prazeres works, stereotypes that are also recurrent in the work of other artists whose origin is defined as popular.
\end{abstract}

Key words: Heitor dos Prazeres, Brazilian Art, Afro-Brazilian Art, Samba, Painting. 
Sumário

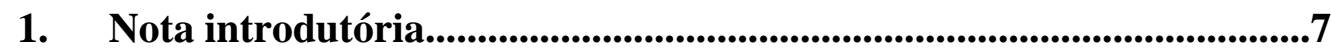

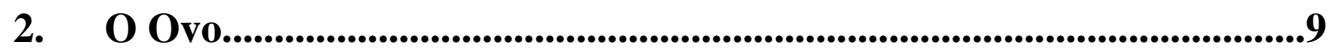

3. A Crítica: Primitivo, Naîf, Ingênuo.........................................................22

3.1 Carlos Cavalcanti.........................................................34

3.2Clarival do Prado Valladares............................................40

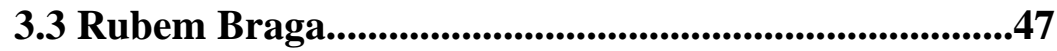

3.4 Carlos Drummond de Andrade........................................50

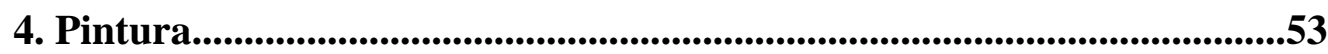

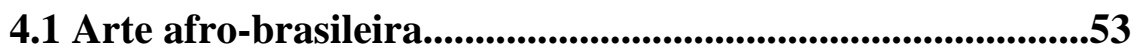

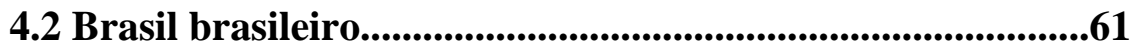

4.3 Pintura de Heitor.....................................................................63

4.4 Moenda e as Bienais......................................................................77

4.5 Estampas para a Rhodia: Brazilian Look...........................85

4.6 Músicos, cotidiano e sapatos.......................................................86

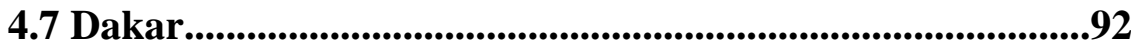

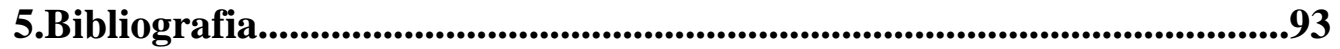

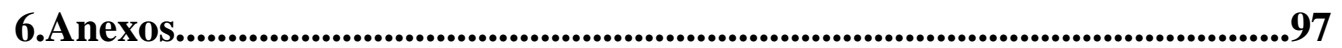




\section{Nota introdutória}

A dissertação presente foi pensada a partir de mais de uma indagação: além da vontade de apresentar a obra de Heitor, tão múltipla, repleta de relações importantes com sua comunidade de origem e formação, inserida num momento fundamental para a discussão a respeito da arte brasileira do século XX, e repensar seu significado (ou significados), tivemos a preocupação de revisar a recepção da obra do artista entre seus contemporâneos, sejam artistas, jornalistas, críticos e público, comprador - ou não - de sua obra.

Decidimos optar pelas análises do jornalista Carlos Cavalcanti, por sua amizade com Heitor e o franco incentivo de Cavalcanti em relação à pintura do sambista tornar-se publicamente conhecida; Clarival do Prado Valladares figura em nossa análise devido à importância de seus estudos em relação à produção afro-brasileira e a proximidade que teve com o artista em questão cuja amizade frutificou em apreciação valiosa a respeito do processo de produção e de aspectos peculiares à obra de Prazeres.

Os escritores Rubem Braga e Carlos Drummond de Andrade representam dois intelectuais respeitáveis na história do Brasil e que foram seduzidos por Heitor tanto por suas qualidades de caráter tanto pela suas artes, arriscando produzir análises para compreender aquela usina criativa que era nosso artista.

Visitar artigos, análises críticas, noções históricas desses autores significa, antes de qualquer coisa, a busca pela construção de conceitos que ao longo do tempo acabaram por consolidar certas noções a respeito da obra de Prazeres.

Outros autores fundamentais como Nina Rodrigues, Arthur Ramos, Gilberto Freyre, são a base do estudo, haja vista que não podemos esquecer a influência desses intelectuais para a noção da formação do Brasil moderno. 
Os termos arte primitiva, naïf e ingênua estão vinculados tão intensamente à leitura da pintura do músico que não pudemos deixar de interpretar essas denominações e o quanto elas estão carregadas de preconceitos ideológicos, de classe, étnicos e racias, reduzindo a amplitude de representação e referências do autor.

Entendemos que a poética de sua arte reside justamente na capacidade do artista em transpor rótulos, o alcance de sua produção era tão amplo cruzando tantas fronteiras, tornando Heitor um interlocutor importante entre a comunidade da Praça Onze, os sambistas descendentes de africanos, entre outras comunidades, a zona Sul do Rio de Janeiro, o governo, intelectuais, artistas de outras origens, colaborando para a divulgação e compreensão de um repertório cultural formador da noção de brasilidade persistente até a atualidade.

Nosso personagem não se esgota tão facilmente, e o desejo de continuar estudando sua obra e sua história transcende esse estudo, apontando mais possibilidades, novos caminhos, que pretendemos seguir e esperamos despertar o interesse em outros que almejam estudar temas como esses, afinal, carecem estudos sobre assuntos semelhantes.

Não seria exagero afirmarmos a dificuldade enfrentada quando nos debruçamos nessa tarefa devido aos poucos, porém importantes estudos sobre a arte e uma reflexão crítica a respeito dos rótulos já citados nessa nota; entretanto, o desafio foi muito mais saboroso e instigante. 


\section{0 ovo}

Não tenho inveja de qualquer atelier em Copacabana, na Tijuca, Ilha do Governador ou outro lugar qualquer grã-fino. A Praça Onze que é o meu negócio. No meu atelier na Praça Onze eu me sinto tão feliz. Me traz recordação da minha infância, me lava a alma aquele apito da Brahma, aquela Brahma que me traz recordação da minha infância, da minha juventude. Me faz lembrar. Me sinto tão feliz como que eu esteja na casa da minha família, a minha família que já não existe mais e outras pessoas mais: tia Ciata e outras pessoas mais.

Eis o motivo de por que me sinto feliz na Praça Onze. Esta Praça Onze que é a Cidade Nova. É o meu bairro, o bairro que eu tenho amizade, vivo em meu coração. O bairro da Praça Onze que é conhecido de Cidade Nova. Cidade Nova, tradicional Cidade Nova, que é a razão que eu me sinto feliz nesse meu atelier. Vendo meus panoramas da favela, da rua General Pedra, lembrando do meu saudoso colégio São Sebastião. É a Praça Onze, é a Cidade Nova. A minha Cidade Nova. Eu pinto a cidade antiga porque está dentro de mim. A cidade antiga é uma coisa que ainda tenho na recordação. Ainda tenho dentro de mim, então tenho aquele espírito de coisas antigas, o qual eu transporto para meus quadros. A minha pintura são coisas que passaram por mim e eu passei por elas, na minha infância, na minha juventude, no arrabalde, aí nesse mundo infinito. ${ }^{1}$

É importante conhecermos a origem do artista Heitor dos Prazeres, seu ambiente e como ele ecoa em sua obra, que abrange não só uma rica produção pictórica, mas também uma produção múltipla em diversas áreas do universo artístico. A Cidade Nova, a Praça Onze, a Penha, o Mangue e os arcos da Lapa são os cenários recorrentes de suas pinturas, de sua música.

Este não é um texto antropológico. Entretanto, ao vasculharmos o lugar que foi a Praça Onze e seu significado na construção de um repertório cultural para a população do Rio de Janeiro, jaz inevitável que discutamos questões relacionadas a estudos da antropologia urbana e do fenômeno deste ambiente para uma nova acepção de elementos predominantemente oriundos de povos africanos. Como outros povos, os africanos aqui expatriados trouxeram seus repertórios originais, e, com o tempo, por

\footnotetext{
${ }^{1}$ Transcrição de documentário de Antonio Carlos da Fontoura, 1965.
} 
meio de contatos e trocas, foram constituindo verdadeiras lutas pela sobrevivência e gerando novos fenômenos artísticos, como o samba carioca.

Personagem indissociável desse cenário, Heitor dos Prazeres demonstra essa vivacidade dinâmica em suas músicas, pinturas, objetos, coreografias e desenhos. Com isso não pretendemos dizer que haja a cultura negra ou a cultura branca. $\mathrm{O}$ artista tem sempre a liberdade de lançar mão de repertórios culturais de quantos grupos quiser; no caso em questão aqui, porém, é inegável a influência de signos, ritmos e cores pertencentes ao grupo que pretendemos analisar e que teve, durante um período histórico, trocas e vivências que marcam a obra do referido artista.

A presença mítica da Praça Onze, citada por muitos sambistas contemporâneos de Heitor, remete-nos à ideia das nações como "comunidades imaginadas", tal como descritas por Stuart Hall (2003): “as nações [...] não são apenas entidades políticas soberanas, mas comunidades imaginadas". No caso de Hall, sua análise está dirigida às comunidades caribenhas, mas é coerente transpor o conceito para a construção da comunidade da Pequena África.

[...] esta questão (como são imaginadas as nações) é central, não apenas para seus povos, mas para as artes e culturas que produzem, onde um certo "sujeito imaginado" está em jogo. [...] Como imaginar sua relação com a terra de origem, a natureza de seu pertencimento? ${ }^{2}$

No nosso caso, a comunidade imaginada seria a Praça Onze, a África em miniatura, a famosa Pequena África, de acordo com a denominação de Mano Lino apelido dado a Heitor pelos bambas das rodas de samba. A Praça é o lugar da troca, da invenção dessa África imaginada e construída por sua comunidade, permanecendo dessa forma para a posteridade.

\footnotetext{
${ }^{2}$ Hall, Stuart. Da diáspora: identidades e mediações culturais. Org. Liv Sovik. Belo Horizonte: UFMG, 2003, p. 26.
} 
A noção de pertencimento a uma determinada África era importante para aquela comunidade, que se afirmava unida e perseverava apesar das dificuldades impostas.

\begin{abstract}
Nenhum pesquisador do início do século percebeu que a comunidade negra, instalada no Centro da cidade do Rio de Janeiro, criava mais que um gênero, uma cultura musical. Essa é uma das razões pelas quais são tão obscuros os dados sobre a origem do samba carioca. Além disso, o preconceito profundamente encravado em nossa sociedade, especialmente nos anos que se seguiram à abolição da escravatura, impedia que as manifestações culturais e religiosas de negros merecessem sequer liberdade de existir, quanto mais de atrair a atenção dos que, porventura, se interessassem pela história do nosso povo. ${ }^{3}$
\end{abstract}

Estamos falando do começo do século XX, período de cerca de vinte anos após a abolição do trabalho escravo no Brasil. Aquela era uma temporada de difícil afirmação e construção de identidades e lugares sociais para a população herdeira dos trabalhadores cativos, que haviam sido expatriados à força de suas terras no grande e diverso continente africano.

O incômodo provocado pelas manifestações de origem africana não era novidade, como descreveu Nina Rodrigues, em 15 de fevereiro de 1901, no Jornal de Notícias baiano, a respeito do batuque na Bahia no começo do século XX:

Começaram infelizmente, desde hontem, a se exibir em algazarra infernal, sem espírito nem gosto, os celebres grupos africanisados de canzás e búzios, que, longe de contribuírem para o brilhantismo das festas carnavalescas, deprimem o nome da Bahia, com esses espetáculos incommodos e semsaborões. Apesar de n'esse sentido, já se haver reclamado da polícia providencias, é bom, ainda uma vez, lembrarmos que não seria má a prohibição d'esses candomblés nas festas carnavalescas. ${ }^{4}$

\footnotetext{
${ }^{3}$ Cabral, Sérgio. As Escolas de Samba do Rio de Janeiro. $2^{a}$ edição. Rio de Janeiro: Lumiar, 1996, p. 27.

${ }^{4}$ Rodrigues, Nina. Os Africanos no Brasil. São Paulo: Cia. Editora Nacional, 1932, p. 237.
} 
No início do século, a proibição avançou aos poucos na Bahia e também no

Rio de Janeiro, fato corroborado pelo medo das insurreições de negros nas principais cidades:

\begin{abstract}
Salvador, antiga capital, é no início do século XIX uma surpreendente cidade do mundo colonial português. Porto exportador reunindo gente de diversos interesses onde renascia uma forte aristocracia local, porto negreiro abastecendo a região das Minas Gerais, Salvador seria a cidade colonial em que o negro tinha maior presença, onde a chegada de iorubas e islâmicos daria novas cores e significados às fortes tradições festeiras dos bantos. Lá se deflagraram as grandes revoltas urbanas, conflitos que legam à sociedade brasileira da Primeira República o temor de levantes negros nas capitais, expresso pelas instituições policiais por uma duradoura vigilância e intolerância. ${ }^{5}$
\end{abstract}

Em meados do século XIX, a vigilância e as determinações oficiais em

Salvador desencadearam uma diáspora de libertos em direção ao Rio de Janeiro:

Francisco Gonçalves Martins, chefe da policia na época da revolta malê, se torna presidente da província da Bahia de 1849-1853 e, com sua obsessão pelo perigo africano, defende limitar o escravo à esfera da agricultura e coagir os libertos a voltar para a África. Durante sua gestão amplia as exclusões dos escravos a ocupações urbanas, proíbe aos negros o aprendizado de determinados ofícios, estabelece impostos aos artífices urbanos, e aumenta a insegurança com ação repressiva da polícia, que enche as prisões com libertos, aumentando as levas de forros que partem alguns para a África, muitos para o Rio de Janeiro. ${ }^{6}$

Em seguida a esse período, pressões internacionais e o excesso de levantes levaram o governo imperial a forçosamente proibir o tráfico com a África, o que elevou consideravelmente o comércio escravagista interno. Após a década de 70, as plantações de café - que, com a decadência do mercado da cana de açúcar em face de concorrência internacional, havia se tornado o meio de produção preponderante - fomentaram a migração forçada de escravos para as plantações do Rio de Janeiro, de Minas Gerais e de São Paulo.

\footnotetext{
${ }^{5}$ Moura, Roberto. Tia Ciata e a Pequena África no Rio de Janeiro. Coleção Biblioteca Carioca, Funarte, Rio de Janeiro, 1983, p. 19.

${ }^{6}$ Ibidem, p. 31.
} 
Os movimentos abolicionistas se espalhavam pelo Brasil, ora acompanhados por uma ideologia republicana, ora acompanhados por uma ideologia monarquista. Fosse por questões de razões humanitárias ou até por medo, já havia entre as elites um grande número de defensores do fim da escravidão, que finalmente se concretizou com a assinatura da Lei Áurea em 1888.

Ao final do século, temos um Rio de Janeiro com uma população que beirava o milhão de habitantes, sendo somados a estes os milhares de negros oriundos da Bahia. Já com suas alforrias, muitos se instalavam na então capital, atuando em afazeres profissionais tipicamente urbanos.

\begin{abstract}
As pequenas profissões não ligadas diretamente à estrutura capitalista moderna que se impunha com suas regras, ainda permitindo a iniciativa pessoal ou de um grupo descapitalizado, valendo-se de sua força de trabalho e do domínio de alguma técnica, e podendo ser realizadas numa parte da própria moradia em pequenas oficinas improvisadas, na cozinha, ou na própria rua paralelamente à venda, seriam muito exploradas pelos negros na cidade, muitos já tendo ganho experiência, como forros ou escravos de ganho, nesses expedientes na cidade de Salvador. [...]

[...] Pedreiros, ferradores, alfaiates, sapateiros, barbeiros, ferreiros, marceneiros, ilustradores, tecelões, pintores de parede ou tabuletas, torneadores, estofadores, serradores (não senadores), tintureiros, costureiras, bordadeiras, lavadeiras, doceiras, arrumadeiras, artesãos, vendedores ambulantes de seu próprio trabalho ou de quinquilharias, de roletes de cana, bilhetes, refrescos, livretos, e de toda a sorte de coisa miúda, o "faz-tudo", crianças com bala, biscoitos, se defendendo e ajudando as pequenas unidades familiares. ${ }^{7}$
\end{abstract}

Tal diáspora favoreceu a organização de uma elite baiana na capital federal de

então. Nessa elite, floresceram novos costumes, que mais tarde contribuiriam para a formação de uma cultura considerada uma das maiores expressões nacionais:

Assim, sob a proteção da bandeira branca de Oxalá, continuam chegando ao Rio de Janeiro, nos porões de navios que faziam escala no porto de Salvador, negros baianos livres, principalmente das nações sudanesas, em busca de uma sociedade mais aberta onde pudessem se afirmar, superando os traumas da escravatura. Os primeiros que conseguem uma situação na capital, um lugar para

\footnotetext{
${ }^{7}$ Ibidem, p. 67-68.
} 
morar e cultuar os orixás e uma forma de trabalho, não hesitam em fornecer comida e moradia aos que vão chegando, o que permitiu um fluxo migratório regular até a passagem do século (XX), garantindo uma forte presença de baianos no Rio de Janeiro.

De fato, os baianos se impõem no mundo carioca em torno de seus líderes de candomblé e dos grupos festeiros, se constituindo num dos únicos grupos populares no Rio de Janeiro, naquele momento, com tradições comuns, coesão, e um sentido familístico que, vindo do religioso, expande o sentimento e o sentido da relação consangüínea, uma diáspora baiana cuja influência se estenderia por toda a comunidade heterogênea que se forma nos bairros em torno do cais do porto e depois na Cidade Nova, povoados pela gente pequena tocada para fora do Centro pelas reformas urbanísticas. [...] Ali, os baianos forros migrados por opção própria constituíram uma elite no meio popular e, generalizando-se as informações dos seus sobreviventes e descendentes, pode-se supor serem predominantemente nagôs (iorubas). ${ }^{8}$

No interior dessa elite, havia muitas Tias baianas - figuras centrais na organização política e social daquela comunidade -, que exerciam o importante papel de alicerçar as estruturas da produção cultural do grupo através da religião e das festas.

Era comum as baianas de maior peso irem à Bahia tratar de suas coisas de santo e dos negócios de nação, progressivamente centralizados nas casas de candomblé de Salvador, como os negros baianos iam eventualmente à África, voltando com informações e mercadorias. Tia Bebiana e suas irmãs-de-santo Mônica, Carmem do Xibuca, Ciata, Perciliana, Amélia e outras que pertenciam ao terreiro de João Alabá, formam um dos núcleos principais de organização e influência sobre a comunidade. Enquanto as classes populares, em sua minoria proletarizadas, sob a liderança inicial dos anarquistas, se organizam em sindicatos e convenções trabalhistas, grande parte do povão carioca que se desloca do cais para a Cidade Nova, pro subúrbio e a favela, predominantemente negro e mulato, também se organiza politicamente, em seu sentido extenso, a partir dos centros religiosos e das organizações festeiras. Assim são essas negras que ganham respeito por suas posições centrais no terreiro e por sua participação conseqüente nas principais atividades do grupo, que garantem a permanência das tradições africanas e as possibilidades de sua revitalização na vida ampla da cidade. ${ }^{9}$

Tia Ciata (Salvador, 1854 - Rio de Janeiro, 1924) é figura de destacada importância quando o assunto é o samba carioca e a Praça Onze. Ela teve morada definitiva na Rua Visconde de Itaúna, nos arredores da famosa praça.

\footnotetext{
${ }^{8}$ Ibidem, p. 86-87.

${ }^{9}$ Ibidem, p. 94.
} 
[...] Mas a mais famosa de todas as baianas, a mais influente, foi Hilária Batista de Almeida, Tia Ciata, relembrada em todos os relatos do surgimento do samba carioca e dos ranchos, onde seu nome aparece gravado Siata, Ciata ou Assiata.

[...] Em 1876, com 22 anos, chega ao Rio de Janeiro, indo morar inicialmente na rua General Câmara. Tempos depois, se muda por conveniência para as vizinhanças de um dos líderes da colônia baiana no Rio, Miguel Pequeno, marido de d.Amélia do Kitundi, na rua da Alfândega, 304.

[...] Com a morte de tia Bebiana, Ciata fica sozinha, sua mudança para a casa de Visconde de Itaúna simboliza a passagem do desfile e de todo o "pequeno carnaval", o grande carnaval da gente pequena, para a Praça Onze. ${ }^{10}$

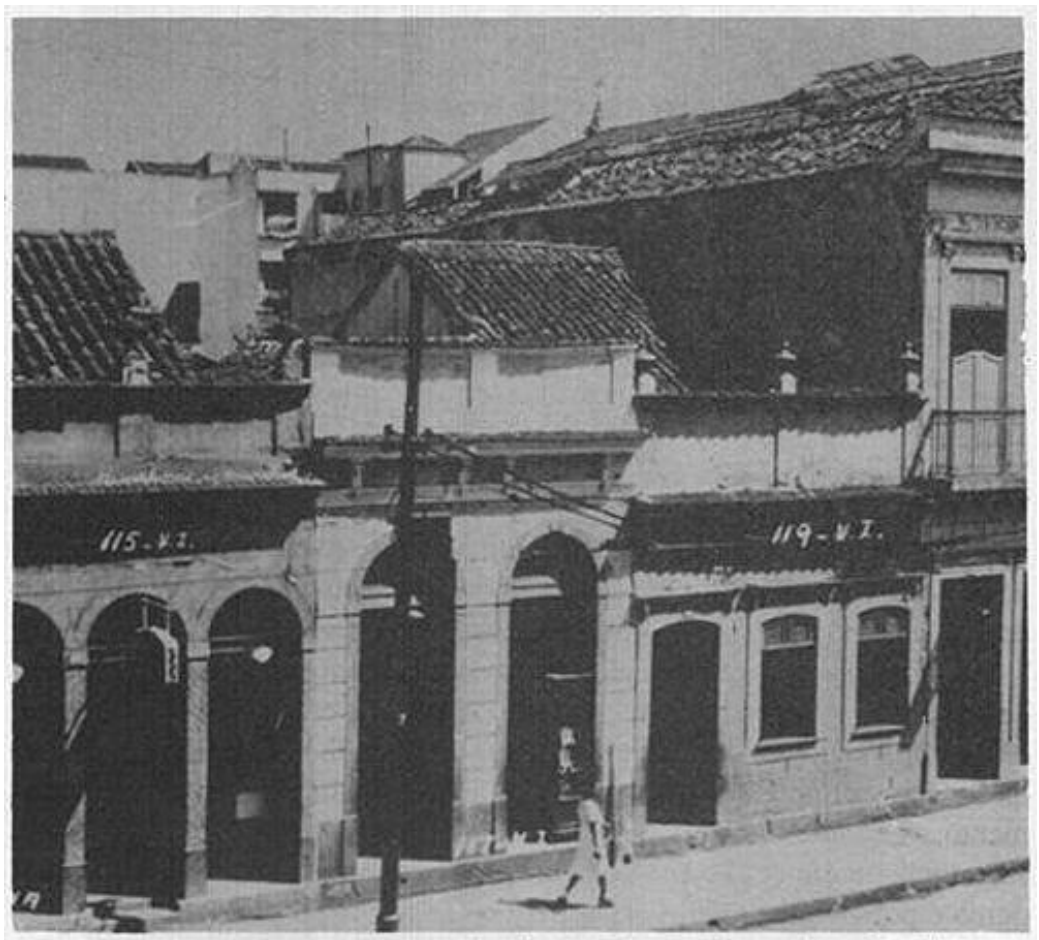

Trecho da rua Visconde de Itauina, em 19 de julho de 1941, pouco antes de ser demolido para a abertura da avenida Presidente Vargas, inaugurada em 1944. Único documento fotográfico da casa de Tia Ciata, assinalada pelo $n^{\circ} 119$. (Embora os livros que tratam do assunto indiquem o $n^{\%} 117$, a descriçäo dos que freqilentavam a casa corresponde ao 119.) (AGCRJ.Fotógrafo não identificado).

Sergio Cabral corrobora os fatos através de sua pesquisa sobre o surgimento do samba carioca:

As primeiras formas do samba carioca foram geradas pela comunidade negra do Centro da cidade, responsável também pelas novidades carnavalescas apresentadas pelos ranchos, como as

\footnotetext{
${ }^{10}$ Ibidem, p. 101.
} 
alegorias, as orquestras, o abre-alas e os "tenores" - cantores de vozes potentes e que eram responsáveis pelos solos das músicas cantadas. $\mathrm{O}$ radialista e pesquisador Almirante (Henrique Foreis Domingues) apontou a casa de Tia Ciata, na Rua Visconde de Itaúna, perto da Praça Onze, como o local de nascimento do samba do Rio de Janeiro, porque lá se reunia uma das duas elites da comunidade negra, formada por criadores que quase sempre tocavam algum instrumento musical uns, por sinal, com grande maestria (a outra elite era integrada pelos trabalhadores do porto, onde a remuneração - assim como sua organização sindical - era bem superior à dos proletários de um modo geral). ${ }^{11}$

A casa de Tia Ciata era frequentada pela mais variada gente, criando encontros

entre a elite da zona sul, a elite baiana, o povo da região, artistas, jornalistas e intelectuais como Mario de Andrade, que descreveu o terreiro de tia Ciata em um dos capítulos de Macunaíma. Esse contato tão diverso era motivado por algumas razões:

Além da venda dos doces, Ciata passa também a alugar roupas de
baiana feitas pelas negras com requinte para os teatros, e no Carnaval
para as cocotes chiques saírem nos Democráticos, Tenentes e
Fenianos, as associações carnavalescas da pequena classe média
carioca.
[...] Com o comércio de roupas, muita gente de Botafogo vai até a
casa de Ciata. Torna-se folclórico para alguns assistir a um pagode na
casa da baiana, onde só se entrava através de algum conhecimento.
Do mesmo modo passa a interessar à alta sociedade da época a
consulta com os "feiticeiros" africanos, como eram estereotipados
aqueles ligados aos cultos negro-brasileiros (vide o episódio com o
presidente Wenceslau Brás, em que Ciata cura-lhe a perna), e mesmo
a frequiência aos candomblés, mais fechados à curiosidade de
estranhos. A partir dos conhecimentos do marido e de seu prestígio no
meio negro, reconhecido mesmo fora dele, Ciata começa a manter
relações com gente do outro lado da cidade [...].
Enfim, era necessário aprender a se relacionar de alguma maneira com
os brancos, ter aliados, conhecer gente de outras classes, como os
jornalistas pioneiros que cobriam nas páginas secundárias dos jornais
os acontecimentos das ruas que ganhavam algum destaque nas
proximidades do Carnaval. ${ }^{12}$

O olhar de Arthur Ramos e a forma com que ele descreve o Carnaval da Praça

Onze refletem essa "curiosidade folclórica" em observar a cultura ali manifestada.

${ }^{11}$ Cabral, Sérgio. op. cit., p. 32.
${ }^{12}$ Moura, Roberto. op. cit., p. 101. 
Inegavelmente, os personagens desse importante capítulo da historia brasileira tinham consciência de sua origem e, como vimos, as tradições vinculadas ao continente africano e preservadas pelas Tias conviviam naturalmente com a realidade do cotidiano carioca. A interpretação dessa realidade acaba por tomar, não poucas vezes, os rumos do folclore, estereotipando os personagens centrais daquele novo carnaval; não obstante, seu testemunho é rico em detalhes e acrescenta-nos um olhar vivo sobre os tempos daquele impressionante festejo. No último capítulo do livro O folclore negro no Brasil, Ramos descreve o que, segundo seus estudos, seria a permanência do "inconsciente folclórico" dos brincantes descendentes de africanos nos festejos carnavalescos da mitológica Praça Onze:

Perseguido pelo branco, o negro no Brasil escondeu as suas crenças nos terreiros das macumbas e dos candomblés. $\mathrm{O}$ folclore foi a válvula pela qual ele se comunicou com a civilização branca, impregnando-a de maneira definitiva. As suas primitivas festas cíclicas de religião e magia, de amor, de guerra de caça e pesca... Entremostraram-se assim disfarçadas e irreconhecíveis. O negro aproveitou as instituições aqui encontradas e por elas canalizou o seu inconsciente ancestral: nos autos europeus e ameríndios do ciclo das janeiras, nas festas populares, na música e na dança, no carnaval...

Principalmente no carnaval. Todos os anos a Praça Onze de Junho, no Rio de Janeiro, recebe a avalanche dessa catarse coletiva. Ali, o carnaval é apenas um pretexto. Porque todo um mundo de sentimentos, de crenças e de desejos, não tolerados na vida comum, desperta de um trabalho surdo de recalques contínuos. O carnaval é uma visão espectral da cultura de um grupo humano. Os civilizados explodem a sua vida instintiva reprimida. Mas o primitivo apenas se mostra na sua espontaneidade de origem. É o caso da Praça Onze, conglomerado de todo um inconsciente ancestral. Ali se reúnem, periodicamente, velhas imagens do continente negro, que foram transplantadas para o Brasil: o monarca das selvas africanas, reis, rainhas e embaixadores, totens, feiticeiros e xamãs, homens-tigres e homens-panteras, griots, menestréis e bardos negros, pais-de-santo, antepassados, pais e adolescentes em iniciação ritual...

$\mathrm{O}$ folião das avenidas passa por aquele lugar e não compreende o que vê. Mas o etnógrafo vai registrando.Cerimônias de guerra e caça:lá estão negros que se degladiam, terçando armas, brandindo lanças, dançando pantomimas imitativas... Danças e desfiles totêmicos: os ranchos, os clubes... embaixadas e desfiles régios: os cordões, os antigos festejos do ciclo dos cucumbis... Fragmentos mágicoreligiosos: os cantos de macumba, as invocações, os ensaios preliminares de possessão... A música e a dança: os instrumentos de 
percussão, os cânticos, a estilização primitiva do samba, as escolas de samba... ${ }^{13}$

Para Arthur Ramos, as reminiscências atribuídas por ele a um "inconsciente folclórico ancestral" tomavam corpo na forma de atavismos, justificando a permanência, segundo o autor, do que considerava ser uma "estrutura primitivo-indiferenciada" onde o folclore seria sua expressão máxima, descartando o trânsito, as trocas de informação e o plano consciente das comunidades em manter as antigas manifestações inserindo-as em novas realidades sociais:

É uma fantasmagoria. Num tempo absolutamente restrito, assistimos à recapitulação de toda uma vida coletiva. Instituições que se fragmentam se esboroam e se diluem. Os seus remanescentes são recolhidos pela Praça Onze. A Praça Onze é o sensor do inconsciente negro-africano. Todo um trabalho semelhante ao da elaboração onírica (Traumarbeit) encontramos ali: condensações, simbolismos, disfarces, sublimações, derivações [...].

A Praça Onze é a fronteira entre a cultura negra e a branco-européia, fronteiras sem limites precisos, onde se interpenetram instituições e se revezam culturas. Mas a Praça Onze, por sua vez, já é um símbolo de todas as Praças Onze disseminadas pelos focos de cultura negra no Brasil. O negro evadido dos engenhos e das plantações, e das minas, e dos trabalhos domésticos das cidades, e dos mocambos, e das favelas, e dos morros... Vai mostrar nas Praças Onze o seu inconsciente folclórico. Evadido no tempo e deslocado no espaço, o negro realiza então um símbolo. $\mathrm{O}$ inconsciente folclórico é uma síntese do inconsciente ancestral e do inconsciente interpsíquico. É um conteúdo estrutural, um Paideuma. ${ }^{14}$

De acordo com Ramos, o "inconsciente folclórico" seria "uma antiga estrutura indiferenciada, que irrompe na vida dos civilizados na forma de superstições, sobrevivências, valores pré-lógicos, folclore, em suma”. Podemos concluir, portanto, que, para ele, a religião e as manifestações dos grupos baiano e carioca na Praça Onze

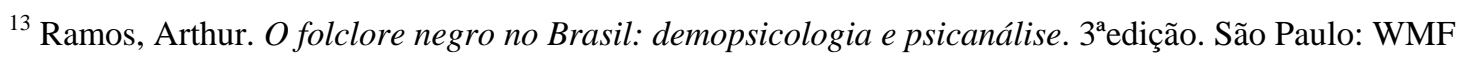
Martins Fontes, 2007, p. 229-231.

${ }^{14}$ Ibidem, p. 230.
} 
eram expressões de origem folclórica que reforçavam o olhar de curiosidade pelo exótico dos visitantes da zona sul carioca.

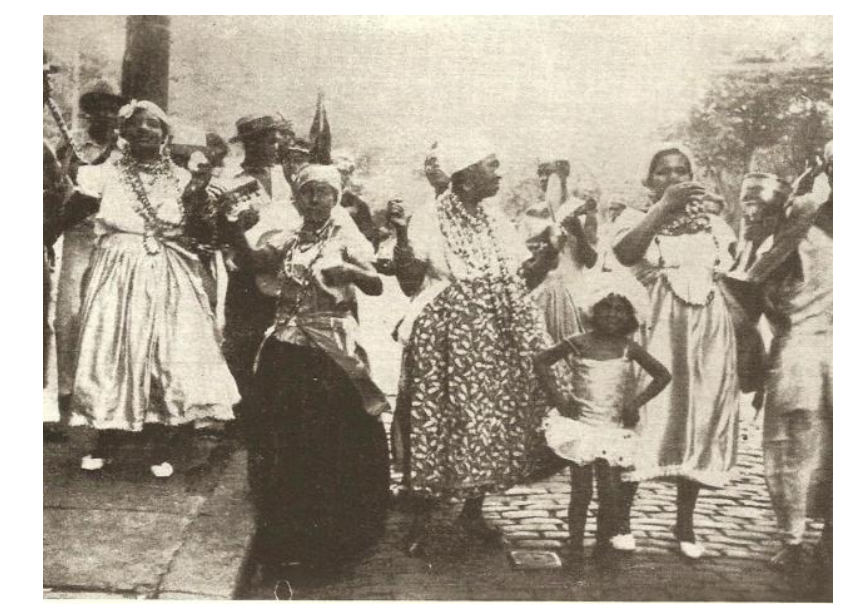

O Carnaval da Praça Onze, em foto do livro de Arthur Ramos.

A despeito de tais olhares, "zonas de contato" entre grupos diferentes aconteciam inevitavelmente, e foi nesse ambiente efervescente que muitos artistas fundamentais para o enredo da história de nosso país desenvolveram suas vidas e produções. O artista Heitor dos Prazeres cresceu nesse mesmo contexto social e, assim como outros, foi educado dentro de um repertório intelectual forjado na casa de Tia Ciata e na Praça Onze. Desde pequeno, ele ali frequentou como se estivesse numa escola, aprendendo na religião e no cotidiano estratégias para suas artes e sua sobrevivência. A trajetória de Heitor demonstra a vocação daquela comunidade em movimentar ideias, disseminar novidades e fomentar invenções a partir de suas ricas vivências. 


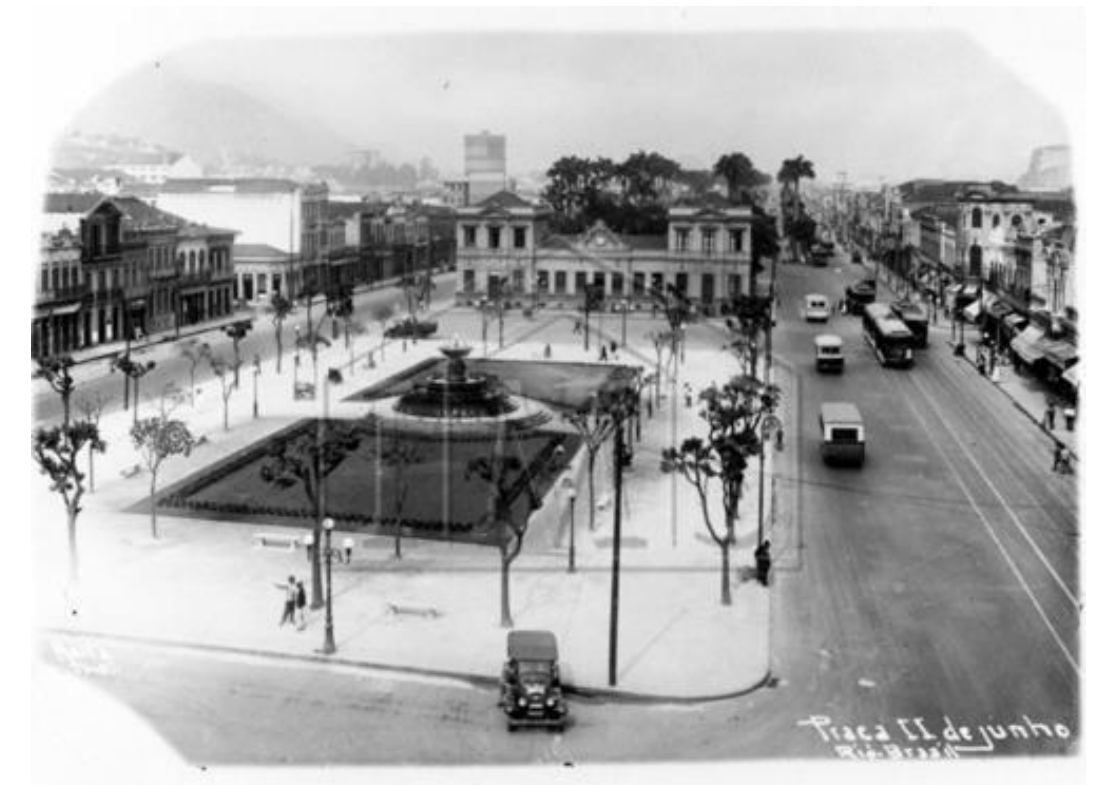

A antiga Praça Onze

Na pequena biografia que traçou sobre Heitor dos Prazeres, Rubem Braga conta um pouco sobre a presença do múltiplo artista na casa de Hilária:

Cresceu entre a Praça Onze e o Mangue, que naquele tempo "era simplezinho" e onde "choromingavam os primeiros choros dos carnavais cariocas" e os "sambas da Tia Ciata". Se o poeta Manuel Bandeira andou em 1910 ouvindo os sambas da Tia Ciata é capaz de se lembrar de um negrinho magro, muito limpo e muito bem vestido, com uma cabeça curiosamente talhada, as orelhas muito miúdas e presas ao crâneo; numa delas pendia o cigarro aceso enquanto tocava cavaquinho, ou na hora de esticar o braço para aceitar uma dose de cachaça. ${ }^{15}$

Os ofícios ensinados no início da vida de Prazeres foram aprendidos por ele por meio da transmissão compartilhada com membros mais velhos da comunidade, assim como fora sua vivência religiosa, corporal e musical na casa de tia Ciata. Essa transmissão, como já vimos, mantinha a tradição existente em diversas cidades brasileiras, em que grupamentos de forros ou de escravos de ganho se especializavam nas mais variadas profissões:

"Sou do tempo da aprendizagem, que agora é difícil. Quem sabia mais ensinava o que viria a gerar a formação de grupamentos de pessoas em torno de certos ofícios que se tornam tradicionais no grupo baiano na

\footnotetext{
${ }^{15}$ Braga, Rubem. Três Primitivos. Ministério da Educação, 1953, p. 10-11.
} 
Praça Onze, Zona do Peo, da Saúde". [...] "fui um dos melhores naquela época, vivia na Praça Onze". ${ }^{16}$

Com a morte de Tia Ciata, em 1924, "vieram dias difíceis" e, apesar da união familiar até a década de trinta, o núcleo central, sua casa e suas festas encerraram um ciclo da história carioca.

Heitor começou a pintar já na maturidade, incentivado por amigos. Com sua força expressiva e autobiográfica, representou em sua pintura tudo o que viu e viveu nos bares, terreiros, ruas e festas do carnaval, deixando para a posteridade a história da gente da Cidade Nova. Segundo ele, até o que ouvira falar sobre a roça, sobre os trabalhos no eito, foi tema de suas obras.

O mangue, os trabalhadores, as danças, as festas, as mulheres, todo um universo costumeiramente retratado pelo outro, captado por viajantes estrangeiros, ou por artistas estranhos àquele lugar, recebeu nova interpretação pelos olhos do sambista. Essa capacidade de realizar uma crônica de sua existência é justamente um dos elementos marcantes do viço de sua invenção. A empatia com sua origem, com sua história, enfim, com sua comunidade, foi contada pelo próprio artista no fim de sua vida:

Eu sou Heitor dos Prazeres. Heitor dos Prazeres é o meu nome. Este prazer que eu tenho no nome é o prazer que eu divido com o povo. Este povo com quem eu reparto este prazer. Este povo que sofre, este povo que trabalha, este povo alegre que eu compartilho a alegria desse povo. A alegria deste povo, o sofrimento deste povo é o que me obriga a trabalhar. É o que me faz transportar para a tela o sofrimento do povo. Este povo que sou eu, um homem do povo. Não há nada mais sublime do que a massa humana. O povo é a massa humana, é a voz do sangue, o povo é a carne humana, o povo é o aconchego, o povo é tudo. Eu para o povo represento um pedaço. Eu sou o ovo e o povo é a chocadeira. ${ }^{17}$

\footnotetext{
${ }^{16}$ Heitor dos Prazeres, As vozes desassombradas do museu, 1966, MIS/RJ. In: Moura, Roberto. Tia Ciata e a Pequena África no Rio de Janeiro, Coleção Biblioteca Carioca, Funarte, Rio de Janeiro, 1983, p. 69.

${ }^{17}$ Transcrição de documentário de Antonio Carlos da Fontoura, 1965.
} 


\section{A CRÍTICA: PRIMITIVO, NAÏF, INGÊNUO}

A busca da compreensão a respeito dos vestígios da produção artística de origem africana - e, mais tarde, de origem afro-brasileira - e das transformações de conceitos e denominações para essas manifestações no Brasil remontam aos escritos de Nina Rodrigues, um dos precursores das Ciências Sociais no país.

[...] A releitura de Silvio Romero, Euclides da Cunha, Nina Rodrigues é esclarecedora na medida em que revela esta dimensão da implausibilidade e aprofunda nossa surpresa, por que não certo malestar, uma vez que desvenda nossas origens. A questão racial tal como foi colocada pelos percussores das Ciências Sociais no Brasil adquire na verdade um contorno claramente racista, mas aponta para além desta constatação, um elemento que me parece significativo e constante na história da cultura brasileira: a problemática da identidade nacional. ${ }^{18}$

Em nossa pesquisa, privilegiamos o material produzido por Nina Rodrigues

(Vargem Grande, 4 de dezembro de 1862 - Paris, 17 de julho de 1906) pelo fato de este ser o primeiro pesquisador no Brasil a ter como objeto de estudo as tradições africanas e seus efeitos em nosso país. Não por coincidência, este autor escreveu a partir dos fins do século XIX, período que coincide com a abolição da escravidão no país e, consequentemente, como porta-voz oficial de uma elite racista que detinha o poder e tomava decisões em relação ao destino dos negros libertos, demonstrando apreensão em relação à presença do povo africano e de seus descendentes em terras brasileiras. Esta preocupação é visível no texto de Sylvio Romero usado como prefácio para o livro de Rodrigues, Os Africanos no Brasil, publicado postumamente:

É uma vergonha para a sciencia do Brasil que nada tenhamos consagrado de nossos trabalhos ao estudo das línguas e das religiões africanas. [...] nós que temos o material em casa, que temos a África em nossas cozinhas, como a América em nossas Selvas e a Europa em

\footnotetext{
${ }^{18}$ Ortiz, Renato. Cultura brasileira e identidade nacional. São Paulo: Brasiliense, 2006, p. 13.
} 
nossos salões, nada havemos produzido neste sentido!É uma desgraça. [...] O negro não é só uma machina econômica; elle é antes de tudo, e máo grado sua ignorância, um objeto de sciencia.

Apressem-se os especialistas, visto que os pobres moçambiques, benguelas, monjolos, congos, cabindas, caçangas... vão morrendo. ${ }^{19}$

Dentre os assuntos abordados no livro, temos um capítulo inteiramente dedicado às "Bellas-Artes nos Colonos Pretos", em que o autor analisa a linguagem, a dança, a música, a pintura e a escultura. No capítulo seguinte, ele discorre sobre "sobrevivências totêmicas", descrevendo festas populares e folclore; entre outros assuntos, este capítulo aborda "sobrevivências africanas em festas populares outras, o carnaval, a dança dos Congos, os Cacumbys”.

O discurso elaborado por Nina Rodrigues “possibilitou o desenvolvimento de escolas posteriores, como por exemplo, a escola de antropologia brasileira, que, vinculada aos ensinamentos de Nina Rodrigues, adquire com Arthur Ramos a configuração definitiva de ciência da cultura". ${ }^{20}$ Um dos autores que posteriormente também participou do desenvolvimento deste pensamento foi Gilberto Freyre.

Destacamos a importância de obras de autores europeus, precursores dos estudos das questões raciais, que contribuíram para o desenvolvimento das teorias dos pesquisadores brasileiros:

Ao se referir ao declínio da hegemonia do romantismo de Gonçalves Dias e José de Alencar, que podemos situar em torno de 1870, Sílvio Romero arrola uma lista de teorias que teriam contribuído para a superação do período romântico. Dentre elas, três tiveram um impacto real junto á intelligentsia brasileira, e de certa forma delinearam os limites no interior dos quais toda a produção teórica da época se constitui: o positivismo de Comte, o darwinismo social, o evolucionismo de Spencer. Elaboradas na Europa em meados do século XIX, essas teorias distintas entre si, podem ser consideradas sob um aspecto único: o da evolução histórica dos povos. ${ }^{21}$

\footnotetext{
19 Romero, Sylvio. Estudos sobre a Poesia Popular do Brasil. Rio de Janeiro, 1888, p. 10-11 In: Rodrigues, Nina. Os Africanos no Brasil. São Paulo: Cia. Editora Nacional, 1932, p. 5-6.

${ }^{20}$ Ortiz, Renato. op. cit, p. 14.

${ }^{21}$ Ibidem.
} 
No que tange à questão da adoção da teoria da evolução dos povos, cabe aqui, para compreendermos termos que serão utilizados pelos críticos que escreveram sobre a obra de Heitor, aprofundarmos de que modo foi trabalhada a questão da "evolução histórica dos povos".

A proposta do evolucionismo era "encontrar um nexo entre as diferentes sociedades humanas ao longo da história: aceitando como postulado que o simples (povos primitivos) evolui para o mais complexo (sociedades ocidentais)", esta análise do progresso das civilizações concedeu, no século XIX, garantias políticas para a consciência do poderio europeu sobre as demais civilizações, o que foi consolidado com a expansão do poder por meio do capitalismo. ${ }^{22}$

Apesar de trabalharem embasados nas teorias citadas, os intelectuais brasileiros defrontam-se dentro dessa lógica com a questão inevitável do atraso brasileiro em relação às nações europeias, obrigando-os, segundo Ortiz, a investir na possibilidade de "o Brasil se constituir como um povo, isto é, como nação" levando aos estudos diferenciados em relação aos autores europeus sobre“o caráter nacional” para chegar a formação de um "estado nacional". Para particularizar seus estudos, o pensamento brasileiro seguiu em direção à raça e ao meio, evoluindo mais tarde, principalmente a partir de Gilberto Freyre (1900-1967), para a análise da cultura. Freyre, entretanto, não abandonou questões raciais, analisando mestiçagens entre os diferentes povos no Brasil:

Foi o estudo de antropologia sob a orientação do professor Boas que primeiro me revelou o negro e o mulato no seu justo valor - separados dos traços de raça os efeitos do ambiente ou da experiência cultural. Aprendi a considerar fundamental a diferença entre raça e cultura; a discriminar entre os efeitos de relações puramente genéticas e os de influências sociais, de herança cultural e de meio. ${ }^{23}$

\footnotetext{
${ }^{22}$ Ibidem.

${ }^{23}$ Freyre, Gilberto. Casa Grande \& Senzala: formação da família brasileira sob o regime patriarcal. $51^{\mathrm{a}}$ edição. São Paulo: Global, 2008, p. 32.
} 
Além da questão da identidade nacional - que, em Freyre, evolui para um sentido mais positivo em relação ao desenvolvimento do país, apostando na mestiçagem como uma qualidade do brasileiro -, voltemos à importância do estudo precursor de Nina Rodrigues e seus desdobramentos. A pesquisa voltada especificamente para a produção das artes plásticas de matriz africana apenas se desenvolveu após cerca de trezentos anos de escravidão da população oriunda de diversas regiões do continente africano:

Durante quase três séculos, essa arte, seguindo o passo de sua matriz africana, ficou totalmente ignorada, não apenas do grande público, mas também do mundo erudito historiador, crítico de arte, sociólogo ou antropólogo. Foi graças ao trabalho pioneiro de Nina Rodrigues que os primeiros trabalhos de arte afro-brasileira foram publicados em 1904, na revista Kosmos.

Em 1949, Arthur Ramos analisa alguns exemplares por ele coletados em 1927 nos candomblés da Bahia. Em 1968, Clarival do Prado Valladares publica dados sobre as peças mais antigas encontradas pela polícia em Alagoas e que foram apreendidas pela polícia em 1910, peças essa utilizadas nos cultos afro-brasileiros nas últimas décadas do século XIX. ${ }^{24}$

Esses três autores, portanto, são fundamentais para compreendermos a pesquisa e a interpretação dos vestígios culturais africanos incorporados pela cultura brasileira, que rompem o silêncio em relação ao período escravocrata:

[...] nada se tem a respeito das populações africanas: o período escravocrata é um longo silêncio sobre as etnias negras que povoam o Brasil. Em sua bricolage nacional, o romantismo pode ignorar completamente a presença do negro. A situação se transforma radicalmente com o advento da Abolição. Como fato político, a Abolição marca uma nova ordem onde o negro deixa de ser mão-deobra escrava para se transformar num trabalhador livre. Evidentemente ele será considerado pela sociedade um cidadão de segunda categoria; no entanto em relação ao passado tem-se que a problemática racial torna-se mais complexa na medida em que um novo elemento deve obrigatoriamente ser levado em conta. $\mathrm{O}$ negro aparece assim como fator dinâmico da vida social e econômica

\footnotetext{
${ }^{24}$ Munanga, Kabengele. “Arte afro-brasileira: o que é afinal?” In: Catálogo Mostra do Redescobrimento Brasil 500 é mais. São Paulo: Associação Brasil 500 anos Artes Virtuais, p. 98-111.
} 
brasileira, o que faz com que, ideologicamente sua posição seja reavaliada pelos intelectuais e produtores de cultura. ${ }^{25}$

Neste contexto de liberdade, o indivíduo ex-escravo e seus descendentes reformularam seus papéis dentro da sociedade brasileira, dando espaço para o interesse e para o desenvolvimento dos estudos dos autores citados. O pioneirismo de Nina não o impediu de "ter buscado explicar, em bases ditas científicas, a inferioridade do elemento africano e sua incapacidade inata para a civilização". ${ }^{26} \mathrm{Na}$ esteira de seu pensamento, outros intelectuais desenvolveram estudos como o Folclore negro do Brasil, de Arthur Ramos, que teve a primeira edição publicada em 1935.

Eu não me canso, em meus estudos atuais sobre o negro brasileiro, de chamar a atenção para os trabalhos de Nina Rodrigues, [...], o Congresso (afro-brasileiro) de Recife (1934) assinalou nova fase das pesquisas sobre o negro brasileiro, mas será injustiça desconhecer o grande mérito da escola de Nina Rodrigues, revelou às gerações de hoje os primeiros estudos científicos sobre a questão, agora continuada pelos seus discípulos. ${ }^{27}$

O desenvolvimento dessas pesquisas lançou olhar para os afro-descendentes que a essa altura expandiam suas possibilidades de expressão e de trabalho através da arte. O samba é um exemplo evidente disso, tendo alcançado no Rio de Janeiro a possibilidade de ser gravado e comercializado. Convém, portanto, considerarmos o empenho daquele grupo em formular uma arte que provocasse interesse .

A partir das décadas de 30 e 40(do século XX), a arte afro-brasileira, reduzida ao espaço das casas de culto, começa a sair da clandestinidade. Seus artistas abandonam o anonimato e alguns deles começam a trabalhar dentro do conceito das chamadas artes "popular" e "primitiva", encorajados pelo movimento modernista e pela busca do nacionalismo.

Estímulos científicos e culturais tais como o os dois congressos organizados respectivamente em Recife (1934) e em Salvador (1937), duas missões folclóricas enviadas ao Norte e Nordeste por Mário de

\footnotetext{
${ }^{25}$ Ortiz, Renato. op. cit.,. p. 19.

${ }^{26}$ Ferreira, Ligia F. Prefácio de Ramos, Arthur. O folclore negro do Brasil: demopsicologia e psicanálise. $3^{\mathrm{a}}$ edição. São Paulo: WMF Martins Fontes, 2007, p. 14.

${ }^{27}$ Ibidem.
} 
Andrade em 1937-38 para coletar material e outros estudos africanistas vão contribuir para o reaparecimento de artistas e temas afro-brasileiros nas artes plásticas. ${ }^{28}$

Na realidade, os artistas não reapareceram, apenas permaneceram relegados a uma marginalidade, cavando espaços e por essa agência, os intelectuais acabaram por estabelecer contato com suas manifestações, divulgando sua arte para além de seu espaço de convívio.

Apesar da evolução do pensamento de Nina através desses autores, que modificaram sua ótica e optaram por abandonar a ideia de degenerescência do elemento africano - o que acabou por se desenvolver no otimismo da democracia racial de Freyre -, a produção artística daquele grupo permanece no lugar relegado a ela: primitivo ou popular.Além disso o mito da democracia racial brasileira, que ecoa até os dias de hoje serve para mascarar o racismo brasileiro ao longo dos anos em nosso país.

Segundo Stuart Hall, estudioso da diáspora negra desencadeada pelo processo de escravidão dos africanos para as Américas e de seus desdobramentos pós-abolição, os conceitos "popular” e "primitivo" são arriscados e movediços. Em relação à noção de popular, Hall acredita que:

[...] há uma luta contínua e incessante irregular e desigual, por parte da cultura dominante, no sentido de desorganizar e reorganizar constantemente a cultura popular; para cercá-la e configurar suas definições e formas dentro de uma forma mais abrangente de formas dominantes. Há pontos de resistência e também momentos de superação. Essa é a dialética da luta cultural. ${ }^{29}$

A dialética desta "luta cultural", de acordo com Hall, ocorre em uma "tensão contínua" com a "cultura dominante", tornando-se um "processo pelo qual algumas

\footnotetext{
${ }^{28}$ Munanga, Kabengele. “Arte afro-brasileira: o que é afinal?” In: Catálogo Mostra do Redescobrimento Brasil 500 é mais. São Paulo: Associação Brasil 500 anos Artes Virtuais, p. 98-111.

${ }^{29}$ Hall, Stuart. Da diáspora: identidades e mediações culturais. Org. Liv Sovik. Belo Horizonte: UFMG, 2003, p. 239.
} 
coisas são ativamente preferidas para que outras possam ser destronadas". ${ }^{30}$ Assim foi, por exemplo, o caso do romantismo brasileiro, com a figura do herói indígena cambiando para a exaltação da herança cultural africana. Obviamente, entretanto, essa preferência não determina a troca de papéis entre quem está no poder e quem permanece à margem dele.

Verificamos esse fato na denominação frequentemente usada para definir as expressões culturais vinculadas à tradição, ou que contenham resquícios de origem africana: o que vem do povo e o que é primitivo (a respeito do popular, já comentamos anteriormente). Stuart Hall, mais adiante, analisa o sentido do primitivo citando o crítico de arte Hal Foster, que, para nós, é coerente com as definições de autores brasileiros:

Hal Foster escreve: "O primitivo é um problema moderno, uma crise na identidade cultural", daí a construção modernista do primitivismo, o reconhecimento fetichista e a rejeição da diferença do primitivo. Mas essa resolução é somente uma repressão; o primitivo detido no interior de nosso inconsciente político retorna como um estranho familiar, no momento de seu aparente eclipse político. Essa ruptura do primitivismo, administrada pelo modernismo, torna-se outro evento pós-moderno. Essa administração é certamente evidente na diferença de não produzir diferença alguma e que marca o surgimento ambíguo da etnicidade no âmago do pós-modernismo global. Mas não pode ser só isso, pois não podemos esquecer como a vida cultural, sobretudo no Ocidente e também em outras partes, tem sido transformada em nossa época pelas vozes das margens. ${ }^{31}$

A margem, neste caso, seria a cultura de origem africana, reconhecidamente criativa pelos estudiosos, e necessária para o estabelecimento do Brasil como nação:

Um padrão recorrente emerge: o "de cima" tenta rejeitar e eliminar o que vem "de baixo" por razões de prestígio e status e acaba descobrindo que não só está de algum modo, frequentemente dependente desse baixo - Outro [...] mas também o de cima inclui simbolicamente o de baixo como constituinte primário de sua própria vida de fantasia. O resultado é uma fusão móvel e conflitiva de poder, medo e desejo na construção da subjetividade: uma dependência psicológica de precisamente aqueles outros que estão sendo rigorosamente impedidos e excluídos no nível de vida social. É por

\footnotetext{
${ }^{30}$ Ibidem, p. 241.

${ }^{31}$ Ibidem, p. 320.
} 
essa razão que o que é socialmente periférico é simbolicamente central... ${ }^{32}$

Assim como em Casa Grande e Senzala Gilberto Freyre aposta na miscigenação entre portugueses com índios e negros, a posição de cada elemento a ser miscigenado não ocorre em nível de igualdade. O colonizador português foi o protagonista e, através de sua agência, garantiu a expansão de suas colônias; "quanto à miscibilidade, nenhum povo colonizador, dos modernos, excedeu ou sequer igualou nesse ponto aos portugueses". ${ }^{33}$

Em relação à mulher indígena, segundo Freyre, “por qualquer bugiganga ou caco de espelho estavam se entregando de pernas abertas aos caraíbas gulosos de mulher”. Ao considerar a mulher branca, a mestiça e a negra, Freyre segue analisando o papel sexual de cada uma, afirmando que

com relação ao Brasil, que o diga o ditado: "Branca para casar, mulata para f..., negra para trabalhar", ditado em que se sente ao lado do convencionalismo social da superioridade da mulher branca e da inferioridade da mulher preta a preferência sexual pela mulata. ${ }^{34}$

Embora os portugueses tenham se misturado aos povos que pretendiam dominar, utilizando a denominação de arte primitiva para lidar com a crise de identidade na arte europeia dos fins do século XIX e o início do século XX, este elemento "primitivo", por mais positivo que fosse para a sociedade europeia, não o seria para as sociedades denominadas primitivas. Isso as condenaria ao eterno "atraso" em relação ao ocidente, haja vista tratar-se apenas de um apêndice a ser utilizado como alternativa a esta crise:

\footnotetext{
${ }^{32}$ Stallybrass, Peter; White, Allon. The Politics and Poetics of Transgression. In: Hall, Stuart. Da diáspora: identidades e mediações culturais. Org. Liv Sovik. Belo Horizonte: UFMG, 2003, p. 329-330.

${ }^{33}$ Freyre, Gilberto. op. cit., p. 70-72.

${ }^{34}$ Ibidem.
} 
Se se pensa que a pintura de Cézanne era uma súmula da cultura figurativa européia, o problema se coloca nos seguintes termos: como superar o limite histórico da pintura de Cézanne, como alargar seu horizonte? $\mathrm{O}$ universalismo de Matisse não era uma solução, não se tratava de transfigurar a realidade, mas de transformá-la em sua estrutura. Não havia qualquer sentido em acolher os entalhadores negros de máscaras e fetiches no paraíso da arte universal; o necessário era resolver dialeticamente a contradição pela qual as duas soluções opostas, oferecidas por uma "civilidade extrema" e por uma "barbárie extrema", apareciam como igualmente válidas no plano estético e no plano histórico, ou melhor, ligadas entre si numa estreita alternativa dialética. ${ }^{35}$

$\mathrm{Na}$ arte europeia, nesta busca pela dialética, "Picasso não estava sendo o primeiro a descobrir a escultura negra; já havia os fauves e os expressionistas, seguindo nos rastros do exotismo e primitivismo de Gauguin". ${ }^{36}$ O pintor Gauguin personifica "o artista que se põe contra a sociedade de sua época para reencontrar numa natureza e entre pessoas não corrompidas pelo progresso a condição de autenticidade e ingenuidade primitivas, quase mitológicas", almejando "a flor da poesia, agora exótica, que é destruída pelo clima da Europa industrial”. ${ }^{37}$

Além deste olhar para fora da Europa, concomitantemente aos desdobramentos da ideia do exótico e do primitivo, "passa-se ao interesse pelo artista inculto, ingênuo, popular, devendo esta última definição ser sumariamente excluída, devido à longa série dos naïfs que despertam o interesse de uma sociedade saturada de intelectualismo". ${ }^{38}$ Segundo Argan, o "fundador" desse tipo de arte seria Henri Rousseau (1844-1910), "um fiscal de impostos que, aos quarenta anos, deixou seu emprego para se dedicar à pintura".

Apesar de afirmar que Rousseau manifesta frente arte a "ilimitada admiração do ignorante, do primitivo", Argan sustenta que, na verdade, "ele não era inculto, e sim

\footnotetext{
35 Argan, Giulio Carlo. Arte Moderna. Tradução: Denise Bottmann e Federico Carotti. São Paulo: Companhia das letras, 1992, p. 426.

${ }^{36}$ Ibidem, p. 426.

${ }^{37}$ Ibidem, p. 130.

${ }^{38}$ Ibidem, p. 134.
} 
um autodidata que certamente carecia de cultura profissional" em consequência de seu surgimento. De acordo com o autor, Henri Rousseau foi automaticamente "adotado por artistas e literatos que combatiam a cultura preferida pela alta burguesia parisiense: de Signac a Picasso, de Jarry a Apollinaire".

Na opinião de Argan, o papel do artista Rousseau, que é contemporâneo ao período das viagens de Gauguin para o Taiti e de Rimbaud para a África, favorece o interesse pelo surgimento de um artista "virgem e primitivo" em Paris, tal e qual seriam as culturas das terras longínquas buscadas pelo pintor e pelo escritor citados:

Logo mais, crer-se-á descobrir a arte pura na escultura negra: o "caso Rousseau" é o antecedente direto da crise cultural que levará Picasso a refazer Les demoiselles d'Avignon (1907) segundo o modelo negro.[...] Sem dúvida, numa época em que se falava apenas em progresso, a pintura de Rousseau só poderia se mostrar assustadoramente regressiva: revela não tanto seu próprio primitivismo, e sim o de uma civilização que, convencida de possuir a chave da verdade, afundava-se cada vez mais na superstição dos símbolos, mitos e da magia.Gauguin, no Taiti, via os mitos dos "bárbaros" com os olhos do parisiense em férias; Rousseau em Paris, vê os mitos da civilização moderna com os olhos do primitivo deslocado numa sociedade evoluída. ${ }^{39}$

Em nosso país, tivemos um processo semelhante, localizado historicamente na descoberta da obra de Cardozinho (1861-1942) por Fujita e Portinari, em 1932. O pintor Cardozinho foi considerado o Rousseau brasileiro. ${ }^{40}$ Rubem Braga escreveu sobre ele, definindo-o não como um pintor, mas sim como "um fazedor de quadros". Cardozinho começou a pintar aos 70 anos, já aposentado; autodidata, utilizava em seu processo criativo imagens de cartazes e fotografias de revistas velhas e de jornais para pintar suas figuras. Por isso, de acordo com Braga, ele não tinha "qualquer imaginação plástica" e,

\footnotetext{
${ }^{39}$ Ibidem, p. 135-136.

${ }^{40}$ Cavalcanti, Carlos. Heitor dos Prazeres, Pintura. Catálogo de exposição do MAM, abril de 1961, Arquivo Wanda Svevo.
} 
desta forma, distanciava-se dos verdadeiros artistas devido ao fato de não ter "a sabedoria sem a qual não se faz grande arte". ${ }^{41}$

Em um artigo da década de 60 do século XX, Clarival do Prado Valladares, um dos autores importantes para o estudo da presença africana no Brasil, problematizou as consequências do significado do primitivo em terras brasileiras:

A maior frequiência de oportunidades para artistas de cor ocorre quando estes se identificam a determinado tipo de produção, permitido e aplaudido pelo público consumidor. E esta permissão e aplauso se referem à denominada arte primitiva, situada em termos de docilidade, de poeticidade anódina, na dose exata em que a pintura naïf deve comportar-se no conjunto das coleções ou das decorações de ambientes privados de aparente clima cultural. ${ }^{42}$

Nesse mesmo artigo, Clarival analisa a reduzida presença de artistas negros nas artes plásticas em relação a outras manifestações artísticas. Em suas palavras, “a modesta presença de artistas brasileiros negros na atual produção e promoção das chamadas artes plásticas desde que estas se tornaram um atributo de prestígio do estrato social econômico mais elevado, na qual os negros numericamente pouco participam", ${ }^{43}$ combinada com as restrições impostas aos artistas, teria criado o panorama descrito a seguir:

Raros são os artistas pretos e mestiços que se afirmam sob critério crítico mais exigente, pois se conformam às regras do jogo sobre sua produção, que deverá ser ao gosto do consumidor. E este último, muitas vezes requer do "primitivo" ser homem de cor, preto, mulato ou índio, procedente da pobreza afim de que a obra seja autêntica pela origem. Isto não corresponde à generalidade, mas uma das características da elite mandatária, em que os participantes procuram acrescentar, a si mesmos, uma aparência intelectual. ${ }^{44}$

\footnotetext{
${ }^{41}$ Braga, Rubem. Três Primitivos. Ministério da Educação, 1953.

${ }^{42}$ Valladares, Clarival do Prado. O negro brasileiro nas artes plásticas. Cadernos Brasileiros, ano X. Rio de Janeiro, maio-julho, 1968. In: Catálogo Mostra do Redescobrimento - Brasil 500 é mais. São Paulo: Associação Brasil 500 anos Artes Virtuais.

43 Ibidem.

${ }^{44}$ Ibidem.
} 
Não podemos esquecer o que Stuart Hall nos diz a respeito da necessidade do "de cima" pelo "de baixo". O conflito de exclusão e aproximação, que determina lugares socialmente fixos, talvez de fato obrigue esses artistas a aceitar a condição de participar do jogo, adequando-se às regras, mas nem sempre fazendo concessões; aproveitando-se desse espaço para, segundo Hall, tornarem-se "simbolicamente centrais".

Neste contexto, de acordo com Clarival, Heitor dos Prazeres é considerado um dos precursores originais do gênero na pintura nacional, figurando como importante representante dos escassos artistas negros em evidência no referido período.

\footnotetext{
Um capítulo que requer novo estudo é o da presença de artistas negros entre os denominados "primitivos". Heitor dos Prazeres (Rio18981966), Paulo Pedro Leal (Rio, 1894), João Alves (BA, 1906), Waldomiro de Deus Souza (BA, 1944), e José Barbosa da Silva (Olinda, 1948) merecem, para cada um deles um acurado estudo, porque trazem expressiva carga de originalidade, de contexto social, além da potencialidade narrativa dos temas. ${ }^{45}$
}

Dada a importância de Heitor dos Prazeres e o alcance que suas obras tiveram não somente na pintura, mas também em outras áreas de atuação, inúmeras vezes a crítica encarregou-se de interpretar e divulgar suas obras em periódicos, encartes e livros.

O intuito deste capítulo será o de lançar um olhar sobre os escritos produzidos por alguns autores a respeito da produção pictórica de Heitor dos Prazeres. O enfoque da análise terá como destaque a produção crítica de Clarival do Prado Valladares (19181983), Rubem Braga (1913-1990), Carlos Cavalcanti (nascimento e morte com datas desconhecidas ), Carlos Drummond de Andrade (1902-1987).

\footnotetext{
${ }^{45}$ Ibidem.
} 


\subsection{Carlos Cavalcanti}

O crítico de arte, jornalista e desenhista Carlos Cavalcanti foi quem mais escreveu sobre a obra pictórica de Heitor dos Prazeres. Ele é considerado, ao lado de Augusto Rodrigues, o primeiro incentivador da carreira de pintor, estimulando-o a lançar em exposições e mostras o que já produzia para enfeitar as paredes de sua casa:

Jamais havia pintado apenas musicado. Em 1937, perdeu a esposa. Fiquei muito dolente, explica, e comecei a pintar. Viúvo, estava morando num quarto barato na rua do Lavradio, que enchia de desenhos e pinturas a gouache.Dissolvia as tintas de maneira inadequada, às vezes em querosene. Seus temas iniciais foram os mesmos de hoje - cenas do samba, da macumba e do trabalho rural. ${ }^{46}$

Na década de 30, a então capital do país já conhecia os desfiles dos ranchos, as primeiras escolas de samba e o carnaval da Praça Onze, além do incipiente mercado fonográfico e o rádio, que difundiam a cultura musical alimentada nas rodas de bambas, atraindo a curiosidade de intelectuais e jornalistas para o carnaval fora dos clubes de elite e desfiles de corso.

Heitor dos Prazeres, importante personagem do samba carioca, já gozava de notoriedade na música, tendo sido premiado com o primeiro lugar no carnaval de 1932 , como musicista no "concurso oficial", com o samba-canção "Mulher de Malandro". ${ }^{47}$ No Rio, ele morava num quarto da Praça Tiradentes, muito frequentado por jovens universitários que queriam conhecer o universo da cultura afro-brasileira carioca - as rodas de samba, capoeira e jongo, os bambas, os terreiros de candomblé -; entre eles, estavam Carlos Drummond de Andrade, Noel Rosa e Carlos Cavalcanti.

O contato inicial entre o jovem Cavalcanti e a obra do artista deu-se durante as aulas de cavaquinho que ele recebia do então consagrado sambista. Desde o primeiro

\footnotetext{
${ }^{46}$ Cavalcanti, Carlos. op. cit.

${ }^{47}$ Ibidem.
} 
contato com a música de Prazeres, e depois com seus desenhos e pinturas, Cavalcanti percebeu as características que viria a analisar em suas criticas posteriores sobre o artista: originalidade, expressividade, temática e cores das obras. Dessa convivência surgiu seu interesse do jornalista em analisar e produzir material que divulgasse a obra do amigo, além de um franco incentivo e estímulo, criando uma perspectiva de compreensão da pintura de Prazeres como produto de sua vivência.

Como crítico de arte, Carlos Cavalcanti escreveu livros como Arte e Sociedade (1966), Como entender a pintura Moderna (1978) e Dicionário Brasileiro de Artistas Plásticos (1979), além de outros textos para jornais, catálogos de exposições e colaborações para a revista Cadernos Brasileiros, editada por Clarival do Prado Valladares; também participou do Dicionário das Artes Plásticas Brasileiras, organizado por Roberto Pontual em 1969.

Procurando interpretar a opinião de Cavalcanti e suas considerações a respeito da pintura de Mano Lino, citaremos aqui textos publicados por ele em catálogos para as exposições de pintura de Heitor no Museu de Arte Moderna (MAM) do Rio de Janeiro, em 6 de abril, e na Galeria Sistina em São Paulo, com abertura em 27 de novembro, ambos datados do ano de 1961.

No catálogo da exposição realizada em abril de 1961, no MAM, Cavalcanti procurou explicar ao público a origem da arte ingênua, contextualizando-a historicamente:

No princípio deste século, especialmente os Expressionismo e o Fovismo, acentuou-se o interesse pelas criações artísticas, livres de preocupações de natureza intelectual, tanto na técnica como na expressão, e reveladoras das camadas mais profundas e elementares da personalidade. Quando Gauguin dizia pretender voltar não aos cavalos clássicos do Partenon, mas aos rústicos cavalinhos de madeira de sua infância, ou quando Vlaminck afirmava serem suas cores verdadeiros gritos do instinto, estavam revelando novas concepções de pintura, que nos ajudam a compreender o sentido do gosto atual pelo que poderemos chamar a tradução plástica de puros ritmos da vitalidade. 
A espontaneidade lírica e a ausência de intelectualismo das artes das crianças e dos autodidatas passaram a interessar não somente os artistas. Também aos estudiosos dos problemas da criação artística. Os pintores populares ou autodidatas, assim como os artistas negros, desconhecidos e negligenciados durante muito tempo pelos preconceitos acadêmicos, tiveram nos princípios deste século súbita valorização.

Surgiram então os ingênuos pintores de domingo, como os chamam na França. ${ }^{48}$

Nesse texto, ele não diferencia o que poderia ser arte de artistas negros, "arte das crianças", de pintores populares ou autodidatas - também considerados ingênuos. Ao contrário, Cavalcanti investe na ideia de que todos esses casos artísticos pertenceriam à mesma categoria, que, de acordo com ele, seria oposta à dos eruditos com "preconceitos acadêmicos".

Quando se viu, porém, que os elementos permanentes e válidos da criação artística estão mais na área emocional ou instintiva do que na esfera intelectual ou racional do homem, passaram (os ingênuos) à categoria de criadores artísticos autênticos, como as crianças e os selvagens. ${ }^{49}$

Após definir este grupo e suas semelhanças, ele acrescenta em suas considerações a definição do que seriam os primitivos, em sua opinião, fruto de confusão desta primeira categoria (ingênuos, crianças, negros, selvagens e artistas populares). Em um catálogo para uma exposição de Prazeres naquele mesmo ano desta vez na Galeria Sistina, em São Paulo - ele reafirma suas opiniões:

Em outra oportunidade, falando de Heitor dos Prazeres, cuidamos de um equívoco corrente no público e mesmo entre críticos e artistas - a confusão entre ingênuos e primitivos.

Os primitivos - nenhum possuímos na nossa pintura - são dotados de elementarismo, mais instintivos. Expressam de modo imediato os ritmos vitais. São como delegados da natureza. Fundam sua expressão artística em impulsos diretos e profundos, livres de qualquer intelectualismo figurativista. Interpretam mais do que representam.

[...] são mais simbólicos e deformadores, mais sintéticos e de maior sentimento plástico. Manifestam interesse secundário pela figura

\footnotetext{
${ }^{48}$ Ibidem.

${ }^{49}$ Ibidem.
} 
humana e substituem as imagens visuais por esquemas mentais, carregados de simbolismo. ${ }^{50}$

Cavalcanti não chega a enunciar exemplos sobre a criação dos primitivos, ou sobre quais lugares poderíamos apreciar aquela manifestação expressiva. Ele prossegue afirmando:

Sua pintura (dos primitivos) é de superfície, em duas dimensões, cores planas, as cores primevas, e não de profundidade. Possuem concepção geométrica da forma para exprimir, com ilogicismo e ausência de senso estético, idéias e sentimentos e não sensações físicas. ${ }^{51}$

Como vimos em Stuart Hall, em Kabengele Munanga e em Clarival Valladares, os conceitos primitivo e popular - e a estes acrescentamos a noção de “ingênuo" -, são movediços, criando restrições para a análise da produção artística dos grupos "socialmente periféricos". Sendo assim, lançar mão de ideias generalizadas, como a de primitivos que criam "livres de qualquer intelectualismo figurativista", e ao mesmo tempo afirmar que eles "possuem concepção geométrica da forma" associada ao "ilogicismo", parece incoerente. Ao trabalhar com geometrias, dificilmente um artista não pensará sua composição de forma lógica, seja na pintura corporal indígena, nas pinturas rupestres ou na harmonia simétrica de uma figura de Ibejis africanos; seja num ready-made de Duchamp, ou nas Demoiselles de Picasso.

É certo afirmarmos, como vimos em Argan, que a saturação do intelectualismo europeu condicionou a revolta intelectual dos artistas das vanguardas europeias do fim do século XIX e início do século XX, gerando este problema na interpretação de culturas de outras sociedades como sendo meros antípodas da civilização ocidental. Assim, sobrava para elas a pureza da "virgindade do primitivo", gerando a necessidade

\footnotetext{
${ }^{50}$ Cavalcanti, Carlos, Heitor dos Prazeres, Pinturas. Catálogo de exposição da Galeria Sistina, novembro de 1961, Arquivo Wanda Svevo.

${ }^{51}$ Ibidem.
} 
de a arte de vanguarda lidar com "duas soluções opostas, oferecidas por uma civilidade extrema e por uma barbárie extrema".

Carlos Cavalcanti adota a ideia da cultura ingênua autêntica como resposta à falta de identidade do excesso de intelectualismo do artista brasileiro, criticando o distanciamento da pintura e da vida social popular:

[...] os ingênuos autênticos como Heitor dos Prazeres são valores dignos de atenção na nossa pintura contemporânea. Abrem ricas sugestões de autenticidade na linguagem e temática de nossa pintura. [...] nesse nosso país polifônico, nossos modernos tocam quase sempre a flautinha grega de três notas do esteticismo dos estilistas parisienses, como diria Siqueiros.

Por outro lado, europeizamo-nos também quanto ao papel que a pintura deve desempenhar na vida social. Galerias esnobes, quadros custando artificialmente milhões, artistas glorificados no colunismo social, em suma uma pintura cada vez mais de finalidades privadas e domésticas e não públicas, sem repercussão social, e, portanto, educativa. ${ }^{52}$

Assim como a vanguarda europeia procurou encontrar a resposta de sua crise,

a crítica de Cavalcanti aos artistas modernos brasileiros sem nomeá-los reproduziu, de certa forma, a postura tomada por artistas como Gauguin e Picasso na Europa, indicando a solução para o problema da pintura brasileira.

Natural que essas considerações ocorram diante deste artista tão intrinsecamente popular, capaz de sugerir aos plásticos sensíveis, clarividentes e criadores, com os dons de profecia imanentes ao artista, caminhos e pesquisas que nos desviam do colonialismo artístico em que ainda estamos vivendo. ${ }^{53}$

Ao criticar o etnocentrismo, Cavalcanti não foge à regra da oposição entre o popular e o erudito. Ele insiste em interpretar a obra de um artista como Heitor dentro da ideia do "bárbaro" oposto ao "civilizado da elite", e, assim, acaba não vislumbrando

\footnotetext{
${ }^{52}$ Ibidem.

${ }^{53}$ Ibidem.
} 
a dialética de uma produção como a de Heitor ser de fato muito mais complexa do que simplesmente ingênua:

Veja-se a temática de Heitor, ainda que restrita ao folclore urbano, como a sua técnica, seu modo de sentir a forma e de viver a cor, ainda que atenuadas no seu elementarismo de suas primeiras obras por certas preciosidades de virtuosismo, adquiridas na continuação de pintar pelos anos afora.

Tudo neste artista são sugestões vindas do povo onde afinal sempre estiveram as raízes inspiradoras das grandes e autênticas artes universais. ${ }^{54}$

A razão da autenticidade de um artista como Heitor é muito mais apropriada se observarmos sua obra como sendo de um artista da diáspora, que se apropria de códigos culturais (no caso da pintura de cavalete) de maneira não binária - pureza x impureza como quer acreditar Cavalcanti. O artista urbano que Prazeres é indica caminhos diferentes:

\begin{abstract}
Em termos antropológicos, suas culturas (da diáspora) são irremediavelmente "impuras". Essa impureza, tão frequentemente construída como carga e perda, é em si mesma uma condição necessária a sua modernidade. Como observou certa vez o romancista Salman Rushdie, "o hibridismo, a impureza, a mistura, a transformação que vem de novas e inusitadas combinações dos seres humanos, culturas, idéias, políticas, filmes, canções" é "como a novidade entra no mundo". Não se quer sugerir aqui que, numa formação sincrética, os elementos diferentes estabeleçam uma relação de igualdade uns com os outros. Estes são sempre inscritos diferentemente pelas relações de dependência e subordinação sustentada pelo próprio colonialismo. ${ }^{55}$
\end{abstract}

Em relação ao sincretismo, no sentido de resistência e permanência cultural das populações africanas que viveram no regime de escravidão das colônias, já temos a evolução do pensamento deste processo no Brasil através das palavras de Mestre Didi:

[...] assim sendo, todos os Babá, İyálòrìsà, Táta, Doné, Nengua e todos os iniciados e seguidores da religião afro-brasileira podem e devem procurar acabar com o que chamamos sincretismo. Os negros de hoje,

\footnotetext{
${ }^{54}$ Ibidem.

${ }^{55}$ Hall, Stuart. op. cit. p. 34.
} 
para manterem viva a religião de seus antepassados, não é mais preciso dizer que Santo Antonio é Ògún, São Jorge, Òsôsi e Senhor do Bom Fim, Òsàlá, desde quando sabemos que nada disso é real. ${ }^{56}$

Prazeres lida de forma natural com a realidade de sua cidade e com seu próprio trânsito entre a Cidade Nova, as favelas e a zona sul carioca, sem negar sua formação, o terreiro e a convivência com as Tias baianas.

Para a leitura da obra de Prazeres, seja na música, na dança, na pintura ou em outras manifestações, o depoimento do próprio artista no documentário de Antonio Carlos Fontoura, ${ }^{57}$ citando elementos de seu cotidiano presentes em sua obra, comprova a relação de Heitor com elementos mantidos pela população descendente de africanos:

[...] estas figuras que eu faço tem coisas que eu já vi; que ainda existem. Estes bailes, estas macumbas, este samba.

Estas coisas que existem, tanto existem que eu sou um dos que existe, não preciso ver mais, não preciso de modelo, tenho tudo aquilo do passado e de agora dentro de minha memória [...].

Ato surpreendente seria Cavalcanti descartar a visão estrangeira incorporada à formação e ousar outro olhar para a pintura do sambista, aprofundando estudos a partir da África e de seus desdobramentos culturais em terras brasileiras.

\subsection{Clarival do Prado Valladares}

O historiador Clarival do Prado Valladares tem importante influência no incentivo e na interpretação da obra de nosso ilustre Ogã.

Nascido em 1918, na cidade de Salvador, Clarival cursou em Recife o ensino médio e parte de sua graduação em Medicina. Na década de 30, travou contato com

\footnotetext{
${ }^{56}$ Santos, Deoscóderes M. dos. História de um terreiro Nagô. São Paulo: Max Limonad, 1988. In: Sodré, Jaime. A influência da religião afro-brasileira na obra escultórica de Mestre Didi, p.189.

${ }^{57}$ Transcrição de documentário de Antonio Carlos da Fontoura, 1965.
} 
Gilberto Freyre, sendo influenciado por suas idéias e voltando-se para os estudos sociais e a análise das manifestações artísticas. Terminou seus estudos na Bahia, em 1938, mudando-se para o Rio de Janeiro em 1941.

Em 1952, cursou pós-graduação em Patologia na Universidade de Harvard, e Biologia no MIT, ambos em Boston. Ao regressar ao Brasil, em 1956, tornou-se docente em Anatomia Patológica na UFBA, sendo indicado pela Escola de Belas Artes da mesma universidade para o ensino de História da Arte em 1962.

Em 1963, voltou ao Rio de Janeiro e lá viveu até sua morte, em 1983.

Valladares escreveu diversos livros, entre eles Arte e Sociedade nos Cemitérios Brasileiros - 2 volumes; Nordeste Histórico e Monumental - 4 volumes; Aspectos da Arte Religiosa no Brasil - Bahia, Pernambuco e Paraíba; Rio Barroco; Rio Neoclássico; Artesanato Brasileiro; Riscadores de Milagres; Presciliano Silva; Alberto Valença; Lula Cardoso Ayres; Albert Eckout e The Impact of African Culture on Brazil. $^{58}$

Destacamos a preocupação do autor em relação à temática afro-brasileira e africana em terras brasileiras, escrevendo artigos como "O negro brasileiro nas artes plásticas" e “A iconologia Africana no Brasil”, ambos publicados em 1969. Utilizaremos esses textos em nossa análise sobre os conceitos do autor acerca da produção de Heitor dos Prazeres.

Clarival foi crítico de arte e redator-chefe da revista Cadernos Brasileiros (órgão nacional do Congresso para a Liberdade da Cultura), tendo Carlos Cavalcanti e Gilberto Freyre entre seus colaboradores. Conduziu a delegação brasileira no Festival de Artes Negras em Dakar, realizado em 1966 com o lema "Significado da Arte Negra na Vida do Povo e para Povo", e pertenceu ao júri internacional do evento.

\footnotetext{
${ }^{58}$ Biografia cedida pelo Hospital Geral Prado Valladares, Bahia.
} 
Heitor esteve presente nesse evento - que analisaremos com maior profundidade em outro capítulo - divulgando sua música e sua pintura ${ }^{59}$. Clarival foi grande amigo de Prazeres, frequentando seu atelier na década de 60, acompanhando sua produção e apoiando o artista em seu último ano de vida, quando esteve muito tempo hospitalizado devido ao câncer no pâncreas que o levou à morte.

Ao contrário de Carlos Cavalcanti, Valladares, considera Heitor dos Prazeres primitivo e reconhece uma "auto-suficiência cultural absoluta" $" 60$ na expressividade do artista, lembrando que o convívio com outros pintores e os comentários dos críticos não exerceram influência em sua trajetória, tanto em relação aos erros quanto aos acertos de sua produção. Valladares também menciona a influência de Heitor sobre outros “ingênuos e primitivos," já vislumbrando a construção de uma legião de artistas que mercadologicamente viriam copiar seu estilo, percorrendo o "mesmo território folclórico".

Demonstrando preocupação em relação à "presença do negro brasileiro" nas artes plásticas, ele analisa criticamente, como já vimos, o rótulo de primitivo vinculado ao fato de o artista "ser homem de cor, preto, mulato ou índio, procedente da pobreza afim de que a obra seja autêntica pela origem", como garantia de oportunidades àqueles indivíduos, que de outra forma não teriam visibilidade.

Teorizando sobre a questão, Clarival defende que o período colonial teria evidentemente demonstrado uma presença maciça do labor de mãos africanas, sendo que, posteriormente, com o advento da abolição, teria ocorrido a decadência e o afastamento desses artífices.

\footnotetext{
${ }^{59}$ Lírio, Alba. Heitor dos Prazeres: sua arte seu tempo. ND Comunicação, Rio de Janeiro, 2003.

${ }^{60}$ Valladares, Clarival do Prado. Catálogo de exposição de Heitor dos Prazeres, galeria ART, São Paulo, 1967.
} 
Cessada a produção artística coletiva destinada às igrejas e comandadas pelas irmandades, os negros e mestiços sofreram redução dessa via de valorização social do indivíduo. No correr do século passado (XIX), especialmente nas cidades maiores, o artista se definiu naquele capaz de educação dispendiosa, necessariamente no estrangeiro, e de acordo com o gosto dominante da sociedade consumidora.

A consequiência imediata deste procedimento foi a rebaixa do negro para uma margem de afirmação menor. $O$ negro decresce na integração às elites, à proporção em que se acentuam a alienação e sofisticação da sociedade dominante. Os dois últimos processos levam o brasileiro, particularmente o mestiço a assumir a imitação servil, a aplaudir o gosto importado e a aprovar obra e autor pela procedência, pelo endereço que lhe parece civilização, progresso, valor. São poucos os artistas negros ou mulatos de origem popular entre os profissionais consagrados da última metade da centúria passada, notadamente no Rio de Janeiro, a metrópole de poderosa atração para as afirmações vocacionais. ${ }^{61}$

Prado Valladares procura justificar historicamente os fatores que teriam levado

à exclusão desses artistas do panorama das artes visuais brasileiras:

A sociedade brasileira sofreu nesses oitenta anos de libertação da escravatura profundas alterações em seu complexo étnico, com desvantagem para o negro. $\mathrm{O}$ elemento europeu e asiático da imigração continuada até 1950 , a economia organizada dos novos grupos coloniais, a industrialização comandada, a capacidade empresarial e a excelente habilidade de ocupação e de fixação, conferiram ao alienígena desses oito decênios imediata superioridade econômica.

Muito pouco se fez, e ficaram improfícuas, como iniciativas educacionais, as tentativas de organizações que se instalaram sob o propósito de preparar os libertos, os filhos de escravos nascidos sob a Lei do Ventre Livre, para as profissões requeridas pela realidade econômica da época. ${ }^{62}$

Devemos atentar para a questão da imigração, que, incentivada pelo governo

brasileiro, cambiou a mão de obra do descendente de escravos pela do imigrante, alegando que esta troca se devia ao despreparo dos recém libertos. Isso, porém, é injustificável, uma vez que todos os afazeres até então eram designados aos escravos. O

\footnotetext{
${ }^{61}$ Valladares, Clarival do Prado, 1968.

${ }^{62}$ Ibidem.
} 
incentivo ao embranquecimento do Brasil foi decisivo para a marginalização da mão de obra afro-descendente:

A Independência e a República, que em quase toda a América deram lugar a um profundo esforço nacional por elevar o nível cultural da população, capacitando-a para o exercício da cidadania, não ensejaram um esforço equivalente no Brasil.

[...] A máquina só funcionava substancialmente para mais consolidar o poder e a riqueza dos ricos. Com o resultado social dessa política era um atraso vexatório com respeito aos Estados Unidos, por exemplo, se desenvolve nas classes dominantes uma atitude de franco descontentamento para com o próprio povo, cuja condição mestiça ou negra explicaria o atraso nacional.

Em conseqüência, aos motivos econômicos se somam incentivos ideológicos para a realização de enormes investimentos públicos a fim de atrair ao país colonizadores brancos, na qualidade de reprodutores destinados a "melhorar a raça". E não se queriam lusitanos porque também seus avós portugueses se rebelava a alienação oligárquica, convencida de sua própria inferioridade racial e que explicava seus êxitos pessoais como exceções. ${ }^{63}$

Como exemplo importante e digno de estudo Clarival indica Heitor dos

Prazeres, pela originalidade relacionada ao contexto social de sua obra, dotada de "potencialidade narrativa". De acordo com ele, o artista teria sido um caso excepcional de sucesso e autonomia na criação, rompendo com as barreiras de acesso apresentadas pelo autor.

Clarival analisa a obra de Heitor descrevendo o processo de criação de suas pinturas na década de 60, quando Heitor já alcançara sucesso comercial e trabalhava intensamente para atender as encomendas, repetindo figuras e temas.

[...] Como artista ele criava, inventava cenas, figuras e composição. Uma vez aprovado, tanto por seu espírito poético como pela reação do público, passava a repeti-lo conforme os pedidos da freguesia.

A maior parte de sua obra corresponde, pois, a réplicas de cenas que ele criou e depois admitiu como protótipos. Eram temas fixados, variando em dimensão, número de figurantes, de objetos referidos e de cores básicas.[...]

[...] Quando se tratava de um quadro de sucesso, para o qual teria de atender pedidos de vários compradores, fazia-o em esquema, com

\footnotetext{
${ }^{63}$ Ribeiro, Darcy. O povo brasileiro: a formação e o sentido do Brasil. São Paulo: Companhia das Letras, 1995, p. 400-401.
} 
recortes de cartolina, obedecendo às áreas de cor e o contorno de figuras, como se faz no fabrico de vitrais. De manhã, ordenava o trabalho da oficina, dando tarefas a cada assistente. [...]

$\mathrm{O}$ trabalho desenvolvia-se por fases. Havia momentos em que a composição parecia abstrata, antes de receber os "recortes" das figuras dos objetos. Aos assistentes competia pintar decalcando os modelos de cartolina ainda sem cabeças, mãos e pés. Heitor dos Prazeres permitia aos auxiliares atuar até as cores da roupa, mas a ele competia, rigorosamente, fazer o desenho e o colorido da face e o movimento dos gestos.

Acompanhando-o mais de perto, pude verificar que enquanto produzia uma pintura comercializada, em telas, para as galerias e colecionadores, através do trabalho de assistentes em sistema de oficina, a ninguém permitia participar da pintura que ele mesmo fazia nos tecidos dos trajes das cabrochas de seu conjunto musical. Também era assim que costumava fazer em pratos de madeira, em cartão de natal e às vezes em simples motivos florísticos, para encomendas de pessoas de seu nível social. Nesses exemplos, ele mesmo fazia todo o trabalho sem ajuda de outrem. A produção comercial de seu estúdio, no seu modo de entender, estava certa e nada tinha de se estranhar. ${ }^{64}$

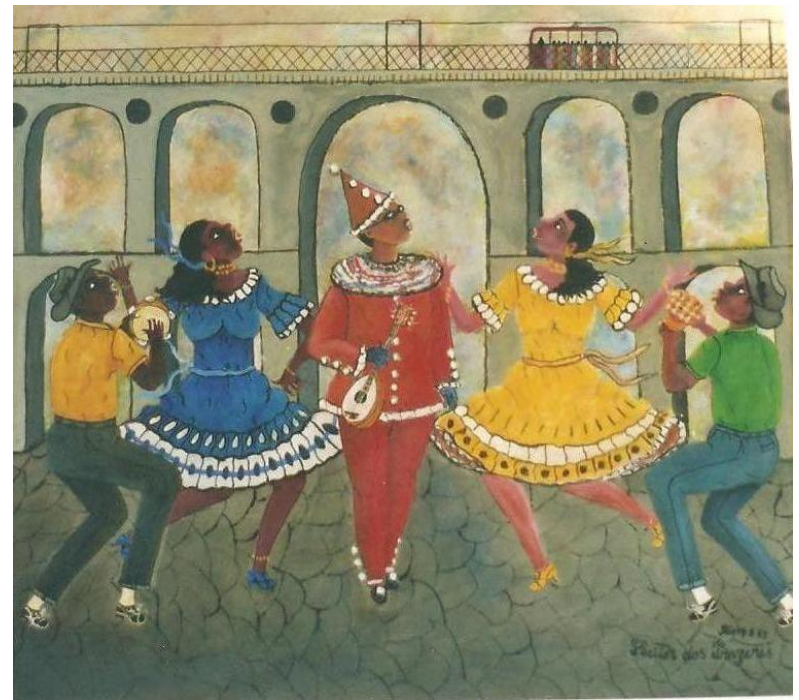

Sem Título, 1964, óleo sobre tela. Coleção Museu Afro Brasil.

${ }^{64}$ Lírio, Alba. op. cit., p. 150-151. 


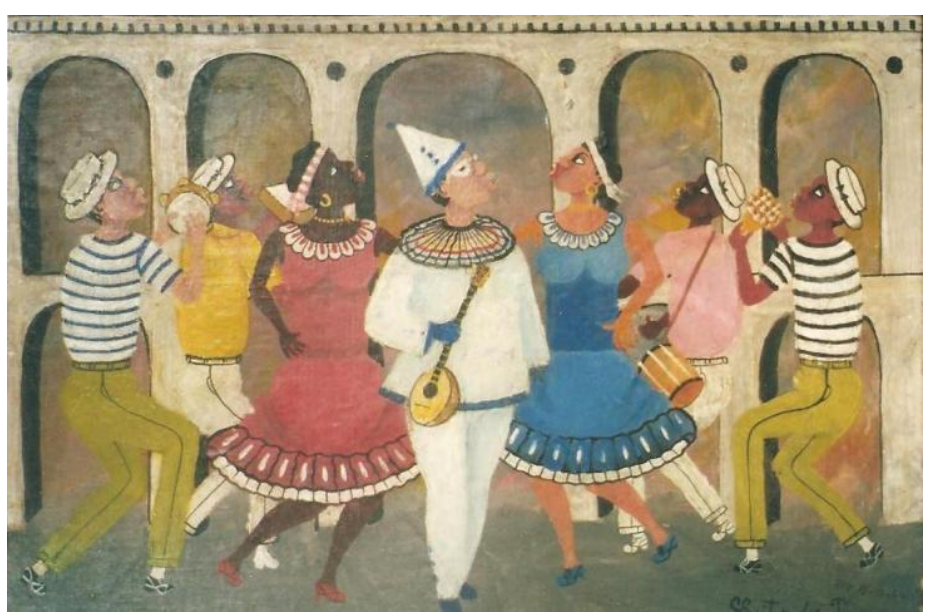

Sem Título, 1963, óleo sobre eucatex., Coleção Museu Afro Brasil.

A repetição temática caracteriza o artista dentro do contexto da arte moderna. Acreditamos que, além das questões comerciais, a temática recorrente é um indício da importância de um determinado tema para a identidade da obra, assim como as bandeirinhas na pintura de Volpi, por exemplo. Além disso, não podemos esquecer que na década de trinta, o pintor compôs com Noel Rosa a famosa canção Pierrô Apaixonado, e naturalmente a figura do pierrô, assim como as cenas de carnaval foram representadas constantemente pelo artista, justamente devido ao vínculo com seu ofício de músico e com o carnaval propriamente dito.

As imagens criadas por Heitor dos Prazeres, na opinião de Clarival, eram “portadoras de uma mensagem: o anseio da integração racial numa sociedade ideal”. Ele retratava histórias e paisagens das quais fazia parte, distintamente de tantos artistas modernistas que iam ao mangue ou ao morro retratar algo que não lhes pertencia, interpretando e apropriando-se de um elemento que não era deles, pintando temas de fácil sucesso comercial, como as mulatas de Di Cavalcanti.

A contradição se faz presente quando pintores como Di não são confundidos com primitivos - muito menos com ingênuos ou selvagens -, por habitarem uma esfera social diferente, apesar de visitarem a temática "morro, mangue, terreiro". 
E por falar no pintor Di Cavalcanti, definimo-lo como um dos casos mais esquisitos do grã-finismo paulista. O casal Di Cavalcanti, Di propriamente dito e a esplêndida pintora Noêmia, são queridíssimos nas rodas elegantes de São Paulo.

[...] Di recebe telefonemas e convites para as melhores festas e as mais disputadas reuniões. Todo o grã-fino e grã-fina anseiam ser pintados por Noêmia. [...] É coqueluche, como eles dizem [...] E Di, no fundo, é quem mais se diverte com aquilo tudo e de vez em quando consegue vender uma tela sua qualquer grã-fino. ${ }^{65}$

Essa esfera social distinta define a maneira com que Di pintava uma mulata e a forma como a mulher negra era representada numa pintura de Prazeres. Enquanto no primeiro o estereótipo da mulher sensual brasileira era o assunto central, em Heitor essa mulher é mais inteira, indo além do objeto de exploração, como apresentado em Casa Grande e Senzala, impondo sua condição feminina de forma muito mais ampla.

\subsection{Rubem Braga}

E chegamos a Rubem Braga (1913-1990). Tido por tantos como um dos maiores cronistas do Brasil depois de Machado de Assis, o escritor capixaba contribui com sua interpretação a respeito do artista e sua obra. Em seu livro Três Primitivos, datado de 1953, ele realizou um estudo comparativo entre pintores considerados populares no Brasil.

Braga analisa nesse estudo os precursores do que seria a arte ingênua em nosso país, sendo eles Cardosinho (1861-1947), Heitor dos Prazeres (1898-1966) e José Antônio da Silva (1909-1996). O autor anuncia que não pretende analisar tecnicamente a pintura:

\footnotetext{
${ }^{65}$ Silveira, Joel. Grã-finos em São Paulo, VVAA, Reportagens que abalaram o Brasil. $1{ }^{\text {a }}$ Edição, Rio de Janeiro: Bloch Eds. S.A., 1973, p. 88. In: Arte Privilégio e distinção. P. 105.
} 
Deixemos de lado qualquer exame técnico da obra desses três homens, o que estaria de resto, fora de nosso campo. Apenas procuramos dar aos seus quadros, aqui reproduzidos, o fundo de uma vida e ambiente que são, afinal, zonas legítimas da realidade e do sentimento brasileiros. ${ }^{66}$

Devemos considerar que a publicação desse material localiza-se num período em que a pintura de Heitor já era conhecida, tendo participado da primeira Bienal de Arte de São Paulo, em 1951, com a obra Moenda premiada em terceiro lugar (Prêmio Toddy de Aquisição).

Boa parte da análise de Rubem Braga destaca passagens conhecidas da biografia do artista, comentando o começo de tudo:

Foi em 1937 que começou a fazer uns quadrinhos "para enfeitar a parede". O jornalista e desenhista Carlos Cavalcanti o estimulou, disse que ele tinha jeito; suas primeiras aquarelas ficaram com Vicente Leite. Começou a fazer uns óleos muito escuros. ${ }^{67}$

Quando Rubem descreve o assunto das telas, ele parece discordar da opinião

de Clarival a respeito dos anseios do pintor em relação à sociedade, pois acredita que:

Sua pintura é uma flor natural de seu samba e de sua vida, de seu meio e de suas mulatas de quem ele desenha com amor todos os dentinhos brancos. Se às vezes exprime algum drama social, como "Os refugiados" em que aparece a gente pobre carregando seus trastes, expulsa do barraco de uma favela qualquer, ou uma reivindicação racial, como naquela sala de jantar em que uma família preta é servida por uma copeira branca, quase sempre reflete momentos amenos da vida da gente do samba, não bem a de hoje, mas os do tempo já antigo, em que para além de São Cristovão o Rio de Janeiro era muito rural.

Quando questionado a respeito da série de pinturas que representavam pessoas

fugindo entre as matas, Heitor explicou: “é gente do morro. Uma ideia que me veio.

Não estão derrubando as favelas?" 68

\footnotetext{
${ }^{66}$ Braga, Rubem. op. cit., p. 3-4.

${ }^{67}$ Ibidem.

${ }^{68}$ Lírio, Alba. op. cit.
} 


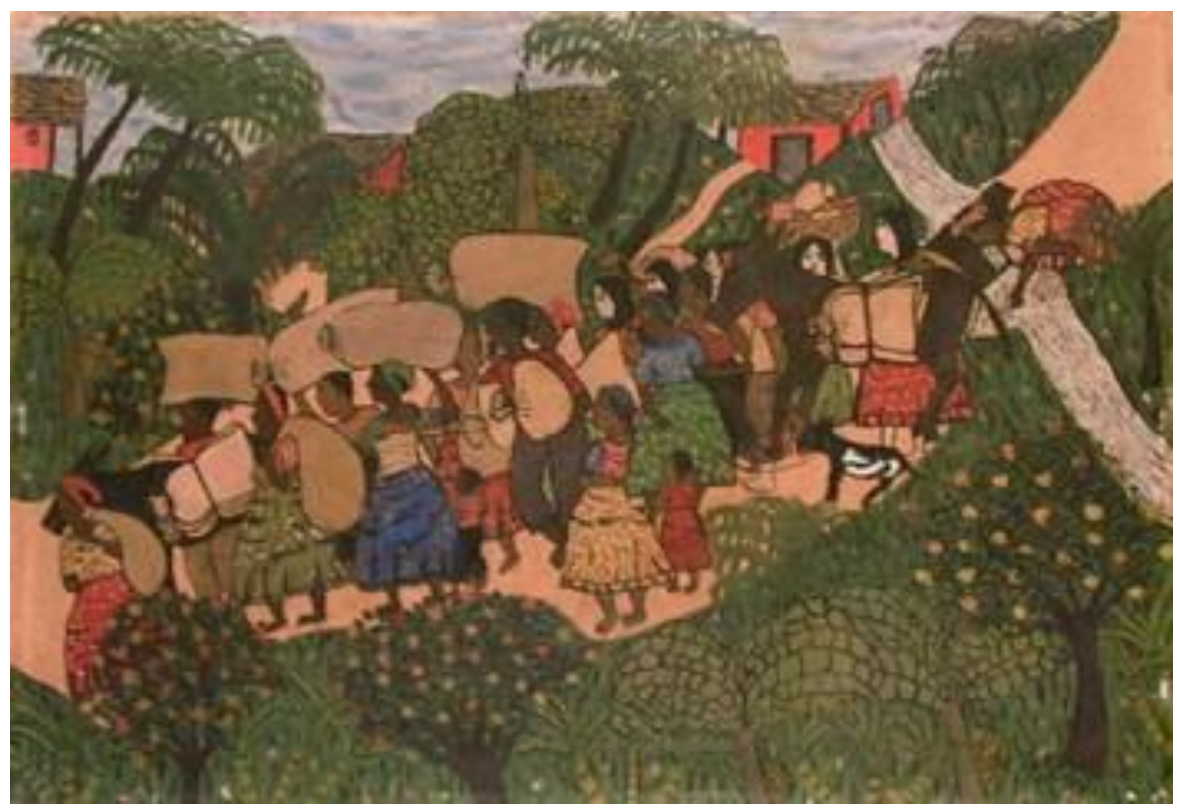

Descendo o Morro, óleo sobre cartão, 36,5 x 54,5 cm. ${ }^{69}$

Braga recorda o fato de Heitor ter começado a pintar a partir dos 40 anos, lembrando que as telas do sambista muitas vezes tratam de "recordações da vida", como a imagem da Praça Onze que Carlos Drummond de Andrade tinha em sua casa, e que na realidade não era mais como aparecia na pintura do artista.

Relembrando as imagens da "roça" pintadas pelo artista, Rubem Braga afirma que elas se tratavam de

[...] uma ressonância da roça em que ele nunca viveu [...] assim é mais fiel à sua cidade, cujo sentimento rural os pobres que vêm vindo renovam sem cessar, e mesmo um homem nascido na Cidade Nova ainda é no Brasil, como somos todos, uns vagos exilados do país "essencialmente agrícola". ${ }^{70}$

Segundo o escritor, "sua imensa riqueza interna veio ganhar na pintura uma expressão irmã do samba, e seria fácil reconhecer o ritmista na composição dos quadros". Rubem prossegue afirmando que Heitor "não faz pintura do Partido Alto para deleite dos ricos", e encerra o texto afirmando que sua pintura é "uma expressão

\footnotetext{
${ }^{69}$ Fonte: Bolsa de Arte do Rio de Janeiro, obra em leilão de abril de 2003.

${ }^{70}$ Rubem Braga, op.cit., p. 14.
} 
legítima do Rio de Janeiro atrapalhado e saboroso a que a miséria nunca pode tirar o gosto intensíssimo da vida". ${ }^{71}$

Além da análise que fez em livro sobre o pintor sambista Prazeres, Braga escreveu em sua coluna para o Jornal do Brasil, em 30 de julho de 1964, sobre a demissão do sambista da Rádio Nacional por questões políticas:

A Última Hora e a Tribuna da Imprensa concordaram afinal em alguma coisa: em estranhar e reprovar as numerosas demissões na Rádio Nacional. Hélio Fernandes abunda em adjetivos: 'absurdas, despropositadas, sem sentido, desumanas, desnecessárias e impopulares'.

O Marechal Castelo Branco pode estar certo que praticou uma grave tolice ao assinar essas demissões [...].

Heitor dos Prazeres, pintor e sambista, é uma das figuras mais queridas da vida carioca e no lugar de demiti-lo depois de 22 anos de serviço como ritmista da Nacional, o governo, se tivesse imaginação e senso de justiça, devia era inscrever seu nome na Ordem Nacional do Mérito [...]. ${ }^{72}$

\subsection{Carlos Drummond de Andrade}

Entre tantos amigos, Carlos Drummond de Andrade se destaca. Ele foi apresentado ao pintor por Carlos Cavalcanti na década de 30, quando Heitor morava na Praça Tiradentes. Sua intenção era ter um poema seu musicado pelo sambista; ao recebê-lo, Prazeres acabou transformando os versos em pintura.

No período em que Drummond foi chefe do Gabinete do Ministro Capanema, ele empregou Heitor no Departamento de Patrimônio Histórico e Artístico do Ministério da Educação e Cultura - Laboratório de Restauração de Artes - como auxiliar de restauração.

\footnotetext{
${ }^{71}$ Ibidem.

${ }^{72}$ Lírio, Alba. op. cit.
} 
Em 1967, o poeta escreveu no catálogo de uma exposição póstuma do amigo pintor:

\begin{abstract}
Não sei como os sábios explicam o 'caso' Heitor; a mim, que sou leigo me parece um resultado feliz de aculturação: toda a vivacidade e delicadeza de elementos originais do negro se preservaram nele, em contato com formas culturais diversas; e sem choque, mas sem a renúncia ao que ele tinha de melhor em sua ancestralidade. Heitor se integrou na cultura urbana e cosmopolita do Rio, dando-nos ao mesmo tempo um exemplo de pureza e autenticidade. ${ }^{73}$
\end{abstract}

Segundo Luis da Câmara Cascudo, "a aculturação é o resultado da influência de padrões estrangeiros na cultura orgânica de um povo"; Cascudo afirmou que "os povos de índice cultural 'inferior' têm uma personalidade defensiva muito mais eficiente que os povos medianos, de cultura agenciada, em detrimento dos padrões nacionais lógicos" 74 .

Carlos Drummond de Andrade, na tentativa de compreender a produção artística de Mano Lino, definiu suas referências como "elementos originais do negro" relacionados a culturas diversas, sem que Heitor perdesse sua "ancestralidade" sinônimo de pureza.

Stuart Hall, citando Mary Louise Pratt, ${ }^{75}$ defende que o processo de "resultado híbrido" das culturas das colônias na América torna difícil a tarefa de desagregar elementos "autênticos de origem", afirmando ser a "lógica colonial" de um "tipo transcultural":

Através da transculturação "grupos subordinados ou marginais selecionam e inventam a partir dos materiais a eles transmitidos pela cultura metropolitana dominante". É um processo da "zona de contato", um termo que invoca a "co-presença espacial e temporal dos sujeitos anteriormente isolados por disjunturas geográficas e históricas [...] cujas trajetórias agora se cruzam”. Essa perspectiva é dialógica, já

\footnotetext{
${ }^{73}$ Andrade, Carlos Drummond. Catálogo de exposição da Galeria Art, São Paulo, 1967.

${ }^{74}$ Cascudo, Luís da Câmara. Civilização e Cultura. São Paulo: Global Editora, 2004.

75 Pratt, Mary Louise. "Imperial Eyes: Travel Writing and Transculturation". In: Hall, Stuart. Da diáspora: identidades e mediações culturais. Org. Liv Sovik. Belo Horizonte: UFMG, 2003, p. 31.
} 
que não é tão interessada em como o colonizado produz o colonizador e vice-versa.

É fato também que, a essa transculturação que marcou a identidade de Prazeres como artista urbano moderno, soma-se a noção de "comunidade imaginada" 76. a Praça Onze como a Pequena África, frequentada e vivida por aqueles sambistas, com suas tias baianas a construir a identidade da população.

\footnotetext{
76 Anderson, Benedict. Imaginated Communities. $2^{\text {a }}$ Edição. London: Verso, 1991. In: Hall, Stuart. $D a$ diáspora: identidades e mediações culturais. Org. Liv Sovik. Belo Horizonte: UFMG, 2003, p. 26.
} 


\section{Pintura}

\subsection{Arte afro-brasileira}

Uma ciência não escapa à ideologia quando oblitera as condições de seu aparecimento ou de sua produção. Um saber é engajadamente ideológico quando recalca não apenas as circunstâncias de sua produção, mas também todo e qualquer outro saber possível em torno de seu campo. ${ }^{77}$

A arte europeia sofreu grande modificação a partir da Renascença, tendo seu significado social profundamente alterado.

Digno de nota seria não considerarmos a produção de pinturas, esculturas sacras e encomendas feitas pela corte, pela Igreja e por pessoas da alta sociedade, que eram, naquele período, o veículo para o desenvolvimento da obra de artistas como Michelangelo e Da Vinci - para citarmos apenas as referências mais populares, afinal este não é um estudo a respeito da Renascença Italiana.

Mário Pedrosa considera o Renascimento a obstrução do processo de permanência transmitido através de mitos e ritos, que teriam a função de preservação de “modos de observação e reflexões exatamente adaptados a descobertas autorizadas pela natureza". ${ }^{78} \mathrm{O}$ autor desenvolveu suas formulações a partir do conceito de Lévi-Strauss sobre os mitos e os ritos, apostando na importância do chamado primordial da natureza, em que a relação com a observação e a reflexão não teria mera função fabuladora. ${ }^{79}$

Segundo ele, a função de mitos e ritos seria, na verdade, uma estratégia de manutenção de "modos de observação e reflexões exatamente adaptados a descobertas

\footnotetext{
77 Sodré, Muniz. Prefácio de Contos Crioulos da Bahia, Mestre Didi. In: Sodré, Jaime. A influência da religião afro-brasileira na obra escultórica de Mestre Didi. p. 181.

${ }^{78}$ Pedrosa, Mario. Mundo, Homem, Arte em Crise. $2^{\text {a }}$ Edição. São Paulo: Perspectiva, 1986, p. 227.

79 Strauss, Claude Lévi-. O pensamento Selvagem. $8^{\text {a }}$ Edição. São Paulo: Papirus. In: Pedrosa, Mario. Mundo, Homem, Arte em Crise. $2^{\mathrm{a}}$ Edição. São Paulo: Perspectiva, 1986, p. 227-228.
} 
autorizadas pela natureza" ${ }^{80}$ Entretanto, o próprio autor admite que a arte sacra, ainda na Alta Renascença, tinha a função religiosa de instruir o povo sobre episódios da vida de Cristo ou das Santas Escrituras, que são essencialmente relacionadas a mitos e ritos daquela sociedade.

De certo modo, tanto na Europa quanto na África a arte fluiu em processos que envolviam questões sociais, comerciais e estéticas, adequadas às suas necessidades. $\mathrm{O}$ problema do choque entre os conceitos estéticos de cada civilização é concomitante ao processo de colonização em que diferentes culturas entram em contato; a despeito da diversidade de culturas que os europeus encontraram, os desdobramentos desses encontros resultaram em dominação e crescente subordinação.

Temos alguns exemplos das civilizações africanas encontradas pelos viajantes europeus no período de sua expansão colonialista:

[...] A Etiópia, no século IV assiste ao apogeu do Império de Aksum, vinculado ao Reino de Sabá, que professava o cristianismo antes da conquista dos árabes. No Sudão, por influência muçulmana, florescem os Reinos de Gana, Shongai, Kanem, e Malinké, entre os séculos XI e XIV. Universidades já funcionavam em localidades como Timbuctú ou Gao, antes da Europa. No século XVI, portugueses conheceram outros impérios isentos da influência muçulmana, como Manicongo, no Congo, cujos reis se converteram ao cristianismo, tendo inclusive um príncipe consagrado como o primeiro bispo negro.

Os europeus também tiveram contatos com os reinos feudais Yorubá, Dahomey, Benin, entre outros, e com as zonas chamadas Costa do Marfim, de Escravos e do Ouro, que faz referência ao comércio ali praticado. a observação comum a estes reinos é a existência de soberanos divinos, com sua corte integrada por artistas, como escultores, entalhadores, músicos, poetas, fundidores de bronze, sacerdotes, e uma população urbana muito especializada em seus ofícios, como comerciantes e artesãos. ${ }^{81}$

\footnotetext{
${ }^{80}$ Ibidem.

81 Sodré, Jaime. op. cit., p. 85.
} 
Esse processo de dominação repercutiu na formação do Brasil, país colonizado com a base de seu desenvolvimento estruturada principalmente a partir da mão de obra africana na condição de escravidão.

A partir de um depoimento de John Luckok - mercador inglês que viajou pelo Brasil entre os anos de 1808 e 1818 , e que em 1820 publicou um livro que trata da cidade do Rio de Janeiro e da região sul do país -, podemos analisar a dimensão das mãos africanas na construção do Brasil, então colônia de Portugal:

Toda a casa em que se prezava era provida de escravos aos quais se haviam ensinado algumas ou mais artes comuns da vida e que não somente trabalhavam nessas especialidades (carpinteiros, pedreiros, ferreiros) para a família a que pertenciam como eram também alugados pelos senhores e pessoas não tão bem providas quanto aqueles. Não conseguiam ganhar muito.

[...] Antes das dez horas da manhã, quando o sol começava a subir alto e as sombras das casas se encurtavam, os homens brancos se faziam raros pelas ruas e viam-se então os escravos mandraceando à vontade, ou sentados à soleira das portas,fiando, fazendo meias ou tecendo uma espécie de erva com que fabricavam cestos e chapéus. Outros prosseguiam nos seus trabalhos de entregadores, saíam a recados ou levavam à venda, sobre pequenos tabuleiros frutas, doces, armarinhos, algodõezinhos estampados e uns poucos outros gêneros. Todos eles eram pretos, tanto homens como mulheres, e um estrangeiro que acontecesse de atravessar a cidade pelo meio-dia quase que poderia supor-se transplantado para o coração da África. ${ }^{82}$

Certamente, na arte desenvolvida em terras brasileiras o uso dessa mão de obra se tornou imprescindível, pois, durante séculos, foi ela quem ergueu igrejas, esculpiu o barroco brasileiro, construiu palácios, pintou tetos e os decorou. Mesmo que os mestres daqueles afazeres muitas vezes fossem europeus, a grande dimensão dessas obras implicava o trabalho cativo.

Aprendendo por força da necessidade do seu trabalho, um ofício, ou exercendo uma atividade considerada não mecânica, conforme a época, o negro e sua conseqüência, o mulato ou o pardo, soube impor sua equidade de criação e sua compreensão, nos parâmetros dos seus legados culturais africanos, do mundo luso-brasileiro [...] nada se pode

\footnotetext{
${ }^{82}$ Luckock, John. Notas sobre o Rio de Janeiro e partes meridionais do Brasil. In: Neves, Maria de Fátima Rodrigues das. Documentos sobre a escravidão no Brasil. São Paulo: Contexto, 1996.
} 
estudar, em arte no Brasil, sem estabelecer a relação com os homens de cor. ${ }^{83}$

Esse fato contribui para compreendermos a representação de santos e anjos com características africanas na cor da pele, nas feições e nos cabelos muitas vezes encontrados em pinturas e entalhes das igrejas coloniais.

Na conexão da afro brasilidade à arte cristã, o dado que primeiro salta aos olhos é a representação de santos e anjos com traços negróides, o amulatamento das figuras representadas em pinturas, retábulos e imagens católicas. ${ }^{84}$

Roberto Conduru problematiza a questão do início das artes no Brasil e questiona sobre qual África poderia teria permanecido e forjado a arte nacional. O autor chega a cogitar atavismos culturais ou "forças plásticas e simbólicas que ressurgem não racionalmente", descartando a transmissão de informações de mestre para aprendiz, tão difundida na África e que aqui se manteve no exercício de ofícios.

[...] negros de ganho, foram empregados como carregadores, estivadores, ferreiros, pedreiros, carpinteiros, fabricantes de carruagens e de móveis, tipógrafos, pintores, ourives, litógrafos, escultores em madeira e pedra $[\ldots] .{ }^{85}$

Jaime Sodré, analisando mais profundamente a questão, afirma que a cultura negra sobreviveu ao que poderia ser chamado de seu extermínio porque soube se guardar no recesso de comunidades religiosas, nas irmandades, e especialmente nos terreiros. De acordo com ele, "a resistência e adaptação revelam a permanência do essencial, que hoje cultuamos, no sentido amplo". ${ }^{86}$

\footnotetext{
${ }^{83}$ Araújo, Emanoel (org). A mão afro brasileira: significado da contribuição artística e histórica. São Paulo: Tenenge, 1988. In: Sodré, Jaime, op.cit.

${ }^{84}$ Conduru, Roberto. Arte afro brasileira. Belo Horizonte: C/Arte, 2007.

${ }^{85}$ Pierson, Ronald. Branco e pretos na Bahia. São Paulo: Editora Nacional, 1971, p. 20. In: Sodré, Jaime. A influência da religião afro-brasileira na obra escultórica de Mestre Didi.

${ }^{86}$ Sodré, Jaime, op. cit., p. 182.
} 
Não importa o quão deformada, cooptadas e inautênticas sejam as formas como os negros e as tradições e comunidades negras pareçam ou sejam representadas na cultura popular, nós continuamos a ver nessas figuras e repertórios, aos quais a cultura popular recorre, as experiências que estão por trás delas.Em sua expressividade, musicalidade, sua oralidade e na sua rica,profunda e variada atenção à fala;em suas inflexões vernaculares e locais; em sua rica produção de contranarrativas; e,sobretudo, em seu uso metafórico do vocabulário musical, a cultura popular negra tem permitido trazer à tona, até nas modalidades mistas e contraditórias da cultura popular mainstream elementos de um discurso que é diferente - outras formas de vida, outras tradições de representação. ${ }^{87}$

Podemos afirmar que essa cultura permaneceu principalmente na forma de resistência, pois os processos de repressão e coação eram inúmeros, e a manutenção da transmissão de conhecimentos é garantida em nossas terras através da adesão e preservação de manifestações culturais ao longo dos séculos;

A persistência de formas culturais africanas foi favorecida pela concentração de negros na cidade do Salvador, em especial dos "negros de ganho", semi-independentes, em torno dos quais se reunia um contingente considerável de pretos livres, pouco assimilado. ${ }^{88}$

Como vimos no primeiro capítulo, o cenário do Rio de Janeiro é semelhante ao de Salvador, uma vez que muitos membros de comunidades baianas deslocaram-se para a capital federal. As casas das Tias baianas seguiam um curso similar às da Bahia, em que

também nessa época, ouviam-se com freqüência, em cerimônia do candomblé, músicas de origem africana, isso por volta de 1900, e "numerosas imagens usadas na adoração afro brasileira eram importadas da África e outras eram feitas na Bahia por escultores de cor". ${ }^{89}$

A manutenção de tradições é a garantia da arte afro-brasileira como compreendida nos dias de hoje, pois, ao longo dos anos, ela sofreu adaptações, adquiriu

\footnotetext{
${ }^{87}$ Hall, Stuart. op. cit., p. 323-324.

${ }^{88}$ Sodré, Jaime, op. cit., p. 114.

${ }^{89}$ Pierson, Ronald. Brancos e Pretos na Bahia. São Paulo: Editora Nacional, 1971, p. 120. In: Sodré, Jaime, op. cit., p. 114.
} 
novas maneiras de veiculação e aderiu a novas tecnologias, comprovando sua importância e garantindo sua sobrevivência, haja vista que a cultura não pode se tornar estática, a não ser que esteja morta.

Primeiro, peço que observem como, dentro do repertório negro, o estilo - que os críticos culturais da corrente dominante muitas vezes acreditam ser uma simples casca, uma embalagem, o revestimento de açúcar na pílula - se tornou em si a matéria do acontecimento. Segundo, percebam como, deslocado de um mundo logocêntrico onde o domínio direto das modalidades culturais significou o domínio da escrita e, daí, a crítica da escrita (crítica logocêntrica) e a desconstrução da escrita -, o povo da diáspora negra tem, em oposição a tudo isso, encontrado a forma profunda a estrutura profunda de sua vida cultural na música. Terceiro, pensem como essas culturas têm usado o corpo como se ele fosse, e muitas vezes foi, o único capital cultural que tínhamos. Temos trabalhado em nós mesmos como em telas de representação.

Existem aqui questões profundas de transmissão e herança cultural, de relações complexas entre as origens africanas e as dispersões irreversíveis da diáspora; questões que não vou aprofundar aqui. Mas acredito que esses repertórios da cultura popular negra - uma vez que fomos excluídos da corrente cultural dominante - eram frequentemente os únicos espaços performáticos que nos restavam e que foram sobredeterminados de duas formas: parcialmente por suas heranças, e também determinados criticamente pelas condições diaspóricas nas quais as conexões foram forjadas. A apropriação, cooptação e rearticulação seletivas de ideologias, culturas e instituições européias junto a um patrimônio africano [...] conduziram a inovações lingüísticas na estilização retórica do corpo, as formas de ocupar um espaço social alheio, a expressões potencializadas, a estilos de cabelo, a posturas, gingados e maneiras de falar, bem como a meios de constituir e sustentar o companheirismo e a comunidade. ${ }^{90}$

Desta forma, a arte afro-brasileira nos leva a problematizar de que forma se

constituiu e os motivos de ser assim nomeada:

A questão fundamental que se coloca não é descobrir nas artes plásticas afro-brasileiras os universais da arte em geral, mas sim de defini-la, ou melhor, descrevê-la em relação à arte brasileira de um modo generalizado. Em outras palavras, se a arte afro-brasileira é apenas um capítulo da arte brasileira, por que então este qualificativo "afro" a ela atribuído?Descobrir a africanidade presente ou escondida nessa arte constitui uma das condições primordiais de sua definição.

Mas que africanidade é essa, quando sabemos que os criadores dessa arte são descendentes de africanos escravizados que foram transplantados no Novo Mundo?Transplantação essa que operou um

\footnotetext{
${ }^{90}$ Hall, Stuart, op. cit., p. 324-325.
} 
corte e, consequentemente, uma ruptura, que, hipoteticamente, teria provocado uma despersonalização, ou seja, uma perda de identidade, ficam colocados o problema e as condições de continuidade dos elementos de africanidade nessa arte, por um lado, e a questão das novas formas recriadas no Novo Mundo e de como essas novas formas poderiam ainda ser impregnadas de africanidade, por outro. ${ }^{91}$

Exemplificando os modos de permanência de elementos africanos culturais e artísticos em terras brasileiras - elementos que, segundo Munanga, "para que possam ser retidos na memória de um indivíduo cortado de suas raízes é preciso que pertençam ao núcleo de sua existência, pois é este último que sobrevive à ruptura" -, percebemos os desdobramentos complexos dessas manifestações na nova organização social imposta:

[...] podemos concluir que a continuidade e a recriação de todos os elementos da arte africana não foram integrais, porque a totalidade de suas estruturas social, política, econômica e religiosa não foi transportada para o Novo Mundo. No entanto, a continuidade de algumas formas de sua arte só foi recriada parcialmente, em função de suas novas condições de vida. Outras não foram recriadas pois, tendo em vista que se tratava de uma arte utilitária e funcional, elas não encontraram um quadro funcional suficiente para se manterem apesar de sua presença na memória coletiva.Seria o caso entre outros, das artes da corte [...]. Com efeito, as cortes reais africanas das regiões de onde foram trazidos homens e mulheres que foram escravizados no Brasil (reinos do Congo, Cuba, Luba, Lunda, Cokwe etc., na África Central, e os reinos Yorubá, Fon, Ashanti etc., na África Ocidental), assim como todas as instituições a elas ligadas, foram motivos de grandes obras de arte. ${ }^{92}$

O autor afirma que a religiosidade é "um campo cultural muito resistente, no qual se pôde nitidamente observar o fenômeno de continuidade dos elementos culturais africanos no Brasil", embora a "conversão dos negros africanos" figurasse "entre os motivos evocados no século XVI para legitimar e justificar a escravidão”.

\footnotetext{
${ }_{91}^{91}$ Munanga, Kabengele. op. cit., p. 98-111.

${ }^{92}$ Ibidem.
} 
Naturalmente, a produção de objetos litúrgicos foi necessária para as práticas religiosas; para Munanga, "é assim que surge a primeira manifestação das artes plásticas afro-brasileiras. Uma arte sem dúvida religiosa, funcional e utilitária.”

Como vimos no segundo capítulo, é a partir da década de 30 do século XX que verificamos novos rumos para as manifestações artísticas de características africanas, com modificações adaptadas à realidade brasileira.

A expansão desta expressão para fora dos terreiros desencadeou a produção de uma arte diversificada em relação ao que seria a temática relacionada á afro brasilidade; de acordo com Munanga, há os que "se utilizam do tema incidentalmente" (Tarsila do Amaral, Lasar Segall, Alberto da Veiga, Guignard, Portinari, Djanira, José Pancetti, Santa Rosa, entre outros), “da mesma maneira que o fazem com a indígena, a europeia, ou outras que possam polarizar sua criatividade pessoal". Para ele, que cita estudos de Marianno Carneiro da Cunha para elaborar essas classificações, não seria possível considerar esses artistas como sendo afro-brasileiros, pois isso "equivaleria a chamar o Picasso das Demoiselles d'Avignon de afro-francês ou afro-espanhol”.

Os artistas que de maneira consciente e sistemática lançaram mão da temática afro-brasileira seriam Carybé, Mario Cravo Jr., Hansen Bahia e Di Cavalcanti. Para Kabengele Munanga, entretanto, seria arriscado considerar Di como um afro-brasileiro em sua arte, pois o oposto - a busca de um ideal de beleza feminina branca - poderia gerar a classificação de artistas brancos ou negros como euro-brasileiros.

O terceiro grupo pertence ao de artistas que usaram a temática espontânea e inconscientemente; ele cita "Guma, um branco gaúcho, e Louco, negro de Cachoeira, na Bahia”. Para problematizar mais ainda a questão, Munanga questiona como classificaríamos as obras da maioria dos artistas afro-brasileiros negros e mestiços, já que os da primeira e da segunda categoria seriam brancos. 
Alguns elementos, segundo ele, poderiam ser indicadores de vantagens da interpretação dos âmbitos de africano e brasileiro juntos. Esses elementos seriam:

[...] a forma ou o estilo; as cores e seu simbolismo; a temática; as fontes de inspiração, todos harmoniosamente articulados através do domínio de uma técnica capaz de dar corpo e existência a uma obra de arte autêntica. Outros como a monumentalidade, a repetição, a desproporção entre partes do corpo e a conceituação das idéias vêm se somar para aprofundar a diferença entre a arte africana no singular, a arte ocidental e outras. ${ }^{93}$

Para Munanga, o estudo da arte afro-brasileira está apenas começando, e carece de alguns "postulados básicos" para que possa "merecer e conservar seu atributo e qualificativo de "afro"”. Por isso, faz-se necessário o estudo específico desses artistas, que ainda devem ser profundamente analisados. Kabengele enumera alguns: "Agnaldo Manuel dos Santos, Rubem Valentim, Ronaldo Rego, Hélio de Oliveira, Mestre Didi, Abdias do Nascimento, Emanoel Araújo, Sidney Lisardo etc.”. Incluímos, entre esses artistas, o trabalho de Heitor dos Prazeres.

\subsection{Brasil brasileiro}

As primeiras décadas do século XX no Rio de Janeiro não foram favoráveis a uma maior aceitação da cultura da população dos cortiços e subúrbios que se encontrava na Praça Onze e nas festas da Penha:

[...] o que poderíamos chamar de ascensão social do samba, um gênero tão execrado pelas classes dominantes das primeiras décadas do século que a polícia prendia quem o cantasse, dançasse ou tocasse. $\mathrm{E}$ ai daquele que andasse pelas ruas carregando um violão. Sendo negro aí mesmo é que a situação piorava ${ }^{94}$.

\footnotetext{
${ }^{93}$ Ibidem.

${ }^{94}$ Cabral, Sérgio. Prefácio de Mistério do Samba, de Hermano Vianna. Rio de Janeiro: Jorge Zahar Ed., 2004.
} 
Entretanto, na capital do Brasil, uma transição ocorreu em relação à aceitação daquela manifestação cultural, que foi gradualmente incorporada até tornar-se símbolo da expressão nacional. Como vimos anteriormente, isso se deu através da atuação dos sambistas, dentro da lógica dialética entre governo, intelectuais, boêmios (muitas vezes boêmios e intelectuais), através da "luta cultural" enunciada por Stuart Hall.

Capital do Brasil desde 1763, o Rio de Janeiro era o destino de levas de brasileiros livres e escravos, além de africanos vindos diretamente de seus países de origem, transformando a cidade numa espécie de síntese da cultura popular do país. [...]

A Europa e a África influenciavam decisivamente a vida do carioca de modo geral, e, em particular, o seu carnaval. ${ }^{95}$

Em depoimento citado no livro O Mistério do Samba, de Hermano Vianna,

Donga relembra a casa em que morava com Pixinguinha e Heitor dos Prazeres na Rua do Riachuelo, centro do Rio de Janeiro, no início dos anos 10:

Embora sendo um antigo pardieiro [...] nos sentíamos bem instalados e achamos boa a nova residência. No local, éramos visitados por gente como Catulo da Paixão Cearense, Olegário Mariano, Bastos Tigre, Hermes Fontes, Medeiros de Albuquerque, Edmundo Bittencourt, Emilio de Menezes, Gutemberg Cruz e o grande Dr. Afonso Arinos de Mello Franco, presidente na época da Academia Brasileira de Letras. Ele nos apreciava tanto que sempre nos convidava para as audições em sua residência, na praia de Botafogo, e na sua fazenda, no Tombadouro [...]. ${ }^{96}$

A quantidade de artistas que pintaram, entalharam, esculpiram, dançaram tocaram e cantaram, criando um conjunto de manifestações ao longo da história do país muito antes de o primeiro samba ser tocado, deram corpo a um acervo artístico-cultural que resultou nessa construção de identidade do século passado.

\footnotetext{
${ }_{95}^{95}$ Cabral, Sergio. As Escolas de Samba do Rio de Janeiro. Rio de Janeiro: Lumiar, 1996, p. 19-20.

${ }^{96}$ Vianna, Hermano, op. cit.
} 
Inseridos neste panorama, passemos a investigar o ponto de partida da obra de

Heitor dos Prazeres: o samba e seus protagonistas.

\title{
4.3 Pintura de Heitor
}

Foi no ambiente do terreiro de Tia Ciata, na convivência na Praça Onze e nas festas da Penha, que Heitor dos Prazeres,Ogã Alabê-Nilu filho de Xangô, ainda menino, tocou suas primeiras composições. Coerente com seu universo e com suas referências culturais, ele utilizou aquele mesmo repertório anos mais tarde, em suas pinturas figurativas que representam imagens das rodas de samba, dos terreiros, da arquitetura das favelas, do mangue, dos bares dos boêmios, do carnaval - enfim, do cotidiano dos bairros suburbanos onde viveu, e de um Brasil rural que nele ecoava, embora não tivesse propriamente vivido nele.

\begin{abstract}
A minha pintura para mim é importante. É uma fuga das minhas dores, das minhas mágoas, do meu sofrimento, das minhas paixões. Eu me sinto num outro mundo, um mundo sofredor, um mundo gozador, um mundo de felicidade. Um mundo feliz. É, a pintura me dá toda essa alegria, me proporciona tudo isso que é riqueza para mim. $\mathrm{Na}$ pintura eu sonho, eu sonho música, eu sonho momentos amorosos, eu sonho alegria, enfim, tudo eu sonho, tudo me dá riqueza. Não consigo fazer nada que não existe porque eu não me sinto bem. Estas figuras que eu faço são de coisas que eu já vi, que ainda existem, estes bailes, estas macumbas, estes sambas, estas coisas que existem. Tanto existem que eu sou um dos que existem. Não preciso ver mais, não preciso modelo. Eu tenho tudo aquilo do passado e de agora, dentro da minha memória. ${ }^{97}$
\end{abstract}

Como seu trabalho de coreógrafo, compositor e instrumentista continuou a se desenvolver durante os anos de sua produção pictórica, não devemos analisar sua pintura isoladamente, sem considerar o contexto de suas outras formas de expressão.

\footnotetext{
${ }^{97}$ Transcrição de documentário de Antonio Carlos da Fontoura, 1965.
} 
O envolvimento com a dança, o corpo, a música, o carnaval carioca e as amizades acabou por ecoar em sua produção, como se fosse um registro desses eventos; como se ele tivesse a necessidade de contar, através da pintura, aquilo que via e vivia. Em sua maneira de pintar - com figuras de um rigor decorativo, simétricas em sua composição, organizadas seriada e repetidamente como em um ritmo -, as cores vibrantes e "carnavalescas", que possuíam delicadas variações tonais, tingiam as imagens de mulheres e homens a dançar ou a celebrar alguma coisa. Dessa maneira, Heitor dos Prazeres procurava ilustrar seu próprio olhar sobre as heranças culturais e as paisagens urbanas em que vivia.

Podemos considerar as pinturas de Heitor como um valioso registro de um dos ambientes de maior efervescência cultural de nosso país, berço das primeiras escolas de samba do Brasil.

Sua produção ficou rotulada como naïf devido ao autodidatismo e ao repertório visual de suas imagens, vinculadas a cenários "populares". Este rótulo foi aceito - ou, pelo menos, não contestado - por Prazeres provavelmente por razões comerciais, visto que as encomendas não cessavam, obrigando-o a articular uma equipe para produzir suas pinturas sob sua orientação, como descreve Clarival em sua análise a respeito da produção do artista. Temos aqui uma reflexão a respeito desse processo pelas palavras do próprio artista:

[...] Mas é triste algumas coisas que eu faço que o destino não me agrada. Coisas que eu faço que tenho amizade, que eu pretendia guardar pra mim. Então vem um, gosta, leva, vem outro, faço outra coisa, vem outro, gosta, leva. Então já me sinto já acorrentado, obrigado a fazer comércio de formas que são desagradáveis.

É um sofrimento pro artista, porque já me sinto comercializado. Eu sinto que já estou fracassando, por quê? Fracassando por que eu sou obrigado a fazer coisas que não estão na minha vontade por causa do comércio. Eu faço uma coisa que inspiro, a pessoa vem e pede outro igual, depois vem outro e pede outro igual, depois vem outro e pede outro igual, de forma que é uma tristeza. O artista que é obrigado a 
comercializar-se, a atender situações de mercado, vive acorrentado e acaba morrendo não fazendo aquilo que ele quer (sic). ${ }^{98}$

Entretanto, caracterizar sua obra como ingênua acaba por reduzir a análise da produção do artista. O estereótipo de pureza, ignorância e infantilidade impede o simples ato de perceber sutilezas, nuances da obra sob outras perspectivas, pois a produção de Heitor dos Prazeres, artista urbano, não diferia muito do que era produzido pelos modernistas. Em razão de enriquecer assim a discussão acerca de sua obra, é preciso desconsiderar a possibilidade de que um artista possa estar num estado de pureza intocável - semelhante ao de crianças - e não sofrer influência daquilo que está ao seu redor; principalmente se considerarmos uma cidade efervescente como o Rio de Janeiro, a atuação deste artista no rádio, em turnês musicais dentro e fora do Brasil, e suas participações em Bienais, desempenhando uma função pública no Ministério da Educação e Cultura da outrora capital do país.

Pretendemos analisar a pintura de Heitor dos Prazeres a partir de suas obras em acervos de museus cariocas e paulistas, observando a temática de cada uma das quatro décadas compreendidas entre o período dos anos 30 até os anos 60. Além disso, pretendemos analisar a ligação de sua produção com a herança afro-brasileira, destacando eventos importantes para sua carreira, como as Bienais de São Paulo, a Feira de Arte de Dakar e outras exposições.

O contato com imagens era uma realidade urbana da cultura de massa. A imprensa carioca estava em franco desenvolvimento, produzindo jornais, almanaques, revistas e cartazes em profusão nas primeiras décadas do século XX. As ilustrações eram feitas por importantes desenhistas e caricaturistas, como J. Carlos, Crispim do Amaral, K. Lixto, entre outros, e Heitor não estava isolado deste contexto urbano.

\footnotetext{
${ }^{98}$ Ibidem.
} 


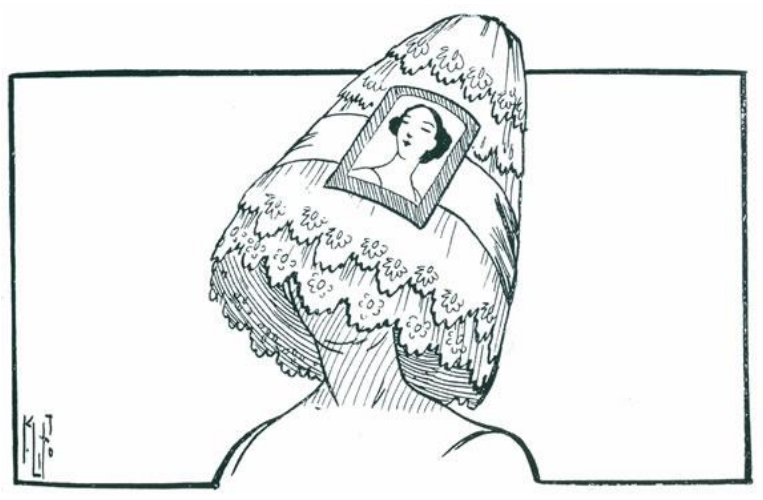

Charge de K.Lixto para a revista Fon Fon, em 1912.

No início do século e nas cinco décadas seguintes, temos publicações como as revistas $\underline{\text { Careta }}$ (1908-1960), $\underline{\text { O Cruzeiro }}$ (1928-1975) e $\underline{O \text { Malho}}$, que foi uma revista

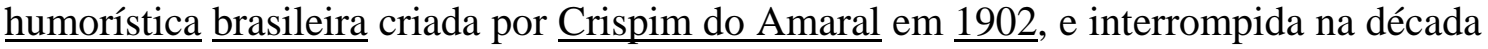
de 30. Tanto O Malho quanto a revista Para Todos - entre 1922 e 1930 - foram dirigidas pelo grande designer e caricaturista J. Carlos.

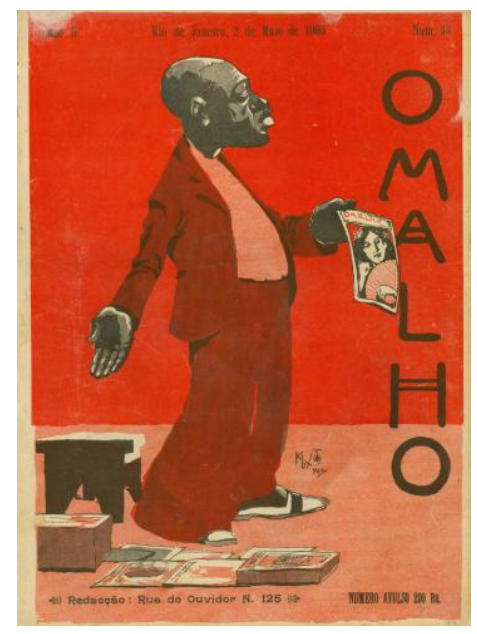

Ilustração de K. Lixto para a capa da revista $O$ Malho, maio de $1903 .{ }^{99}$

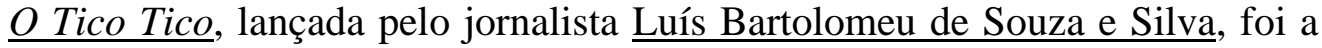
primeira revista a publicar histórias em quadrinhos no Brasil. Sua primeira edição saiu

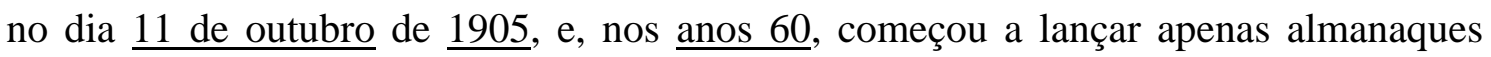

\footnotetext{
${ }^{99}$ Fonte: Fundação Casa de Rui Barbosa.
} 
ocasionais, sendo finalmente fechada. Houve também a Revista da Semana, semanário brasileiro editado de $\underline{1900}$ a $\underline{1962}$, e a Fon Fon, publicada entre 1907 até $1958 .{ }^{100}$

Na década de 30, mais precisamente em 1931, a revista Para Todos publicou uma matéria de duas páginas sobre as festas da Penha. Heitor dos Prazeres figurou como personagem central dessa crônica sobre o evento, que aqui citamos na íntegra:

Há um samba em cada barraca, no arraial da Penha.As melodias se misturam, e de longe parece que não são muitas, mas uma só meio desarticulada, cantada por 100 violões, animada por mil gargantas.De perto, porém tudo se vae desaggregando, subdividindo-se, e então aqui se nota bem nitido, o "Arrependido", ali "Deixa essa mulher chorar" e lá longe, na subida do morro, "o Rancho fundo" chorando numa voz mais dolente.

E antigamente a Penha não era assim.Dizem os que vieram do passado que a Penha era, sobretudo uma apotheose à virgem boa que vive no alto, espalhando bênçãos sobre a cidade grande, fazendo milagres, socorrendo os afflictos, dando-lhes, de graça, esperanças immensas....

Veio depois o samba, que fascina tanto, e acampou ao pé do morro, rendendo também aqui de baixo, a sua homenagem á padroeira que mora lá em cima, em montanha de granito...

Não digam ao sambista que elle está commettendo um peccado, agindo assim.

Naquella orgia de música bohemia - seria muito infeliz quem dissesse que a virgem não faz milagres...O sambista que canta pela sua virgem e pelo seu amor, saltaria como um louco, para defender a verdade que elle cultua com a maior de todas as devoções...E o arraial seria, todo elle,um campo de guerra santa pela gloria de todas as coisas christãs... Olha-se em torno daquela paisagem quasi interminável de feira colorida:e ha milhares de cabeças levantadas para o alto, recebendo gostosamente a cerveja loura que cahe tantos copos suspensos ao ar.

É a Penha - exaltação de todos os sentidos romanticos do homem simples.

Canuto é como um Gary Cooper que tivesse nascido em Favella.Vem com o seu grupo cantando os seus sambas:

"Vou a Penha rasgado

Pra pagar uma promessa

Eu não sou malandro

Porque tenho trabalhado

Vou de chinello charlotte

Terno de cimento armado

Só é o que a nota tem dado.."

É a Penha - treino individual de samba para as grandes olympiadas de Momo...

No outro lado impera a fantasia de Heitor dos Prazeres, e as morenas que cantam "Mulher de malandro":

${ }^{100}$ Fonte: Biblioteca Nacional, Rio de Janeiro. 
"Mulher de malandro sabe ser

carinhosa de verdade

Ella vive com tanto prazer e quanto

Mais apanha

Ella tem amizade

Longe de mim tem saudade..."

Casam-se no espaço debaixo da sombra das árvores e das barracas, as orações profanas da vida e do amor.

E encontram-se, no alto,com os canticos que descem da igreja exaltando a morte...

É a Penha provando, com a realidade das coisas, que o dictado dos livros classicos - "in Vino Veritas" - continua sendo o mais perfeito de todos os espelhos do mundo, porque e mais forte que raio-x e porque põe na testa de toda gente um cartaz bem explicativo que afasta todas as duvidas. ${ }^{101}$

Além das publicações da época, de acordo com depoimento do pintor no documentário de Antonio Carlos da Fontoura, a cartilha de sua infância marcou sua memória. Segundo ele, que dizia ter passado por "mais de duzentas e sessenta e uma escolas", as figuras da Cartilha Felisberto Carvalho, fartamente ilustrada, foi um contato marcante.

Na minha infância existia a cartilha de Felisberto Carvalho, a qual tinha umas ilustrações e aquelas ilustrações apenas é que me seduziam e eu não consegui aprender a ler e escrever até hoje. Porque as ilustrações é que me seduziam e o que me interessava era desenhar, eu coloria aquelas ilustrações. ${ }^{102}$

Semelhante a muitas crianças, Heitor desenhava por gosto, mantendo esse hábito mesmo durante sua carreira como músico já consolidada. Não eram raros os momentos em que amigos de boemia, como o jornalista Carlos Cavalcanti, o viam a rabiscar guardanapos ou papéis que tivesse em mãos. Heitor decidiu dedicar-se à pintura com mais afinco na década de 30 do século passado, época em que perdeu sua primeira esposa. Ele optou, inicialmente, por imagens introspectivas, sem pretensões comerciais.

\footnotetext{
${ }^{101}$ Revista Paratodos, sem identificação de autor, edição de 07/11/1931, nº 637, p. 7.

${ }^{102}$ Transcrição de documentário de Antonio Carlos da Fontoura, 1965.
} 
No início, "Heitor pintava com tinta guache, preparada por ele mesmo [...]. Mais tarde passou a utilizar a técnica de pintura a óleo”. ${ }^{103}$ Sua paleta de marrons e azuis deu o tom a cenas como Sonho, guache sobre cartão de 1939, em que o artista aparece dormindo no centro da tela, sonhando com sua falecida esposa representada ao lado esquerdo.

Esta cena em nada remete ao propalado imaginário primitivo ou ingênuo, tão festejado pela crítica e consumido pelo público em décadas posteriores. A pintura em questão traz uma cena onírica bem ao gosto das ilustrações da época, transfigurando o inconsciente do sonhador em retrato flutuante a visitar seus sonhos, compartilhando a agonia (da perda da amada) com o espectador.

Ao lado direito do sonhador, vemos o relógio medindo o tempo, imagens na parede (fotografias, talvez?) e parte do estojo de violão. No centro, sonhando, virado para a imagem projetada por seu inconsciente, ele parece recusar as coisas terrenas à direita da tela, almejando a figura feminina; ela, por sua vez, não olha para ele, e é representada perto da cadeira vazia, sendo que os mesmos tons de azul escuro colorem tanto seu vestido quanto o encosto e o assento da cadeira. O quarto, ambiente privado revelado através da pintura, convida o espectador a invadir sua intimidade.

Percebemos nesse princípio a preocupação do artista com seu universo particular. Essa obra esteve presente nas paredes anteriormente nuas de sua casa na Praça Tiradentes, surpreendendo os frequentadores de sua residência, atentos a todas as manifestações artísticas do criativo sambista.

\footnotetext{
${ }^{103}$ Lírio, Alba; Prazeres $\mathrm{F}^{\circ}$, Heitor dos. Heitor dos Prazeres: sua arte seu tempo. Rio de Janeiro: ND comunicação, 2003.
} 
O desenho da pintura, presente nos contornos das linhas cuidadosamente pinceladas em cor preta que delimitam a geografia de toda a massa de cor vertida pelo guache, aponta a tradição do desenho e da figuração na arte brasileira contemporânea ao artista, aparecendo também nas obras de Di Cavalcanti e Portinari, entre outros.

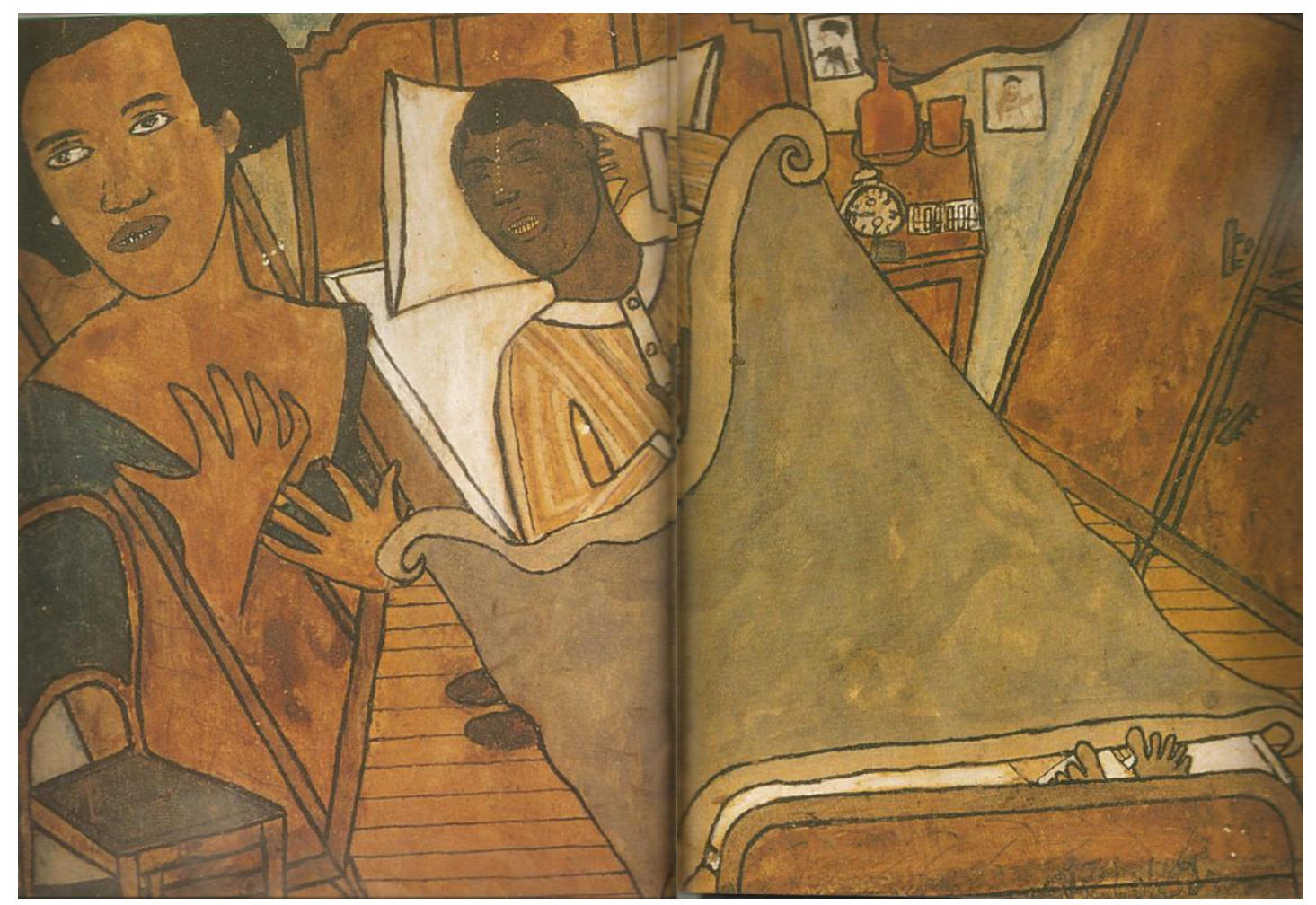

Sonho, 1939, guache sobre cartão, $20 \times 28 \mathrm{~cm}$. Coleção da família.

Nas cores e na temática, essa obra guarda semelhanças com a produção do influente pintor pernambucano Cícero Dias (1907-2003), o ilustrador das páginas de Casa Grande e Senzala (1933), de Gilberto Freyre. Dias também teve, por assim dizer, sua fase surrealista entre a década de 20 e o final dos anos 30, período vivido intensamente no Rio de Janeiro.

Na cidade do Rio, entre 1925 e 1928, frequentou cursos de arquitetura e pintura na Escola Nacional de Belas Artes (Enba), mas não concluiu nenhum deles. Dedicou-se à pintura em 1928, participando do Movimento Antropofágico iniciado por 
Oswald de Andrade (1890-1954). Conviveu com Pagu, Anita Malfatti (1889-1964), Raul Bopp (1898-1984) e Pedro Nava (1903-1984), entre outros.

Em 1929, Cícero Dias participou do Primeiro Congresso Afro-Brasileiro, movimento a favor da arte e da cultura organizado por Gilberto Freyre (1900-1987) em Recife. Nesse período, tornou-se colaborador da Revista de Antropofagia. Em 1937, executou cenário e figurino para o balé O Jurupari, de Villa-Lobos e Sérgio Lifar, no Rio de Janeiro; em 1931, expôs a obra Eu Vi o Mundo... Ele Começava no Recife no Salão Revolucionário da Enba, causando grande escândalo. ${ }^{104}$

Em catálogo de exposição póstuma de Heitor no ano de 2005, 0 curador Antonio Carlos Abdalla atesta o contato de Prazeres com Cícero Dias:

\begin{abstract}
Apesar de ter se iniciado na pintura relativamente tarde, foi reconhecido e inclui, entre seus amigos próximos, gente do porte de Djanira, Marc Berkowitz, Clarival do Prado Valladares, Augusto Rodrigues, Cícero Dias, José Geraldo Vieira, Jayme Mauricio, Rubem Valentim, Carybé, Agnaldo dos Santos, Carlos Scliar, Aldemir Martins, Flavio de Carvalho e tantos outros artistas, jornalistas e escritores que freqüentaram as bienais de São Paulo e o famoso barzinho do Museu de Arte Moderna e Clube dos Artistas da Arte, do Instituto dos Arquitetos do Brasil. ${ }^{105}$
\end{abstract}

Utilizamos como referência as obras Sonho de uma prostituta e Sonho, pintadas por Dias no começo da década de 30. Seus tons azuis e telúricos, além da temática, guardam semelhança com a alegoria criada por Heitor, a delicadeza na estrutura do desenho e a presença da linha também são marcantes na construção da obra de ambos os artistas.

\footnotetext{
${ }^{104}$ Fonte: Itaúcultural, 2009.

${ }^{105}$ Fonte:Catálogo da exposição H.P.:Um pierrô apaixonado na BM\&F;2005
} 


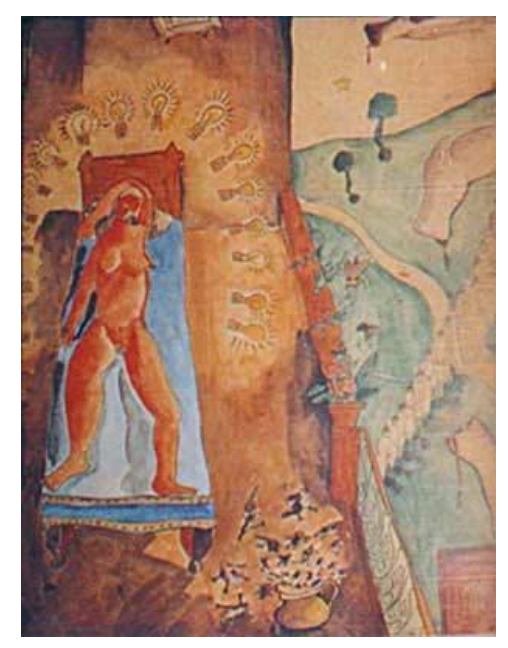

Sonho de uma prostituta, 1930-32, aquarela sobre papel, 55,5 x $50 \mathrm{~cm}$. Coleção Chateaubriand Bandeira de Mello.

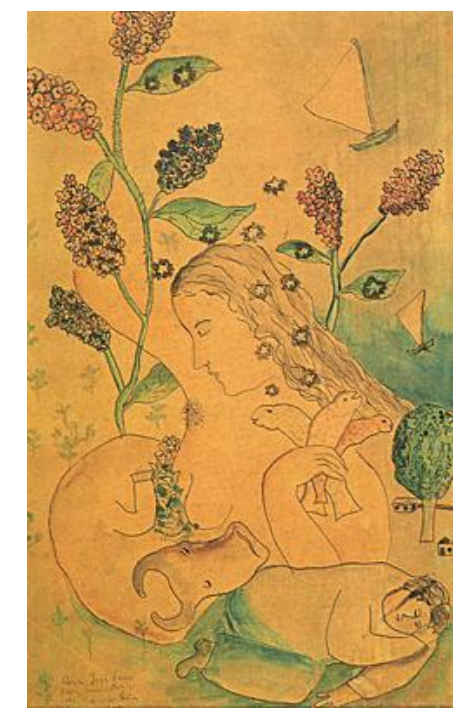

Sonho, 1930, aquarela sobre papel, c.i.e. 50 x $30 \mathrm{~cm}$. Coleção Gilberto Chateaubriand - Museu de Arte Moderna do Rio de Janeiro.

Analisando o desenho de Sonho, consideremos uma imagem da Cartilha Felisberto de Carvalho citada por Heitor ao se lembrar de seu tempo de menino, cuja primordial função era o ensino da leitura e da escrita, acrescido da instrução moral. Essa cartilha foi referência nas escolas desde a última metade do século XIX até a década de 40 do século XX. 


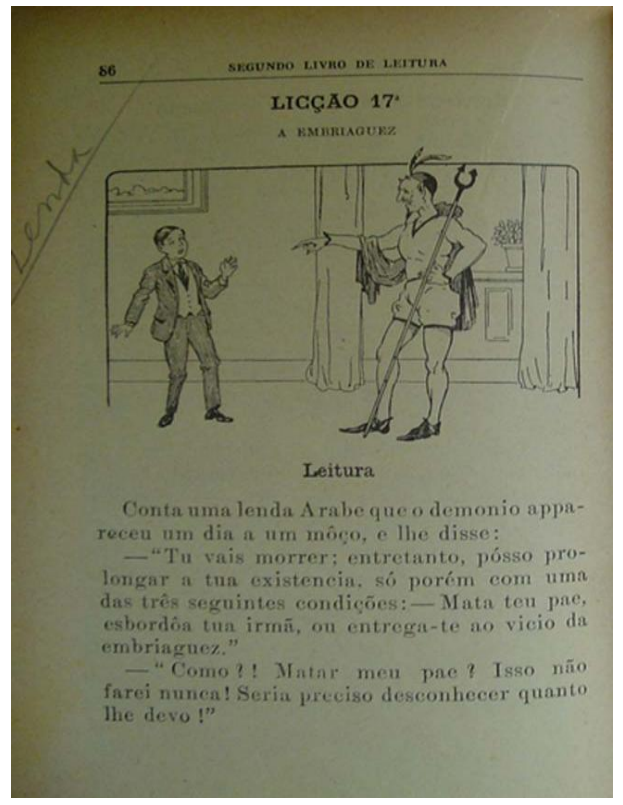

Página do segundo livro de leitura de Felisberto de Carvalho, com texto moral para uso de treino caligráfico ( $\left(90^{\mathrm{a}}\right.$ edição, de 1934, com prefácio datado de junho de 1891, Niterói, $\left.\mathrm{RJ}\right)$.

Nas ilustrações que seduziram o menino, e que foram coloridas por ele, as figuras das lições destacam a linha e o contraste entre preto e branco. Observamos a ênfase no uso da linha de contorno preenchida de cor - ou a massa colorida contornada com intenção de destacar as formas - não só neste guache sobre cartão de 1939, mas na maioria de suas pinturas, o que nos leva a imaginar seu processo de pintar semelhante ao de colorir figuras.

Outra professora de desenho que ele teve foi sua mãe, Celestina Gonçalves Martins, costureira e bordadeira. Com ela, Heitor aprendeu o que mais tarde aplicou na criação de figurinos e bordados para si e para suas pastoras usarem em apresentações públicas, treinando o trabalho de riscar a matriz do bordado - que consiste em copiar ou criar um traçado original em papel fino para decalcar o desenho nos tecidos, base das linhas e cores do bordado. No documentário já citado de Antonio Carlos Fontoura, vemos o artista folheando um caderno repleto desses desenhos feitos por ele em papel de seda; na sequência, o pintor executa o decalque de um desenho original para outro suporte. 
O processo de decalcar, apresentado no documentário e descrito no segundo capítulo, permitia ao artista reproduzir ou reordenar figuras já representadas em pinturas anteriores, facilitando o trabalho de seus assistentes na atividade de comercializar sua obra e atendendo à demanda de sua clientela. Entre os clientes, temos seu amigo Cartola (1908-1980), que conviveu com Heitor desde os tempos da Tia Ciata. Sendo mais novo, Cartola fazia parte da "ala jovem", com Pixinguinha, Paulo Benjamin de Oliveira (Paulo da Portela)e Donga, entre outros. ${ }^{106}$

Durante essa convivência, Cartola solicitou uma encomenda a Heitor:

A amizade de Heitor dos Prazeres e Cartola também seguiria por toda a vida, nos momentos bons e nas horas difíceis de um e de outro. Em 1964, dois anos antes de morrer, Heitor dos Prazeres, já consagrado como pintor, criou o convite de casamento de Cartola e Dona Zica e com o mesmo tema ilustrou o cardápio do restaurante Zicartola, um sobrado na tradicional Rua da Carioca, no Centro do Rio de Janeiro, misto de bar e casa de shows de samba, fundada por Cartola e Dona Zica, com a parceria de Sérgio Cabral, por onde passaram grandes nomes do samba e da bossa nova. ${ }^{107}$
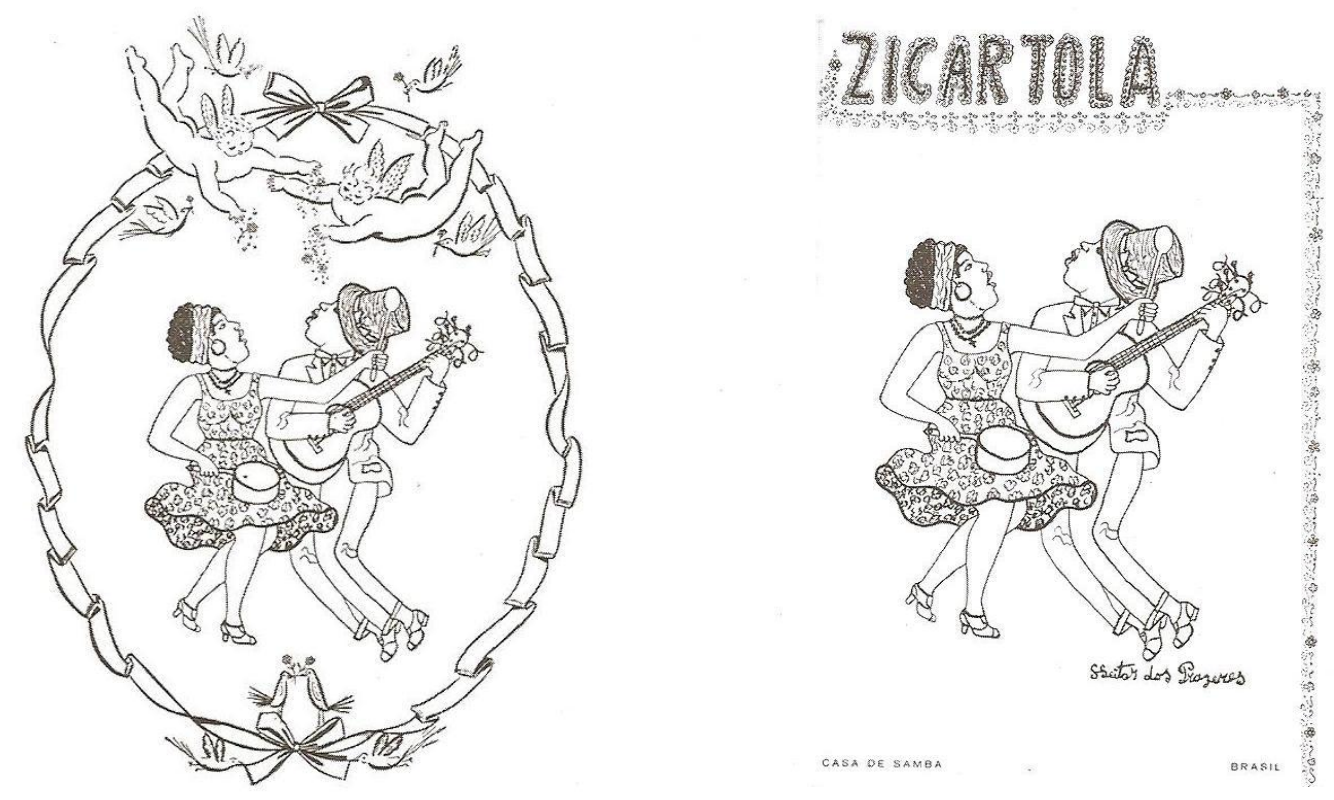

Desenhos para Cartola e Dona Zica, 1964 (divulgação do bar Zicartola e convite de casamento).

\footnotetext{
${ }^{106}$ Lírio, Alba; Prazeres F ${ }^{\circ}$, Heitor dos. op. cit., p. 55.

${ }^{107}$ Ibidem, p. 79-80.
} 
O caráter decorativo dessas duas ilustrações é evidente na minúcia de pequenos detalhes, cuidadosamente arquitetados para ornar a imagem das duas figuras que representam a união entre Dona Zica e o sambista Cartola.

O aspecto das imagens desses desenhos guarda semelhança com anúncios de revistas desenhados nas primeiras décadas de 1900. Também como referência, temos as figuras para bordado, que costumavam ser repletas de ornamentos e pequenos detalhes, assim como as ilustrações citadas.

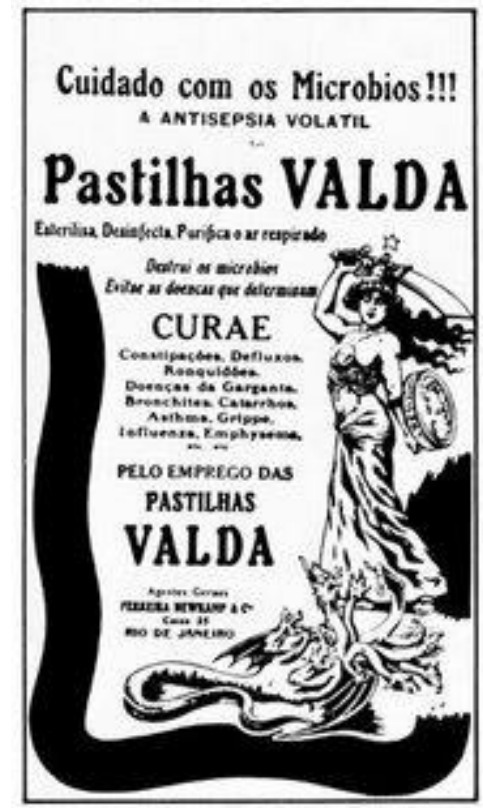

Anúncio das Pastilhas Valda publicado na Revista Careta, número 165, Rio de Janeiro, $1914 .^{108}$

Os esboços do acervo do Museu Nacional de Belas Artes revelam uma linha mais orgânica, em um processo antecedente ao acabamento dado na conclusão dos trabalhos em pintura ou à nanquim.

${ }^{108}$ Fonte: Casa de Rui Barbosa. 


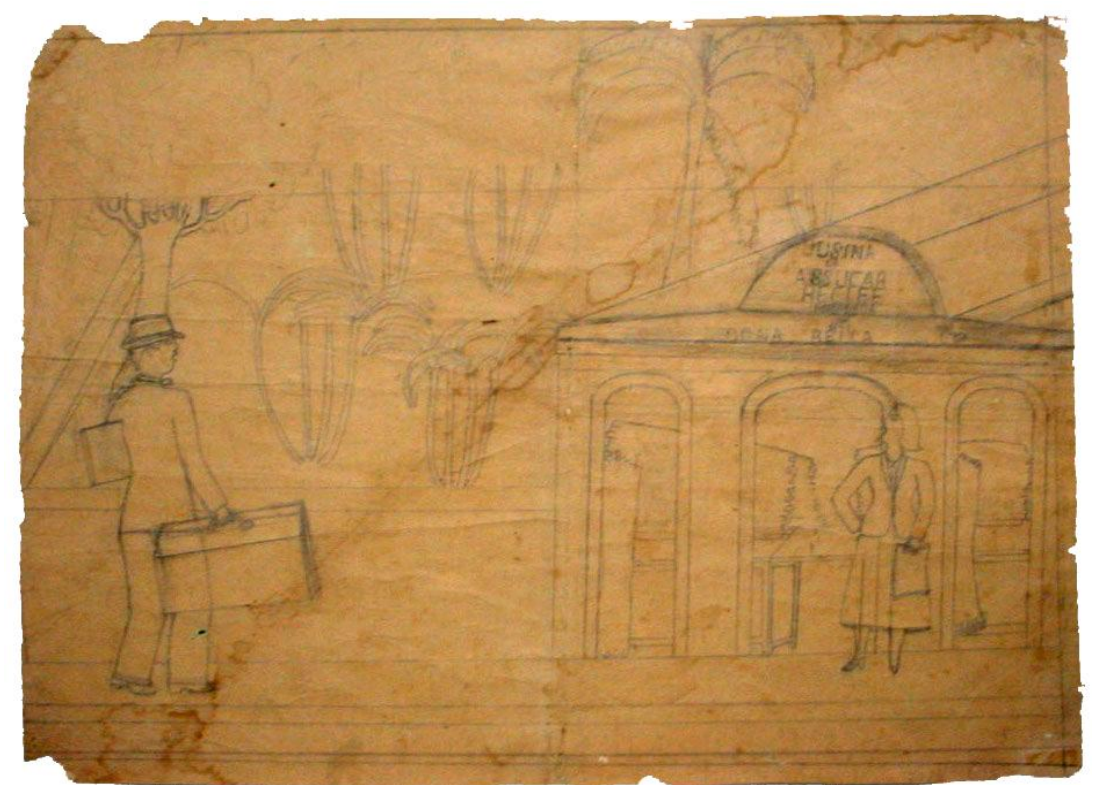

Usina de açúcar, grafite sobre papel colado num suporte de papel vergê, $32,5 \times 43,4 \mathrm{~cm}$. MNBA, RJ, sem data.

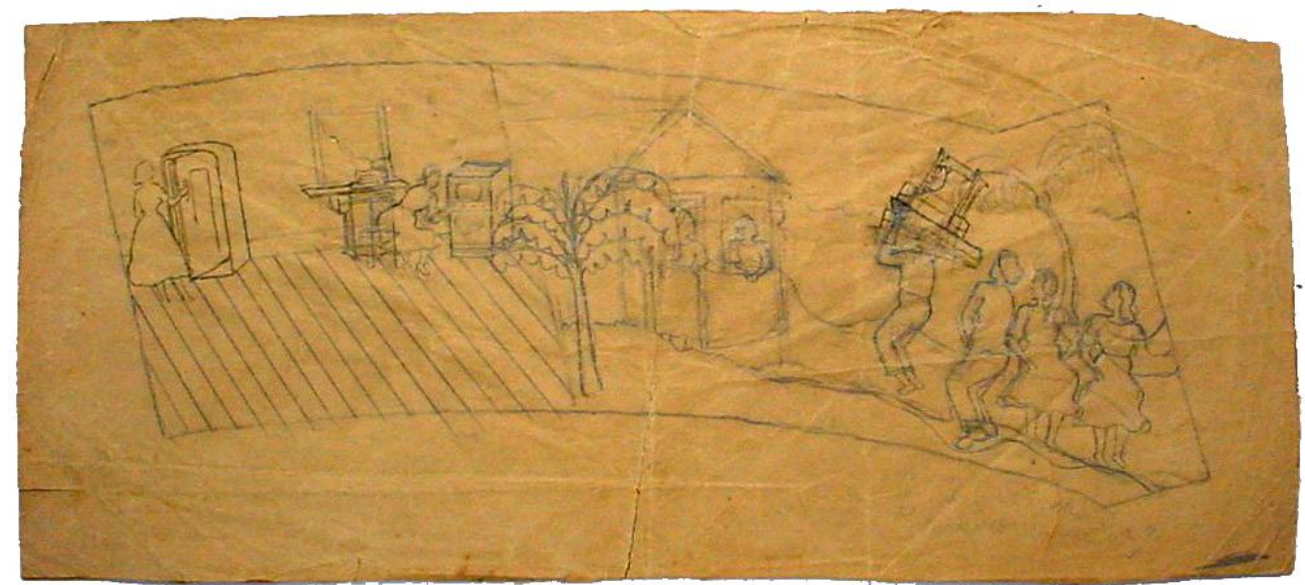

Mudança da cidade para o morro, grafite sobre papel, colado num suporte, $22,0 \times 49,7 \mathrm{~cm}$. MNBA, RJ, sem data.

Tanto nos esboços do acervo do Museu Nacional de Belas Artes, quanto nos desenhos em nanquim para o convite de casamento de Dona Zica com o sambista Cartola e para a imagem de divulgação do bar ZiCartola, notamos a preocupação do artista com a linha enxuta, com a minúcia de detalhes a preencher vazios sem o uso de recursos de luz e sombra. No caso dos desenhos a nanquim, a presença de elementos decorativos florais e de fitas entrelaçadas reproduz o estilo de ornamentos dos desenhos para bordar tecidos. 
$\mathrm{Na}$ década de 40, incentivado por Carlos Cavalcanti e Augusto Rodrigues (Recife, 1913 - Resende, 1993) - um dos fundadores da Escolinha de Arte Brasil -, Prazeres investiu profissionalmente na pintura, retratando cenas cotidianas do Rio de Janeiro e cenários rurais.

\subsection{Moenda e as Bienais}

No período compreendendo entre os fins dos anos 30 e toda década de 40, Heitor na maioria das vezes utilizou o guache sobre cartão, e podemos observar seu universo particular se expandindo para as cenas rurais, demonstrando uma visível mudança nos tons de sua paleta; os verdes são mais luminosos, e os amarelos, azuis e vermelhos surgem com intensidade.

Um importante exemplo desse olhar para o campo é criado na década de 1950, mais precisamente em 1951. Trata-se do premiado óleo sobre tela Moenda. Apesar de o artista afirmar em depoimento que pintava somente aquilo que já vira, as cenas rurais guardam distância do Rio de Janeiro urbano vivido por ele.

Entretanto, não podemos nos esquecer do Brasil "essencialmente rural", nas palavras de Rubem Braga, que era motivo de interesse para o pintor. 


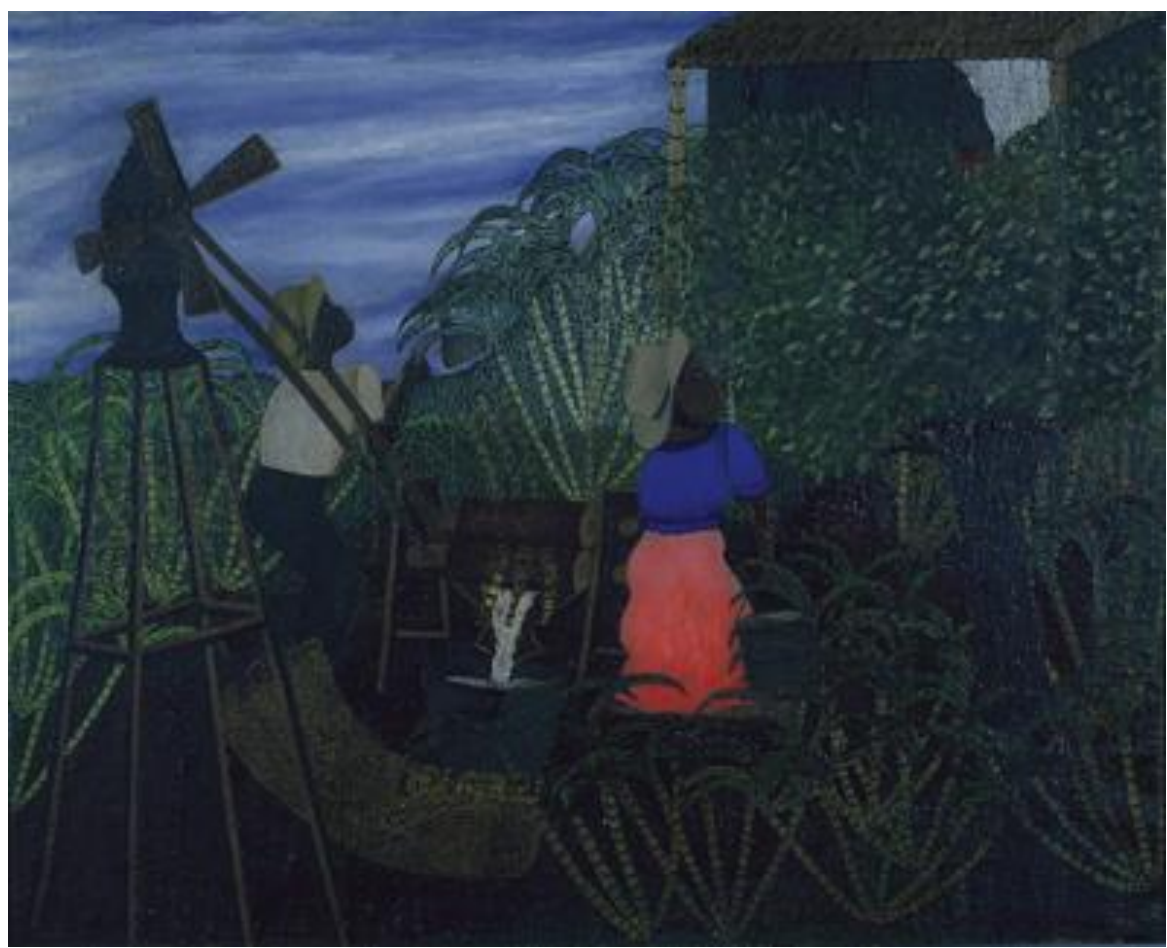

Moenda, 1951, óleo sobre tela, 65x81,1 cm. MAC-USP.

A pintura de 1951 teve participação na primeira Bienal de São Paulo e recebeu o prêmio Toddy de Aquisição, figurando com o terceiro lugar e colaborando para a consagração e inserção definitiva de Heitor no contexto da pintura brasileira.Além de ter sua obra premiada nessa primeira Bienal, Heitor também expôs os trabalhos Calango e Feira Livre.

A obra é um marco importante na visualidade da auto-representação do trabalho realizado pelos negros brasileiros. Sua poética investe numa qualidade temporal e contemplativa dos trabalhadores, tanto do homem quanto da mulher, que parecem imersos em seu próprio tempo, donos da terra e de si mesmos na pesada lida da lavoura de cana de açúcar, símbolo do poderio dos tempos coloniais e fonte dos martírios impostos à mão de obra escravizada oriunda do continente africano. 


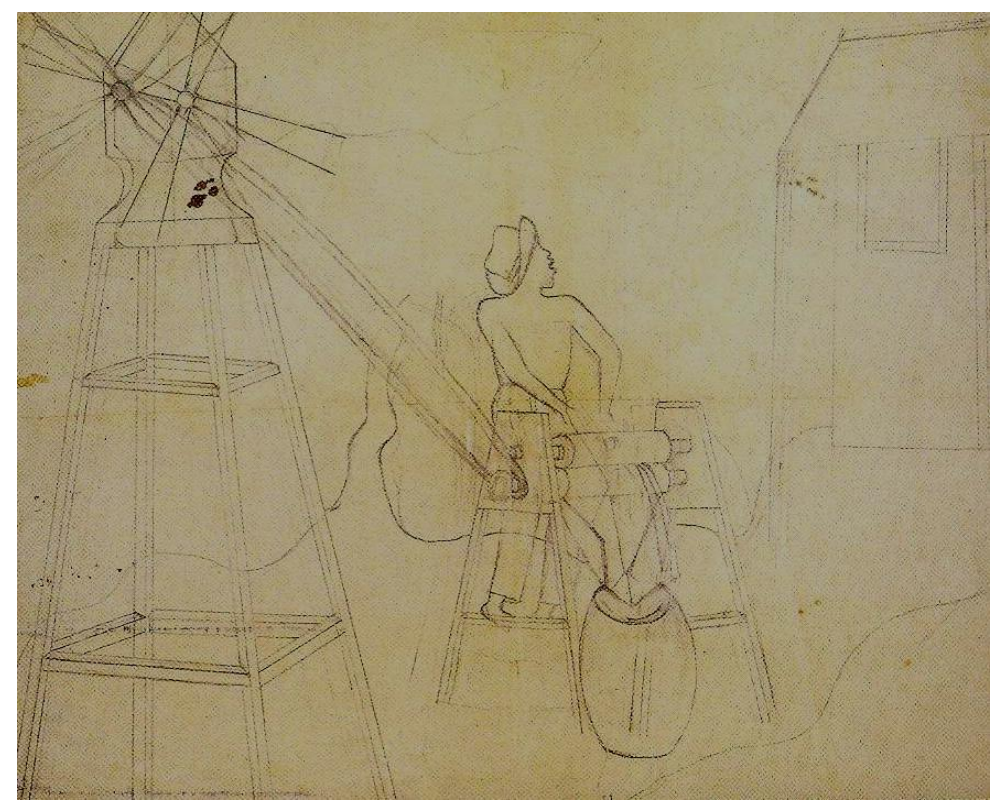

Estudo para o quadro Moenda, década de 50, desenho, 49x59 cm. Coleção da família.

Não há traços de sofrimento ou de dominação na imagem, tampouco de melancolia devido ao abandono que a mão de obra negra sofreu após a tardia abolição da escravidão em nosso país. Diferente disso é o que podemos ver na prancha do livro Viagem Pitoresca ao Brasil (1834), de Jean-Baptiste Debret, que retrata o período colonial, em que o fruto do trabalho desses homens não será exclusivamente seu, haja vista que nem seu corpo é de propriedade sua; a imagem denuncia um movimento extenuante, infindável, a devorar o esforço de homens num labor sem fim:

[...] O lugar de maior perigo que há no engenho é o da moenda, porque, se por desgraça a escrava que mete a cana entre os eixos, ou por força do sono, ou por cansada, ou por qualquer outro descuido, meteu desatentamente a mão mais adiante do que devia, arrisca-se a passar moída entre os eixos, se lhe não cortarem a mão ou o braço apanhado, tendo para isso junto da moenda um facão, ou não forem tão ligeiros em fazer parar a moenda. ${ }^{109}$

109 Neves, Maria de Fátima Rodrigues das. Documentos sobre a escravidão do Brasil. São Paulo: Contexto, 1996, p. 30. 


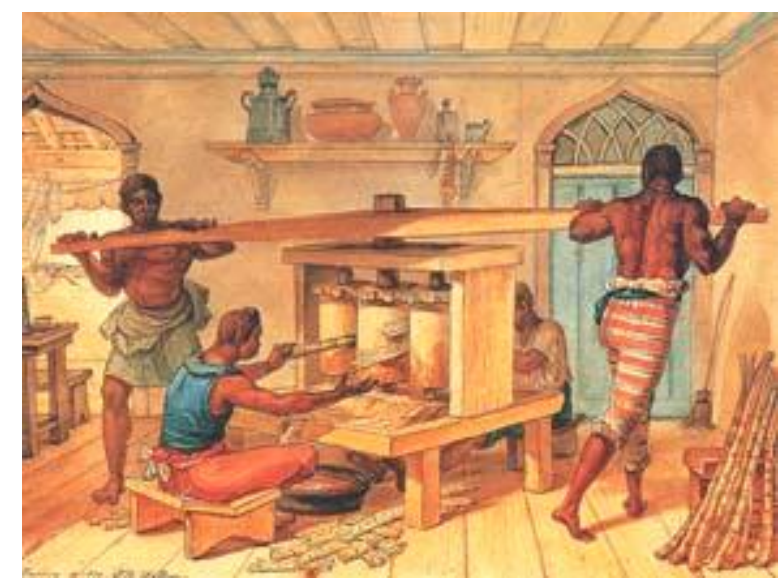

Debret, Jean-Baptiste, Pequena moenda portátil, aquarela, em Viagem pitoresca ao Brasil, 1834.

Em Moenda, o otimismo alimenta o trabalho; não há marcas de sofrimento, mas sim de dignidade e de uma ocupação libertadora, embora se trate do pesado trabalho na roça e no processamento da cana de açúcar. A figura feminina, que não era prevista no estudo, permite-nos imaginar uma união a enunciar a liberdade.

Não há denúncia social nessa pintura simplesmente pelo fato de a desigualdade estar superada. Nesse estágio imaginado, a terra está distribuída igualmente para o usufruto de todos os trabalhadores.

O compartilhar em parceria da plantação e do trato com o produto da lavoura é quase uma representação utópica, dada a situação, na década de 40, do domínio da terra pelos grandes proprietários. O trabalho do negro era substituído pelo do imigrante, sendo que o trabalhador dificilmente era dono daquilo que produzia.

Emprestamos o seguinte conceito de utopia para sustentar nossa leitura:

Não tomamos a palavra "utopia" no sentido de modelos utópicos ou metanarrativas totalizadoras do progresso, mas no sentido de utopias críticas que buscam aquilo que Tom Moylan chama de "expressão sediciosa de mudança social baseada em um processo permanente de imaginar aquilo que ainda não existe". ${ }^{110}$

\footnotetext{
${ }^{110}$ Shohat, Ella; Stam, Robert. Crítica à imagem eurocêntrica. Cosac Naify, 2006, p. 45.
} 
A suavidade e a delicadeza da imagem, rica em detalhes, também diferem bastante da figura melancólica do negro sofrido na lavoura como aparece na pintura Bananal, de Lasar Segall (1891-1957):

[...] Não foi, contudo Segall um pintor cultural, existencialmente brasileiro. (Não se emite com isso nenhuma apreciação pejorativa à sua obra.) Sua arte, decididamente sombria e pessimista não o é à maneira brasileira, temperamental ou sentimental, ingênua ou extrovertida, mas interiorizada, profunda, nutrida numa concepção filosófica do mundo, e essa carga de tristeza se sente mesmo quando os temas de que trata são de natureza risonha ou festiva.

[...] Segall é um grande pintor nostálgico, de uma saudade que vem dos tempos e não de uma lufada de tristeza de uma tarde tropical que nos entorpece $[\ldots] .{ }^{111}$

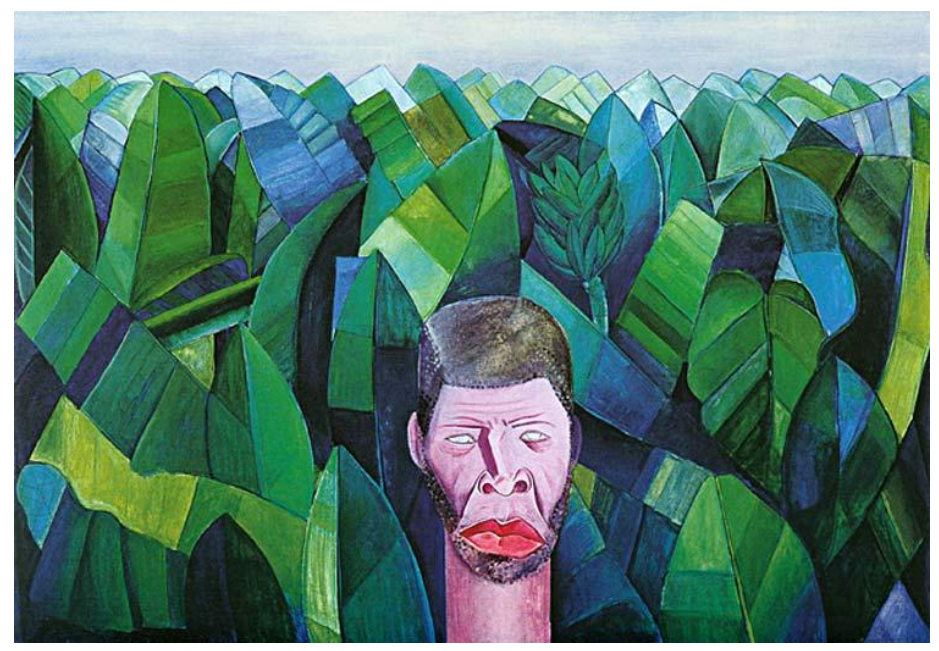

Segall, Lasar, Bananal, 1927, óleo sobre tela, $87 \times 124 \mathrm{~cm}$. Acervo da Pinacoteca do estado de São Paulo.

A pujança do trabalhador oprimido a serviço do progresso do país em $O$ Lavrador de Café, de Cândido Portinari (1903-1962), indica também outro caminho diverso ao de Heitor:

${ }^{111}$ Pedrosa, Mario. Mundo, Homem, Arte em Crise. 2a Edição. São Paulo: Perspectiva, 1986, p. 260-261. 
Cândido Portinari [...] apresenta uma obra cheia de drama humano, no entanto ele também é, na sua pintura, mais espetacular, mais eloqüente, que sombrio ou triste.

[...] Sua vocação era "política", não no sentido estrito da palavra, pois nunca foi um político, mesmo quando se elegeu no duro senador pelo PCB, mas num sentido amplo, de gosto, de convivência, de comércio social, de participação. ${ }^{112}$

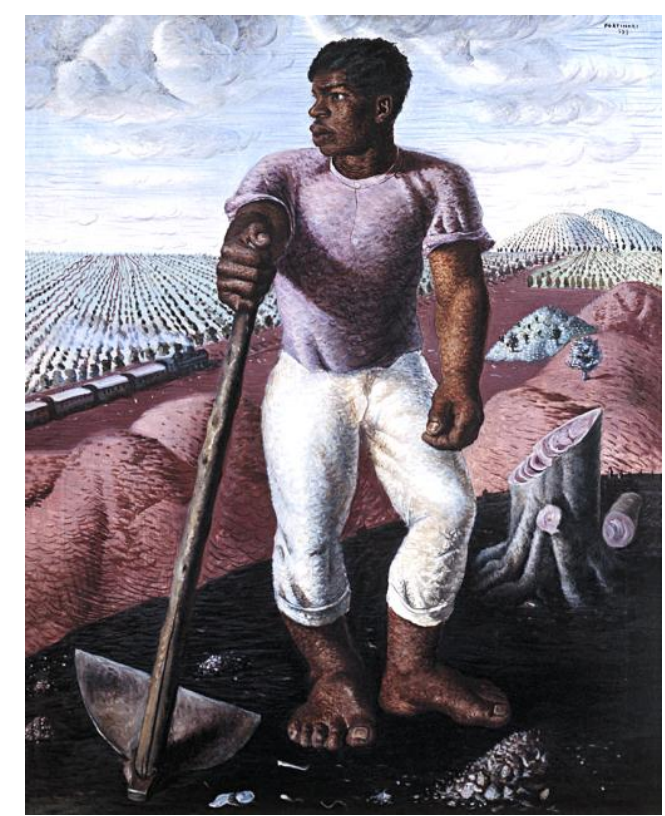

Portinari, Cândido, O lavrador de café, óleo sobre tela, $100 \times 81 \mathrm{~cm}$. MASP.

A novidade na representação do trabalho dessas mãos humanizadas por Heitor provocou fascínio entre os primeiros espectadores da obra, já que o próprio artista, devido à sua origem, poderia ser um daqueles trabalhadores.

Seu otimismo não significa alienação em relação ao estado de coisas, mas um investimento na celebração da vida. Mesmo quando retratava sofrimento, como nas cenas de fugas do morro que veremos mais adiante, a alegria persistia justamente para afirmar a força e a capacidade de resistência das pessoas que ele pintava.

A premiação na Bienal de 1951 foi considerada pelo próprio artista como um marco em sua carreira, pois, apesar de já receber reconhecimento e participar de diversas exposições, aquela consagração consolidou sua carreira - agora, além de músico, como pintor.

\footnotetext{
${ }^{112}$ Ibidem, p. 261-262.
} 
Confesso que não esperava ser premiado. Sabia que ia competir com artistas de muito maior projeção e valor do que eu. Por isso, quando soube da notícia de que um dos meus quadros havia sido premiado, experimentei uma grande surpresa, uma das maiores da minha vida. ${ }^{113}$

Sua participação nas Bienais estendeu-se aos anos de 1953, com as pinturas reunidas em sala especial - Choro Carioca, Frevo Pernambucano, Jogo no Barraco e Joguinho em Família -, 1957 - O Guarda-Chuva, de Mignone - e 1961 - As Três Artes, Mulher Abstrata, Pierrot Apaixonado, Os Capoeiras e Os Jogadores de Sinuca.

A primeira Bienal, em que obteve o $3^{\circ}$ prêmio para artistas nacionais, possibilitou ainda mais oportunidades para o artista, que considerava São Paulo a cidade responsável por impulsionar sua produção pictórica. Além das participações nas Bienais de São Paulo, Heitor recebeu um importante convite: colaborar com a produção dos festejos do IV Centenário da cidade - organizado por Ciccilo Matarazzo, também financiador das Bienais -, ao lado de um grupo importante de artistas:

Para Diretor Artístico, a Comissão do IV Centenário escolheu, entre os coreógrafos de fama internacional, Aurélio M. Millos, que havia alcançado significativos êxitos, colaborando com famosas instituições coreográficas de Paris, Berlim, Budapest, Viena, Estocolmo, Madrid, Buenos Aires, etc., e dirigindo as secções de ballet dos maiores teatros italianos, como o Scala de Milão, Ópera de Roma, Festivais de Florença e Veneza. Chegando a São Paulo, a tempo de participar do juri de seleção, Aurélio Millos iniciou os trabalhos de organização do quadro geral do conjunto e os ensaios técnicos. Além dos ballets criados sôbre músicas já existentes de compositores de renome mundial, como Bach, Scarlatti, Mozart, Verdi, J. Strauss, Ravel, Respighi, Villa-Lobos, Strawinski, Béla Bartók, Casella e Jacques Ibert, foram previstas criações sôbre músicas inéditas de Camargo Guarnieri, Souza Lima e Mignone. foram convidados para projetar os cenários e figurinos os pintores Cândido Portinari, Burle-Marx, Anahory, Noêmia Mourão, Quirino da Silva, Lasar Segall, Di Cavalcanti, Aldo Calvo, Irene Ruchti, Clovis Graciano, Heitor dos Prazeres, Oswald de Andrade Filho, Santa Rosa, Toti Scialoja e Flávio de Carvalho. ${ }^{114}$

\footnotetext{
${ }^{113}$ Lírio, Alba; Prazeres Fo, Heitor dos. op. cit., p. 134.

${ }^{114}$ Revista do IV Centenário de São Paulo, publicação oficial dos 400 anos da cidade. Editora Abril, 1954.
} 
A contribuição de Heitor deu-se no espetáculo do terceiro programa:

O GUARDA-CHUVA - Comédia coreográfica em um ato. Argumento de Oswald de Andrade Filho. Música de Francisco Mignone. Coreografia de Aurelio M. Milloss. Cenário e trajes de Heitor dos Prazeres. Criação absoluta para o Ballet do IV Centenário. ${ }^{115}$

Esse espetáculo tornou-se, mais tarde, motivo de uma pintura denominada $O$ Guarda-Chuva, de Mignone, que foi exposta na Bienal de 1957.

A década de 50 alavancou a produção do artista, e o reconhecimento ocasionou sua participação em diversas exposições além das Bienais. No ano de 1956, ele esteve na exposição "50 anos de Paisagem Brasileira”, no Palácio dos Estados do Parque do Ibirapuera; em 1957, em uma mostra itinerante denominada "Arte Moderna no Brasil”, que percorreu países da América do Sul; em 1959, no Rio de Janeiro, em sua primeira mostra individual, realizada na Galeria Gea , seguida pelas exposições, já na década de sessenta na Galeria Sistina em São Paulo em 1961, e no mesmo ano, no MAM do Rio de Janeiro; em 1963, retorna a São Paulo para mostrar obras na Galeria Selearte.No ano seguinte vai para Salvador por intermédio de Jorge Amado expondo na Galeria Quirino e finalmente no ano de 1965, no Museu de Arte do Rio Grande do Sul em Porto Alegre apresenta pinturas sendo a obra Frevo, adquirida para o acervo do museu.

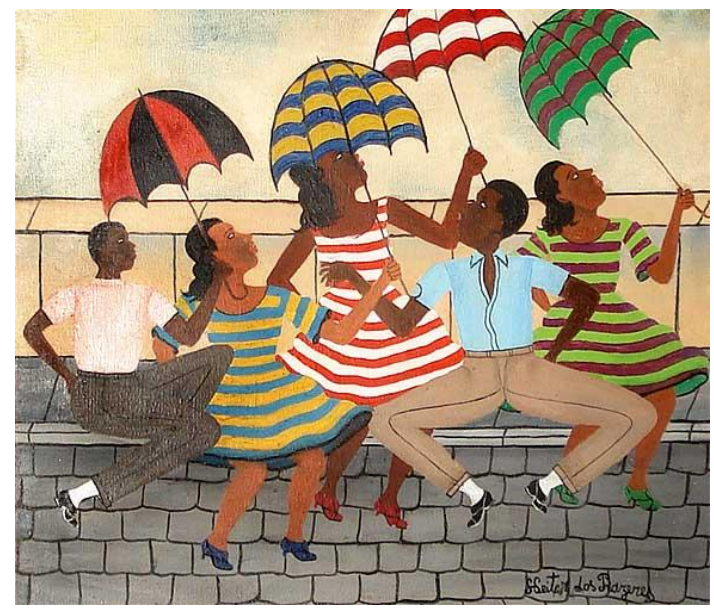

Frevo, sem data, óleo sobre tela 38x46, acervo do MARGS

${ }^{115}$ Ibidem. 
Além das exposições individuais, as coletivas no Brasil e no exterior ocorreram em abundancia e se encontram listadas em anexo ao final de nossa dissertação.

\subsection{Estampas para a Rhodia: Brazilian Look}

Na década de sessenta, exatamente em 1963, Heitor recebe o convite para criar estampas para os tecidos da Rhodia, empresa têxtil que neste período assume papel importante na divulgação da moda brasileira para o mundo. $\mathrm{O}$ convite celebra o fato de Prazeres pertencer ao elenco dos artistas brasileiros reconhecidos como os mais importantes no país:

As idéias de um país eternamente exótico também foram reformuladas (ou aproveitadas) no transcorrer dos anos 1960 pela empresa de fios sintéticos Rhodia, numa associação da arte brasileira à sua matéria prima. A empresa planejou uma ação de marketing integrada, na qual o fabricante desses fios custeava as publicidades das tecelagens que exibiam o selo da marca, expondo padrões de artistas e modelos criados por estilistas brasileiros. Em associação com a companhia aérea VARIG e a Revista Cruzeiro, a Rhodia levava as criações nacionais para serem desfiladas na Europa, nos Estados Unidos e até no Japão

As suas principais coleções anuais e artistas convidados foram:

Em 1 962: Brazilian Nature por Livio Abramo;

Em 1 963: Brazilian Look por Heitor dos Prazeres;

Em 1964: Brazilian Style, Aldemir Martins;

Em 1965: Brazilian Primitive por Isabel Pons;

Em 1966: Brazilian Fashion Team por Hércules Barsotti;

Em 1967: Brazilian Fashion Follies por Willy de Castro. ${ }^{116}$

${ }^{116}$ Neira ,Luz Garcia , A invenção da moda Brasileira, www.eca.usp.br/caligrama/n_10/04_neira.pdf 


\subsection{Músicos,cotidiano e sapatos}

Imagens do cotidiano da Cidade Nova são pretexto para o artista lançar mão da paleta cada vez mais luminosa, mostrando cenas de trabalho, convivência, festas e brincadeiras.

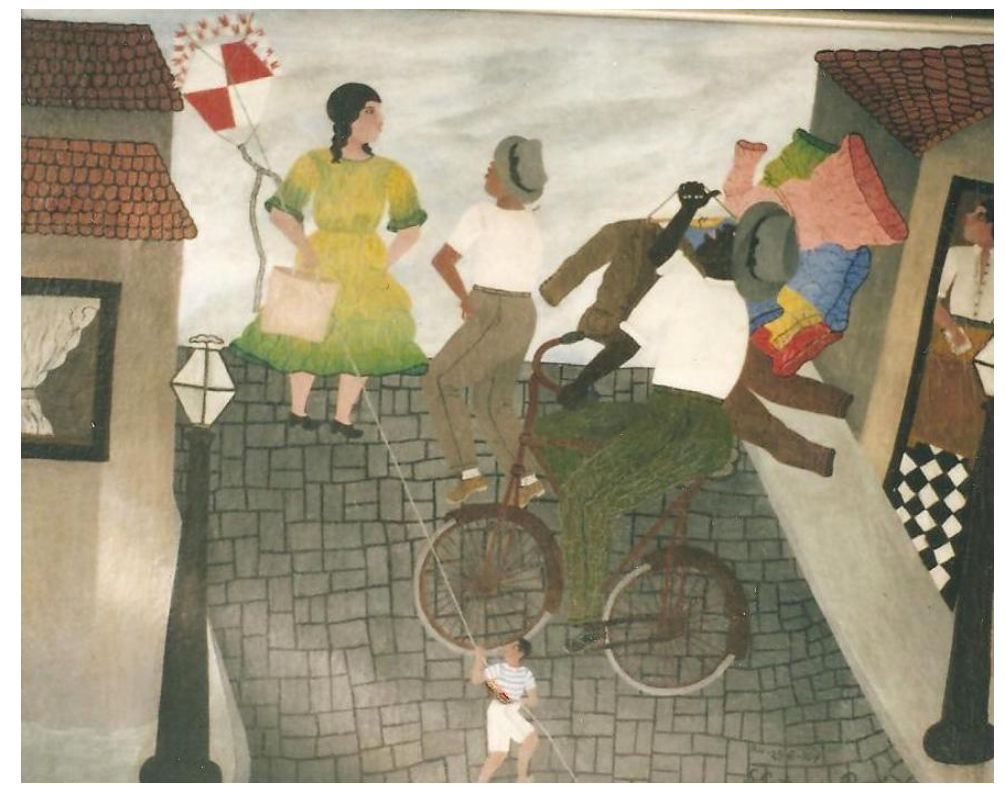

Sem título, óleo sobre tela, 1954, Museu Afro - Brasil

São recorrentes as cenas de músicos em rodas de samba, ora cercados por grupos dançando em outras ocasiões tocando pelas ruas da cidade. Esta temática familiar à realidade de nosso músico, também era representadas por artistas como Portinari, que tinham fascínio pelas figuras populares brasileiras, como os sambistas.

Portinari "executa para a Rádio Tupi do Rio de Janeiro uma série de painéis que tem como tema a música popular" ${ }^{117}$, feitos sob encomenda de Assis Chateaubriand em 1942 para decorar a sede da rádio.

\footnotetext{
${ }^{117}$ Fabris, Annateresa, Candido Portinari : EDUSP, $1^{\text {a }}$ Edição - 1996 p.180
} 
Em 1948, um incêndio destrói seis dos oito painéis que certamente foram vistos por Heitor, que neste período trabalhava na Rádio Nacional e tinha contato com o universo das Rádios importantes contemporâneas a ele.

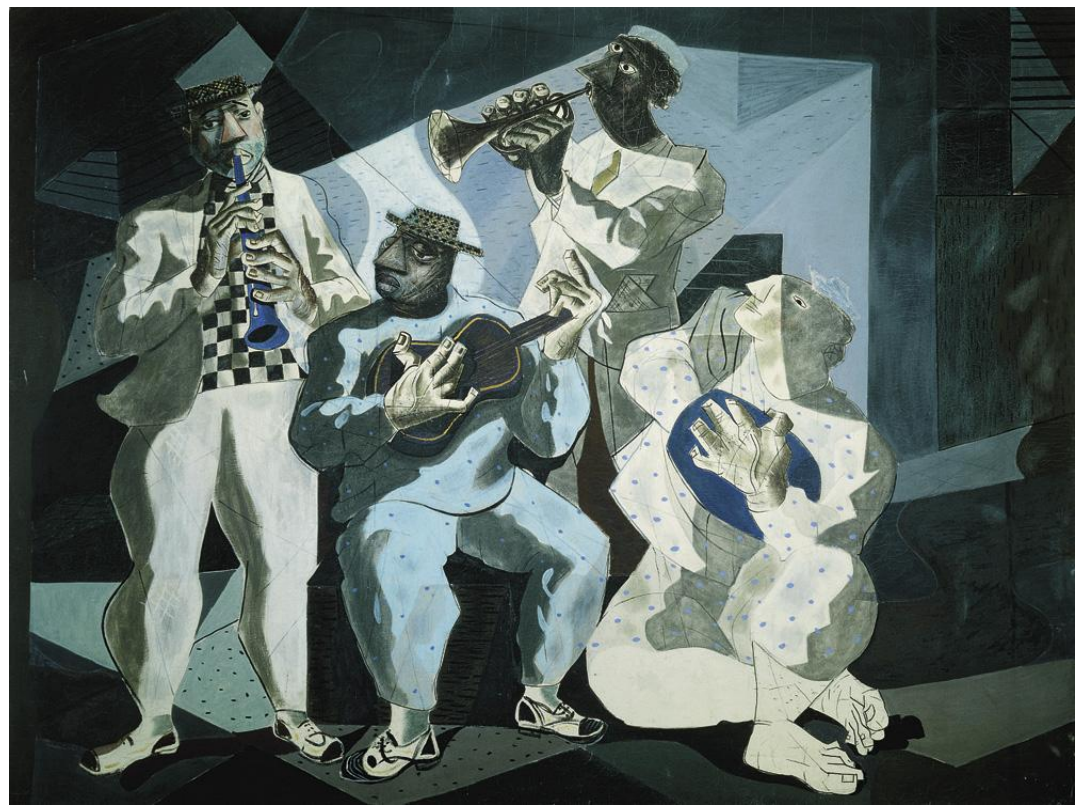

Portinari, Cândido Chorinho, 1942 Painel a têmpera/tela225 x 300 cm Rio de Janeiro, RJ

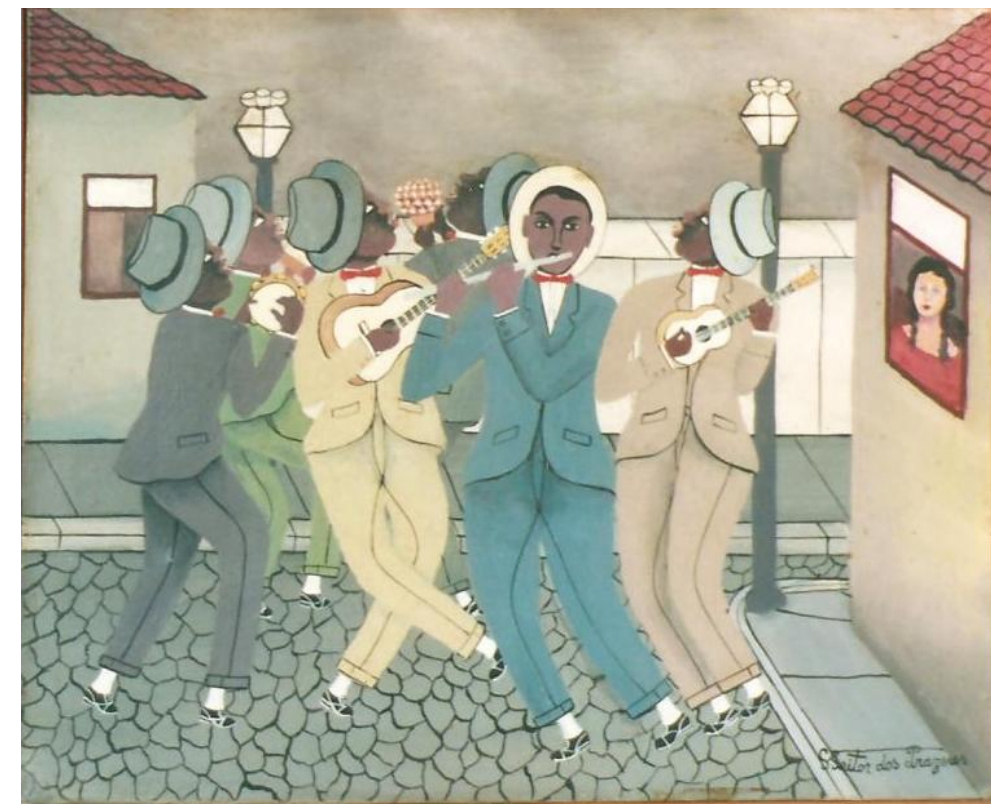

Roda de Samba, óleo sobre tela, sem data, Museu Afro - Brasil

A elegância e delicadeza de traços bem característicos da pintura de Prazeres aparecem principalmente na presença dos músicos e no jogo entre as figuras de perfil e 
o flautista que olha de frente o espectador. Resta-nos imaginar se a troca e influência entre Heitor e os artistas de seu convívio não ocorriam como Clarival chegou a afirmar.

As cores na pintura de Prazeres seguem em direção digamos opostas às cores do painel de Portinari, sendo as cores do último soturnas conferindo um ar de melancolia repetido nos olhares dos instrumentistas e na postura estática de seus corpos, diferentemente dos músicos de Prazeres, que parecem tocar mais alto, dançando nas ruas, admirados pela figura da moça na janela.

Os sapatos que sempre aparecem tão ricamente detalhados nos pés dos sambistas e dançarinos de Heitor em tantas de suas obras, também são vislumbrados nos pés do clarinetista e do tocador de cavaquinho de Portinari, entretanto, o tocador de cuíca descalço jamais figuraria numa imagem de Heitor, pois os sapatos representam liberdade, geralmente um dos primeiros itens comprados por negros alforriados no período da escravidão, onde os sapatos eram vetados aos escravos:

Estar vinculado a uma confraria religiosa, pentear cabelos, usar sapatos, roupas de seda, roupas bem engomadas, usar chapéus, tocar instrumentos musicais de origem européia, fazer uso da escrita e leitura, são exemplos de praticas culturais cotidianas que vivenciadas por negros permitiam uma aproximação com a imagem de civilizados.

Tal questão pode ser compreendida se considerarmos que alguns subalternizados visavam conquistar status semelhante aos que detinham poder, quando se apropriavam de praticas culturais legitimadas como melhores e superiores.Os escravos que fugiam durante a primeira metade do século XIX, na Capital do Império, "procuravam ansiosamente adquirir os símbolos da liberdade, como sapatos, para esconder sua condição real"(Soares,2002,p.83). ${ }^{118}$

${ }^{118}$ CRUZ, M. S.,Nem tudo é valentia ou vadiagem:práticas culturais e usos de símbolos de civilidade por escravos, forros e mestiços na Província do Maranhão oitocentista. Outros Tempos (UEMA. Online), v. 04, p. 16-36, 2007 


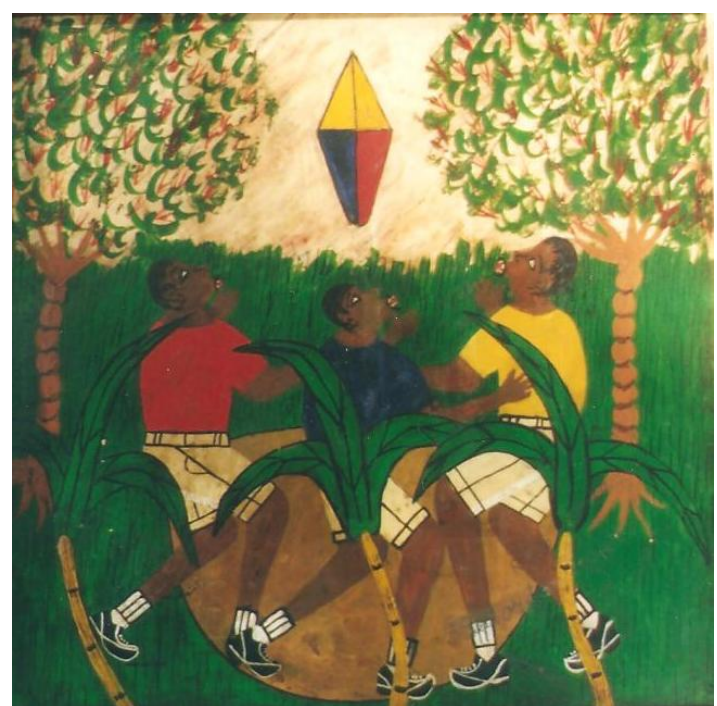

Sem título, óleo sobre tela, 1954, Museu Afro-Brasil

Assim como o menino empina a pipa na rua entre transeuntes e um rapaz que transporta roupas numa bicicleta como desculpa para geometrias e cores vivas, os meninos na roça põem no ar o balão que lembra a mesma forma dos lampiões dos postes das ruas representadas pelo pintor, e a disposição das crianças no quadro assemelha-se aos músicos e dançarinos em outras pinturas.

As cores do balão se repetem nas blusas dos meninos, num jogo poético de cor e movimento onde novamente os personagens aparecem impecavelmente vestidos.

Outro exemplo das figuras emblemáticas de Heitor está em Baile de Rua, que pertence à coleção do filho de Heitor dos Prazeres.

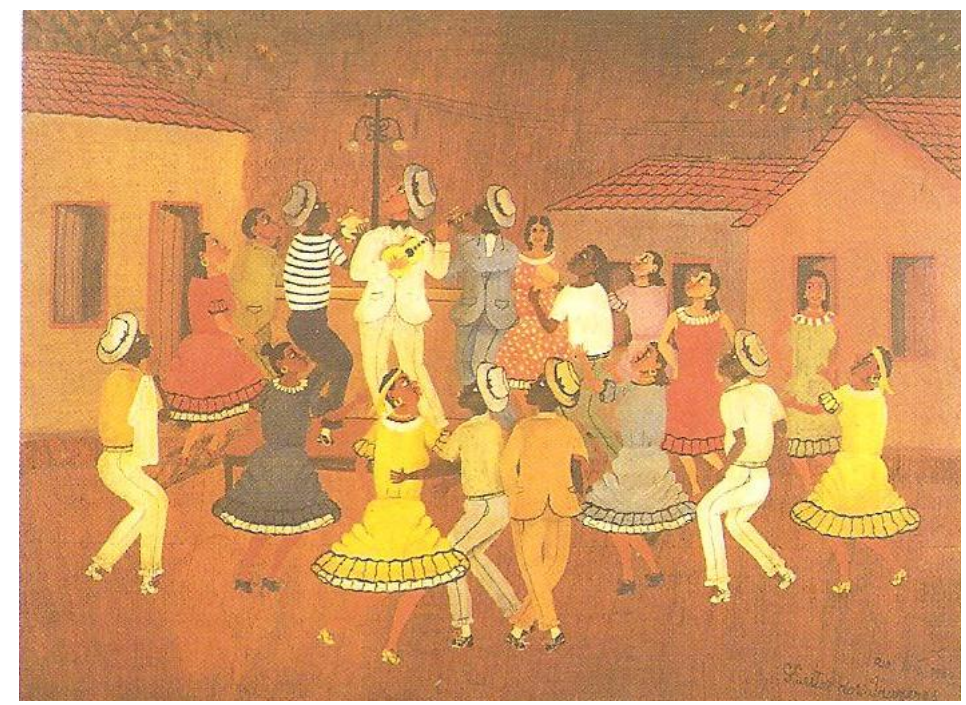

Baile de Rua, 1954, óleo sobre madeira, 49x66cm, coleção da família 
Em Baile de Rua, de 1954, podemos encontrar na disposição das figuras e na minúcia de detalhes, muitos dos elementos consagrados do estilo de Heitor, nos detalhes a seguir e na imagem como um todo, um interessante jogo de formas e cores, e na ordenação triangular dos personagens do baile percebemos a sistemática ordenação geométrica da composição que muitas vezes é semelhante ao triângulo ou a um losango.

O olhar convidativo de duas mulheres na pintura solicita a participação do observador na roda de samba, fato natural para Heitor, pois não era incomum o pintor transformar suas exposições de pintura em grandes festas com música e dança como fez em São Paulo, Rio de Janeiro e na Feira de Arte de Dakar, que o artista participou no último ano de sua vida.

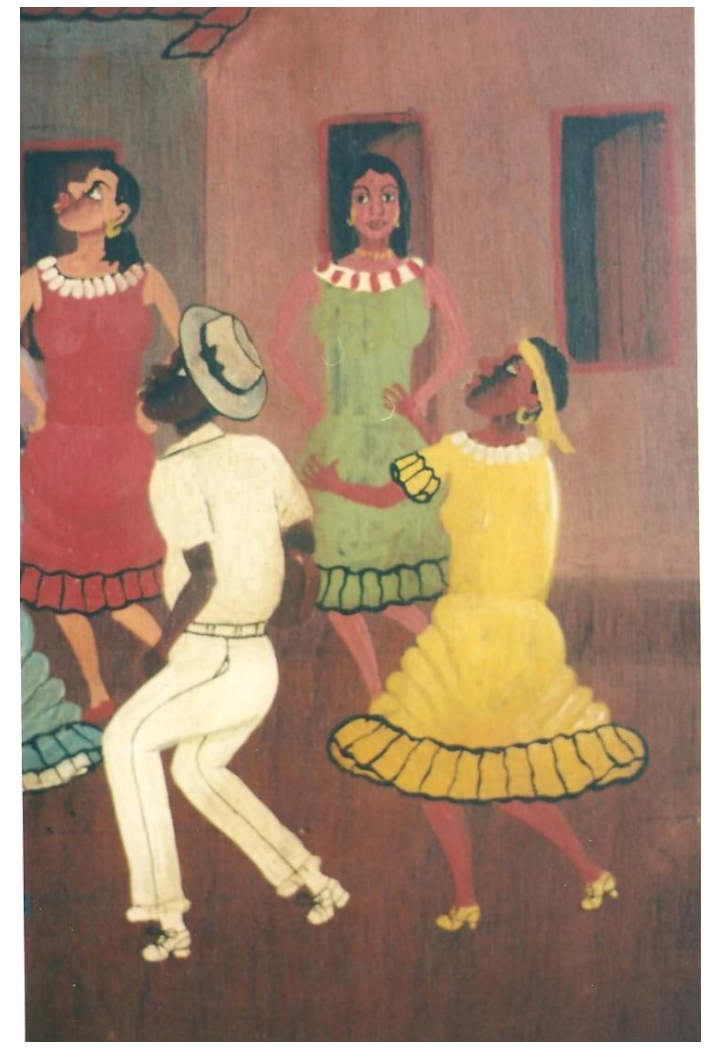

Baile de Rua (detalhe)

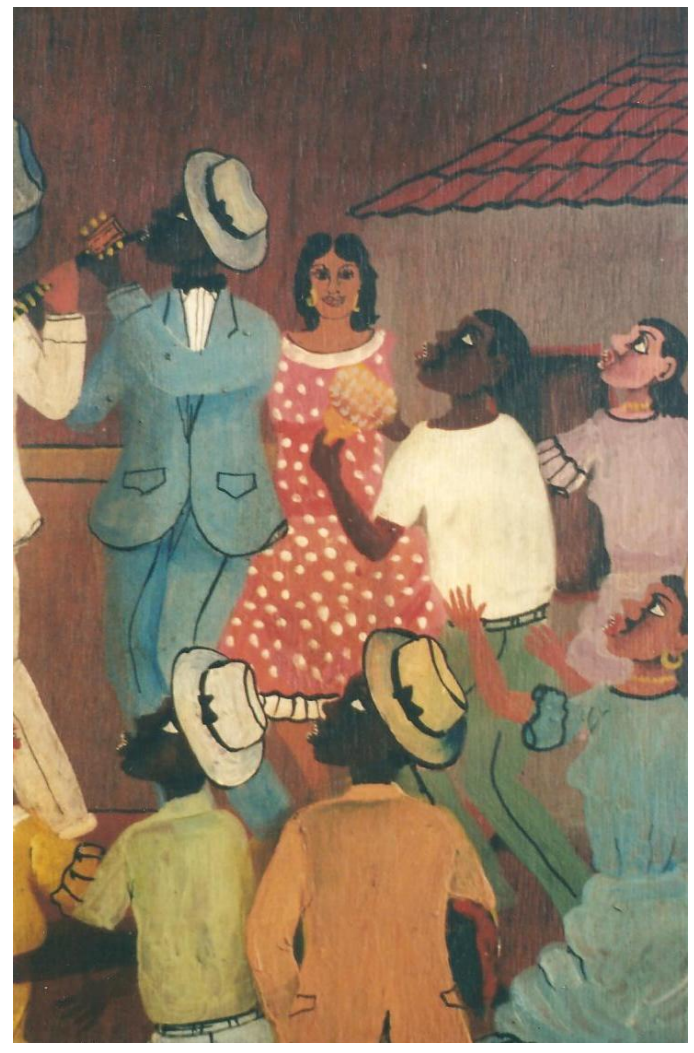

Baile de Rua (detalhe) 


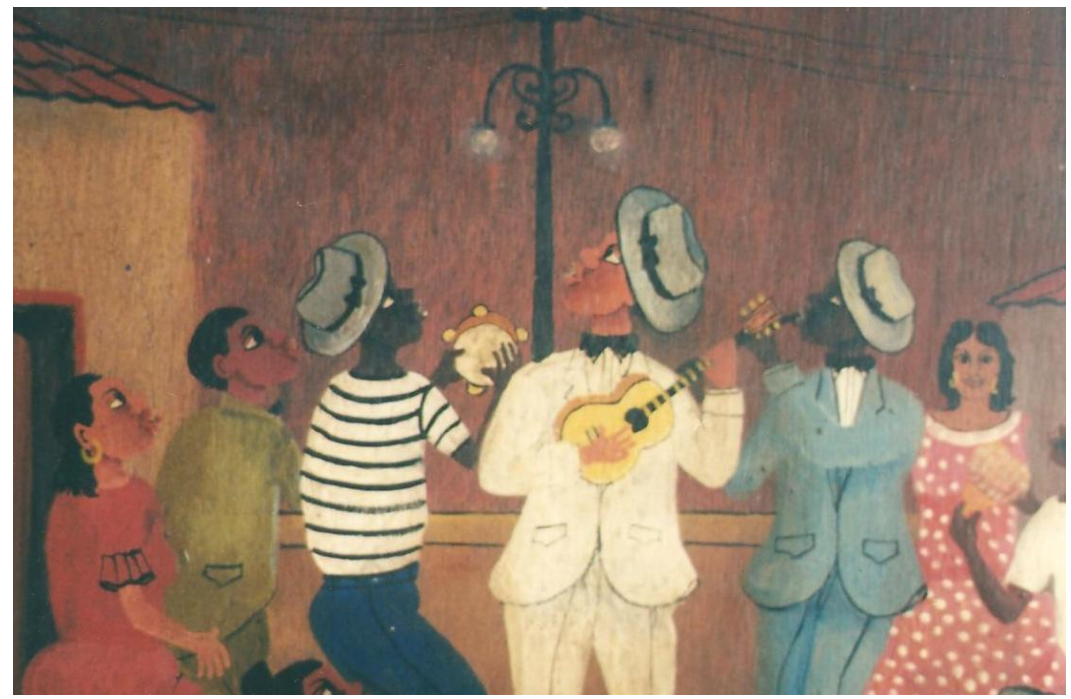

Baile de Rua (detalhe)

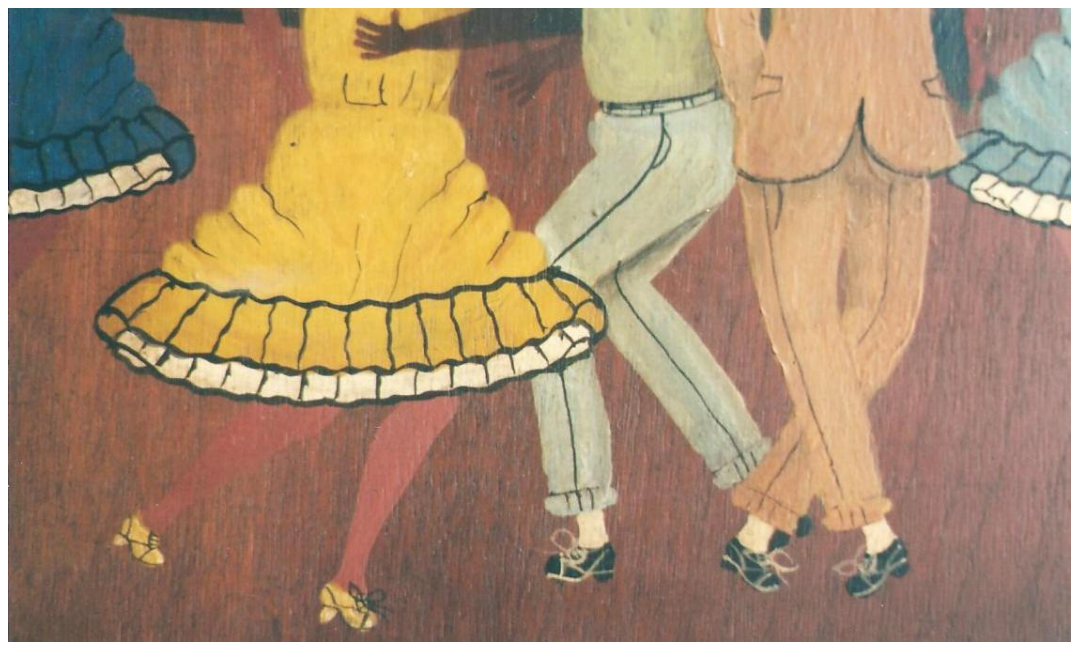

Baile de Rua (detalhe) 


\subsection{Dakar}

A Feira de Arte de Dakar evento que transcorreu de 1 a 24 de Abril de 1966, idealizada pelo consagrado intelectual Leopold Senghor (1906-2001) presidente do Senegal neste período, foi um evento marcante na vida do artista Prazeres, ilustre entre convidados ilustres, como a cantora Clementina de Jesus, o capoeirista Mestre Pastinha, o pintor Rubem Valentim, entre outros, em delegação conduzida por Clarival do Prado Valadares, como vimos anteriormente.

De acordo com o que citamos a respeito da análise de Clarival sobre a pintura de Prazeres, o lema a da Feira de Arte era "Significação da Arte Negra na Vida do Povo e para o Povo", sendo um marco nas relações oficiais entre Brasil e África:

O jornal Dakar Martin registrou, na edição de 30 de março: "(...) Trata-se de algumas personalidades muito conhecidas no Brasil por suas atividades em alguns segmentos, principalmente naqueles dedicados às relações entre Brasil e África, do que ainda sobrevive de cultura africana na América Latina e suas influências sobre a cultura brasileira.. Quase todos participaram do comitê brasileiro no Festival.O Sr. Clarival do Prado Valadares, critico de arte e redator - chefe da revista Cadernos Brasileiros (órgão nacional do Congresso para a Liberdade da Cultura) conduz esta delegação e fará parte do júri internacional que vai conferir os prêmios de arte contemporânea.O Sr. Valadares deve também apresentar uma comunicação sobre aspectos da arte afro-brasileira. Ele é autor dos textos biográficos e críticos que dizem respeito aos artistas brasileiros cujas obras participam do confronto.São eles o Srs.Rubem Valentim e Heitor dos Prazeres,pintores, e o escultor Agnaldo dos Santos, morto prematuramente há quatro anos"119

Meses depois, em 24 de outubro do mesmo ano, o artista falece vitimado por um câncer no pâncreas, sendo enterrado no Cemitério São Francisco Xavier, mais conhecido como Cemitério do Caju.

\footnotetext{
${ }^{119}$ Alba Lírio, Heitor dos Prazeres sua arte seu tempo, ND Comunicação, RJ, 2003,p.142-143
} 


\section{BIBLIOGRAFIA}

ALENCASTRO, Luis Felipe de, O trato dos viventes: formação do Brasil no Atlântico Sul. São Paulo: Companhia das Letras, 2000; ARAÚJO, Emanoel (org.). A mão afro-brasileira: significado da contribuição artística e histórica. São Paulo: TENENGE, 1988;

ARGAN, Julio Carlo, Arte Moderna. São Paulo: Companhia das Letras, 1992; ARTE da África. Org.Peter Jung/Alfons Hug,CCBB,2003;

BARBOSA, Wilson do Nascimento Barbosa, Cultura negra e dominação. São Leopoldo: Unisinos,2002;

BASTIDE, Roger, Arte e sociedade. São Paulo: Companhia Editora Nacional, EDUSP, 1971;

BECARI, Vera d'Horta, Lasar Segall e o modernismo paulista. São Paulo:Brasiliense,1984;

BELTING, Hans, O fim da história da Arte. São Paulo: Cosac Naify,2006; BOSI, Alfredo, Cultura Brasileira, Temas e Situações. São Paulo: Ática, 2006; BRAGA, Rubem, Três Primitivos. Ministério da Educação, 1953;

CABRAL, Sergio, As Escolas de Samba do Rio de Janeiro. Petrópolis: Vozes, 1996;

CASCUDO, Luís da Câmara, Civilização e Cultura. São Paulo: Global, 2004; CONDURU, Roberto, Arte Afro-Brasileira. Belo Horizonte: C/Arte, 2007; CRUZ, M. S., Nem tudo é valentia ou vadiagem: práticas culturais e usos de símbolos de civilidade por escravos, forros e mestiços na Província do Maranhão oitocentista. Outros Tempos (UEMA. Online), v. 04, 2007; DAMATTA, Roberto, Carnavais, malandros e heróis: para uma sociologia do 
dilema Brasileiro.Rio de Janeiro: Rocco,1997;

DURAND, José Carlos, Arte, privilégio e distinção. São Paulo:

Perspectiva,1989;

SHOHAT Ella e STAM, Robert, Crítica da imagem eurocêntrica. São Paulo:

Cosac Naify,2006;

FREYRE, Gilberto, Casa Grande e Senzala. São Paulo: Global, 2006;

GULLAR, Ferreira, Cultura Posta em questão - Vanguarda e

Subdesenvolvimento. Rio de Janeiro: José Olympio,

2006; Belo Horizonte: UFMG, 2008;

HALL, Stuart, Da diáspora-Identidade e mediações culturais. Org.Liv Sovick Belo Horizonte: UFMG, 2008;

HARRISON, Charles... (et alii), Primitivismo, Cubismo e Abstração. São Paulo: Cosac \& Naify Edições, 1998;

JEUDY, Henri Pierre e JACQUES, Paola Berenstein (org.), Corpos e cenários urbanos.Salvador:EDUFBA,2006 ;

LEITE, José Roberto Teixeira, Pintores negros do oitocentos.São Paulo:MWM Ltda.,1988;

LIMA, Marisa Alvarez, Marginália: arte e cultura na "idade da pedrada". Rio de Janeiro:Aeroplano,2002;

LÍRIO, Alba (org.), Heitor dos Prazeres - Sua arte e seu tempo. Rio de Janeiro:ND Comunicação, 2003;

MICELI, Sergio, Intelectuais à Brasileira. São Paulo: Companhia das Letras, 2001;

MOREL, Edmar,A revolta da chibata.Rio de Janeiro:Graal,1986; MOSTRA do Redescobrimento: arte afro-brasileira. Org.Nelson Aguilar. São 
Paulo: Associação Brasil 500 Anos Artes Visuais, 2000 ;

MOURA, Clóvis, Rebeliões da Senzala. Porto Alegre: Mercado Aberto, 1988;

MOURA, Roberto, Tia Ciata e a Pequena África do Rio de Janeiro. Rio de

Janeiro: Funarte,1983;

NABUCO, Joaquim, O Abolicionismo. Rio de Janeiro: Nova Fronteira; São

Paulo: Publifolha, 2000;

NEVES, Maria de Fátima Rodrigues das, Documentos sobre a escravidão no Brasil. São Paulo: Contexto, 1996;

OITICICA, Hélio, Aspiro ao Grande Labirinto. Rio de Janeiro: Rocco, 1986;

ORTIZ, Renato, Cultura Brasileira \& Identidade Nacional.

São Paulo: Brasiliense, 2006;

PEDROSA, Mario, Mundo, Homem, Arte em Crise. São

Paulo: Perspectiva, 1986;

PINSKY, Jaime, Escravidão no Brasil. São Paulo: Contexto, 1993;

PRANDI, Reginaldo, Mitologia dos orixás. São Paulo: Companhia das

Letras, 2001;

RAMOS, Arthur, O folclore do Negro brasileiro. São Paulo: Livraria Martins. Fontes Ltda., 2007;

REIS, João José, Domingos Sodré, um sacerdote africano: escravidão, liberdade e candomblé na Bahia do século XIX.São Paulo:Companhia das Letras,2008; RIBEIRO, Darcy, Os Brasileiros I Teoria do Brasil. Petrópolis, Vozes, 1978; RIO, João do, As religiões do Rio. Rio de Janeiro: José Olympio, 2006;

ROCHA, Agenor Miranda, Caminhos de Odu:os odus do jogo de búzios, com seus caminhos, ebós mitos e significados, conforme ensinamentos escritos por Agenor Miranda Rocha em 1928 e por ele mesmo revistos em 1998/organização 
de Reginaldo Prandi.Rio de Janeiro:Pallas,2003;

RODRIGUES, Nina, Os Africanos no Brasil. São Paulo:Companhia Editora Nacional, 1932;

SALOMÃO, Waly, Hélio Oiticica: Qual é o parangolé?e outros escritos. Rio de Janeiro: Rocco, 2003;

SILVA, Erminia, Circo-teatro: Benjamin de Oliveira e a teatralidade circense no Brasil.São Paulo:Altana,2007;

SOARES, Luiz Carlos, O "Povo de Cam” na Capital do Brasil: A Escravidão Urbana no Rio de Janeiro do Século XIX. Rio de Janeiro: Faperj-7 Letras, 2007; SODRÉ, Jaime, A influência da religião Afro-Brasileira na obra escultórica de Mestre Didi. Salvador, EDUFBA, 2006;

TINHORÃO, José Ramos, Cultura Popular, temas e questões. São Paulo: 34,2001 ; A Música Popular no Romance Brasileiro (vol.II: século XX [1 ${ }^{a}$ parte]).São Paulo: 34,2000;

VIANNA, Hermano, O Mistério do Samba. Rio de Janeiro: Jorge Zahar.Ed.UFRJ, 2004 


\section{ANEXOS}

\section{Anexo 1}

\section{Exposições de Heitor dos Prazeres:}

\section{Individuais}

1959 - Rio de Janeiro RJ - Individual, na Galeria Gea

1961 - Rio de Janeiro RJ - Individual, no MAM/RJ

1961 - São Paulo SP - Heitor dos Prazeres: pinturas, na Galeria Sistina

1963 - São Paulo SP - Individual, na Galeria Selearte

1964 - Salvador BA - Individual, na Galeria Quirino

1965 - Porto Alegre RS - Individual, no Margs

\section{Coletivas}

1944 - Belo Horizonte MG - Exposição de Arte Moderna, no MAP

ca.1946 - Londres (Inglaterra) - Mostra em homenagem à Real Força Aérea Britânica - um de seus quadros é adquirido pela Rainha Elizabeth

1951 - São Paulo SP - $1^{a}$ Bienal Internacional de São Paulo, no Pavilhão do Trianon - $3^{\circ}$ prêmio

1952 - Rio de Janeiro RJ - Exposição de Artistas Brasileiros, no MAM/RJ

1953 - São Paulo SP - 2a Bienal Internacional de São Paulo, no Pavilhão dos Estados

1954 - São Paulo SP - Arte Contemporânea: exposição do acervo do Museu de Arte Moderna de São Paulo, no MAM/SP

1957 - Buenos Aires (Argentina) - Arte Moderna no Brasil, no Museo de Arte Moderno

1957 - Lima (Peru) - Arte Moderna no Brasil, no Museo de Arte de Lima

1957 - Rosario (Argentina) - Arte Moderna no Brasil, no Museo Municipal de Bellas Artes Juan B. Castagnino 


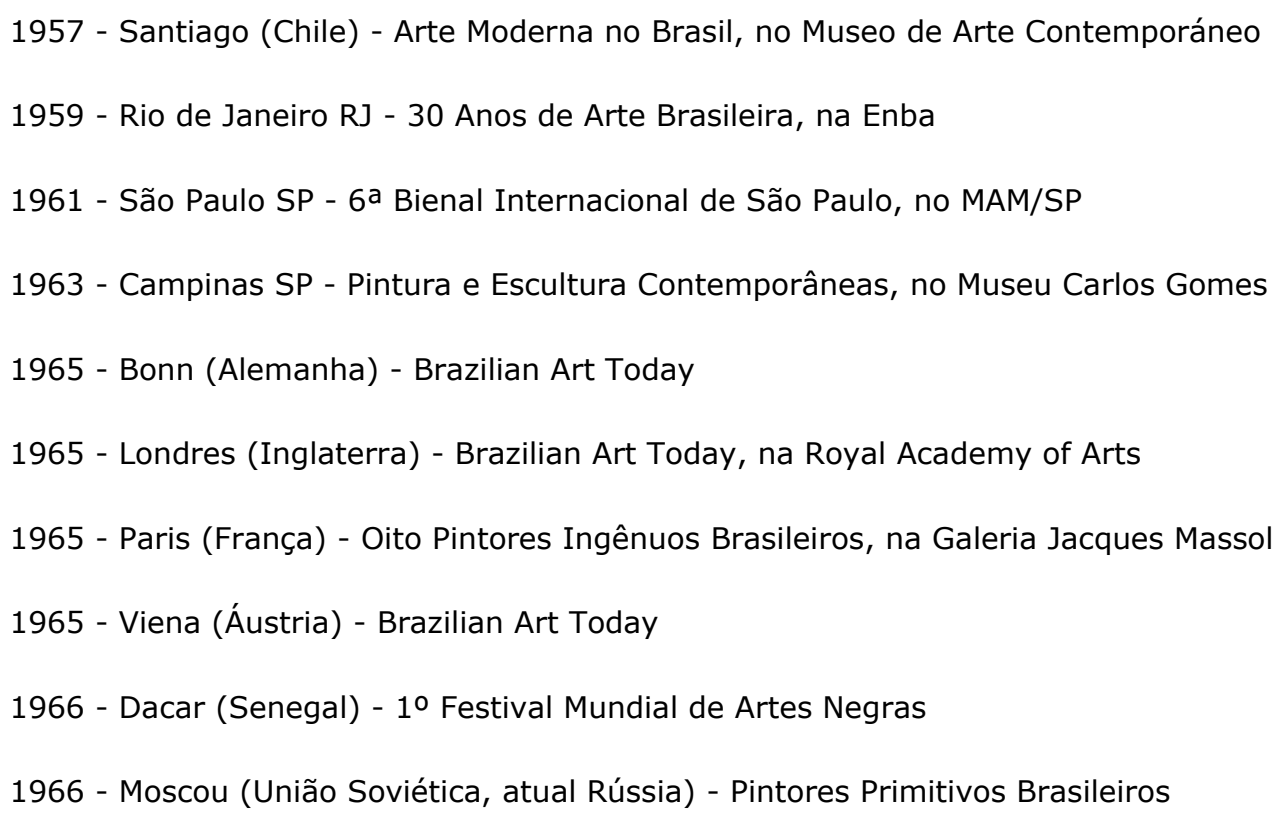

\section{Póstumas}

1966 - Dacar (Senegal) - 10 Festival Mundial de Artes Negras

1966 - Rio de Janeiro RJ - Auto-Retratos, na Galeria Ibeu Copacabana

1966 - Rio de Janeiro RJ - O Artista e a Máquina, no MAM/RJ

1966 - São Paulo SP - O Artista e a Máquina, no Masp

1967 - São Paulo SP - Individual, na Galeria Ars Artis

1979 - São Paulo SP - 15a Bienal Internacional de São Paulo, na Fundação Bienal

1980 - Rio de Janeiro RJ - Homenagem a Mário Pedrosa, na Galeria Jean Boghici

1982 - Bauru SP - 80 Anos de Arte Brasileira

1982 - Lisboa (Portugal) - Brasil 60 Anos de Arte Moderna: Coleção Gilberto Chateaubriand, no Centro de Arte Moderna José de Azeredo Perdigão

1982 - Londres (Inglaterra) - Brasil 60 Anos de Arte Moderna: Coleção Gilberto Chateaubriand, na Barbican Art Gallery

1982 - Marília SP - 80 Anos de Arte Brasileira

1982 - São Paulo SP - 80 Anos de Arte Brasileira, no MAB/Faap

1983 - Belo Horizonte MG - 80 Anos de Arte Brasileira, na Fundação Clóvis Salgado. Palácio das Artes

1983 - Campinas SP - 80 Anos de Arte Brasileira, no MACC

1983 - Curitiba PR - 80 Anos de Arte Brasileira, no MAC/PR

1983 - Olinda PE - 2a Exposição da Coleção Abelardo Rodrigues de Artes Plásticas, no MAC/Olinda 1983 - Ribeirão Preto SP - 80 Anos de Arte Brasileira 
1983 - Santo André SP - 80 Anos de Arte Brasileira, na Prefeitura Municipal de Santo André

1984 - Paris (França) - Heitor dos Prazeres: retrospectiva, na Galeria Debret

1984 - Roma (Itália) - Heitor dos Prazeres: retrospectiva, na Embaixada do Brasil na Itália

1987 - São Paulo SP - As Bienais no Acervo do MAC: 1951 a 1985, no MAC/USP

1988 - Rio de Janeiro RJ - Hedonismo: Coleção Gilberto Chateaubriand, na Galeria Edifício Gilberto Chateaubriand

1988 - Rio de Janeiro RJ - O Mundo Fascinante dos Pintores Naïfs, no Paço Imperial

1992 - Poços de Caldas MG - Arte Moderna Brasileira: acervo do Museu de Arte Contemporânea da Universidade de São Paulo, na Casa da Cultura de Poços de Caldas

1994 - Poços de Caldas MG - Coleção Unibanco: exposição comemorativa dos 70 anos de Unibanco, na Casa da Cultura de Poços de Caldas

1995 - Rio de Janeiro RJ - Coleção Unibanco: exposição comemorativa dos 70 anos do Unibanco, no $M A M / R J$

1998 - Rio de Janeiro RJ - Heitor dos Prazeres: um século de arte

1998 - São Paulo SP - Fantasia Brasileira: o balé do IV Centenário, no Sesc Belenzinho

1998 - São Paulo SP - Mostra Comemorativa do Centenário do Artista, na Galeria Albert Einstein

1998 - São Paulo SP - O Colecionador, no MAM/SP

1998 - São Paulo SP - O Moderno e o Contemporâneo na Arte Brasileira: Coleção Gilberto Chateaubriand - MAM/RJ, no Masp

1999 - Rio de Janeiro RJ - As Três Artes de Heitor dos Prazeres, no MNBA

1999 - São Paulo SP - Cotidiano/Arte. O Consumo, no Itaú Cultural

2000 - São Paulo SP - Brasil + 500 Mostra do Redescobrimento, na Fundação Bienal

2001 - São Paulo SP - Figuras e Faces, na A Galeria

2002 - Piracicaba SP - 6a Bienal Naifs do Brasi, no Sesc

2002 - São Paulo SP - Pop Brasil: a arte popular e o popular na arte, no CCBB

2002 - São Paulo SP - Santa Ingenuidade, na Unifieo

2003 - Rio de Janeiro RJ - Arte em Movimento, no Espaço BNDES

2005 - São Paulo SP - Individual, no Espaço Cultural BM\&F

Fonte: www.itaucultural.org.br 


\section{Anexo 2}

\section{Transcrição do depoimento de Heitor dos Prazeres filmado em 1965 por Antônio Carlos da Fontoura, disponível no site www.portacurtas.com.br:}

Eu sou Heitor dos Prazeres. Heitor dos Prazeres é o meu nome. Este prazer que eu tenho no nome é o prazer que eu divido com o povo. Este povo com quem eu reparto este prazer. Este povo que sofre, este povo que trabalha, este povo alegre que eu compartilho a alegria desse povo. A alegria deste povo, o sofrimento deste povo é o que me obriga a trabalhar. É o que me faz transportar para a tela o sofrimento do povo. Este povo que sou eu, um homem do povo. Não há nada mais sublime do que a massa humana. O povo é a massa humana, é a voz do sangue, o povo é a carne humana, o povo é o aconchego, o povo é tudo. Eu para o povo represento um pedaço. Eu sou o ovo e o povo é a chocadeira.

A minha pintura para mim é importante. É uma fuga das minhas dores, das minhas mágoas, do meu sofrimento, das minhas paixões. Eu me sinto num outro mundo, um mundo sofredor, um mundo gozador, um mundo de felicidade. Um mundo feliz. É, a pintura me dá toda essa alegria, me proporciona tudo isso que é riqueza para mim. Na pintura eu sonho, eu sonho música, eu sonho momentos amorosos, eu sonho alegria, enfim, tudo eu sonho, tudo me dá riqueza. Não consigo fazer nada que não existe porque eu não me sinto bem. Estas figuras que eu faço são de coisas que eu já vi, que ainda existem, estes bailes, estas macumbas, estes sambas, estas coisas que existem. Tanto existem que eu sou um dos que existem. Não preciso ver mais, não preciso modelo. Eu tenho tudo aquilo do passado e de agora, dentro da minha memória. 
Não tenho inveja de qualquer atelier em Copacabana, na Tijuca, Ilha do Governador ou outro lugar qualquer grã-fino. A Praça Onze que é o meu negócio. No meu atelier na Praça Onze eu me sinto tão feliz. Me traz recordação da minha infância, me lava a alma aquele apito da Brahma, aquela Brahma que me traz recordação da minha infância, da minha juventude. Me faz lembrar. Me sinto tão feliz como que eu esteja na casa da minha família, a minha família que já não existe mais e outras pessoas mais: tia Ciata e outras pessoas mais.

Eis o motivo de por que me sinto feliz na Praça Onze. Esta Praça Onze que é a Cidade Nova. É o meu bairro, o bairro que eu tenho amizade, vivo em meu coração. O bairro da Praça Onze que é conhecido de Cidade Nova. Cidade Nova, tradicional Cidade Nova, que é a razão que eu me sinto feliz nesse meu atelier. Vendo meus panoramas da favela, da rua General Pedra, lembrando do meu saudoso colégio São Sebastião. É a Praça Onze, é a Cidade Nova. A minha Cidade Nova Eu pinto a cidade antiga porque está dentro de mim. A cidade antiga é uma coisa que ainda tenho na recordação. Ainda tenho dentro de mim, então tenho aquele espírito de coisas antigas, o qual eu transporto para meus quadros. A minha pintura são coisas que passaram por mim e eu passei por elas, na minha infância, na minha juventude, no arrabalde, aí nesse mundo infinito.

Na minha infância existia a cartilha de Felisberto Carvalho, a qual tinha umas ilustrações e aquelas ilustrações apenas é que me seduziam e eu não consegui aprender a ler e escrever até hoje. Porque as ilustrações é que me seduziam e o que me interessava era desenhar, eu coloria aquelas ilustrações. Mas é triste algumas coisas que eu faço, que o destino não me agrada. Coisas que eu faço que tenho amizade, que eu pretendia guardar pra mim. Então vem um, gosta, leva, vem outro, faço outra coisa, vem outro, 
gosta, leva. Então já me sinto já acorrentado, obrigado a fazer comércio de formas que são desagradáveis.

É um sofrimento pro artista, porque já me sinto comercializado. Eu sinto que já estou fracassando, por que? Fracassando por que eu sou obrigado a fazer coisas que não estão na minha vontade por causa do comércio. Eu faço uma coisa que inspiro, a pessoa vem e pede outro igual, depois vem outro e pede outro igual, depois vem outro e pede outro igual, de forma que é uma tristeza. O artista que é obrigado a comercializarse, a atender situações de mercado, vive acorrentado e acaba morrendo não fazendo aquilo que ele quer.

(canção)

Vai, vai, saudade

Saudade voraz

Vai dizer a ela

Que eu não posso mais

Vai, vai, saudade

Me deixa viver em paz

Vai, vai, saudade

Saudade voraz

Vai dizer a ela

Que eu não posso mais

Vai, vai, saudade

Me deixa viver em paz

Eu sou um covarde 


\section{E covarde demais}

Vai, vai, saudade

Me deixa viver em paz

Vai, saudade 


\section{Anexo 3:}

Texto de catálogo de exposição de Heitor dos Prazeres, por Carlos Cavalcanti.

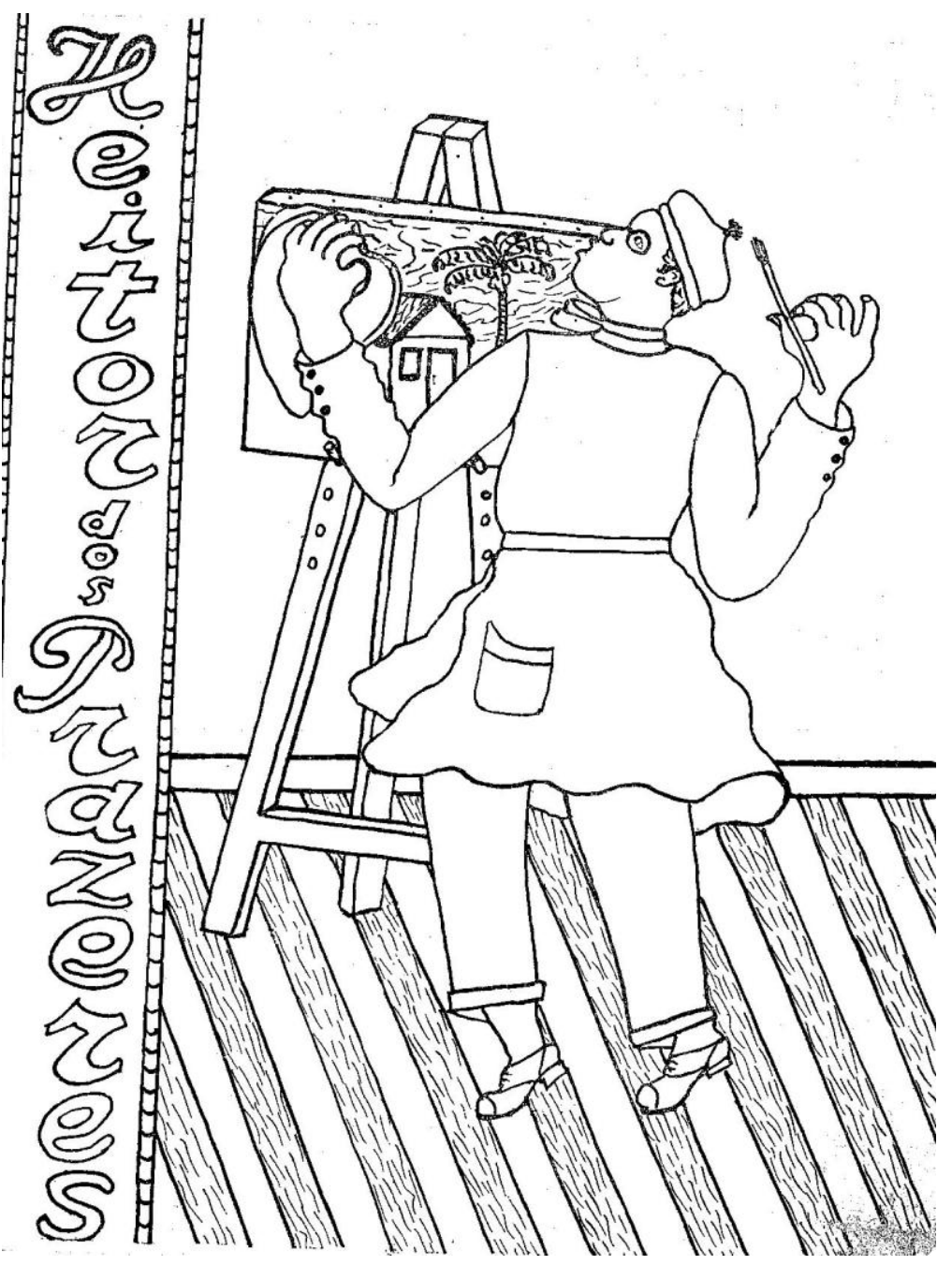

\section{heitor dos prazeres pintura}

museu de arte moderna do rio de janeiro

6 de abril de 1961 
HEITOR DOS PRAZERES

No princípio dêste século, especialmente com o Expressionismo e o Fovismo, acentuou-se o interêsse pelas criações artísticas, livres de preocupações de natureza intelectual, tanto na técnica como na expressão, e reveladoras das camadas mais profundas e elementares da personalidade.

Guando Gauguin dizia pretender voltar não aos cavalos clássicos do Partenon, mas aos rústicos cavalinhos de madeira de sua infância, ou quando Vlaminck afirmava serem suas côres verdadeiros gritos do instinto, estavam revelando novas concepções de pintura, que nos ajudam a compreender o sentido do gôsto atual pelo que poderemos chamar a tradução plástica de puros ritmos de vitalidade.

A espontaneidade lírica e a ausência de intelectualismo das artes das criañcas e dos auto-didatas passaram a interessar não sòmente aos artistas. Também aos estudiosos dos problemas da criação artística. Os pintores populares ou auto-didatas, assim como os artistas negros desconhecidos e negligenciados durante muito tempo pelos preconceitos acadêmicos, tiveram nos princípios dêste século súbita valorização.

Surgiram então os ingênuos pintores de domingo, como os chamam na França. São artistas sem formação escolar e tradição profissional Praticam o amadorismo de fim de semana, como Gauguin no início da sua carreira. Pintam por necessidade irreprimível de expressão criam na mesma disposição de espírito das crianças, isto é, sem preo cupações estéticas na representação da realidade.

Objetivam apenas reproduzíla, com a maior fidelidade possivel, como cbservou Marcel Brion, porque a amam poèticamente por si mesma. Essa fidelidade minuciosa ao real é o desejo de parecerem eruditos iguais aos mestres profissionalmente formados, que admiram e às vêzes procuram imitar.

Apesar dêsses cuidados realistas - alguns ingênuos chegam a medir os modêlos para perfeito verismo da imitacão - 'deformam visionàriamente a realidade pela pureza da sensibilidade e graça natural da imaginação.

Esse mixto de erudição e ingenuidade, aliado ao rudimentarismo da têcnica, confere-lhe às obras valores artísticos especiais. Ao lado de cândida poesia, formas e côres desintelectualizadas e vigoroso sentimento de síntese, que contrasta com a escrupulosa minuciosidade dos detalhes.

Ingênuos, auto-didatas, populares, sempre os houve em todos os tempos. Apenas jamais thes fôra dada a necessária atenção pela conceituação excessivamente intelectual da criação artística. Quando se viu porém, que os elementos permanentes e válidos da criação artística estão mais na área emocional ou instintiva do que na esfera intelec. tual ou racional do homem, passaram à categoria de criadores artís ticos autênticos̃, como as crianças e os selvagens. 
Diferem, porém, dos primitivos. Estes, ao contrário, são dotados de maior elementarismo e simbolismo. Expressam de modo imediato kitmos vitais, delegados das fôrȩas naturais, como já se disse, fundando-se sua expressao plástica em impulsos diretos e profundos isentos? de qualquer intelectualismo. Interpretam mais do que representam. Possuem interesse secundário pela figura humana e deformam a realidade por esquemas mentais, praticando uma pintura de superfície, reduzida a duas dimensões, numa concepção geométrica e, às vêzes, abstrata da imagem visual.

Que a gente se lembre não temos em nossa pintura contemporânea um primitivo autêntico, ao passo que nos últimos anos se multiplicam os ingênuos.

o primeiro foi o celebrado Cardozinho (1861-1942), segundo consta, descoberto por Fujita e Portinari em 1932. Era o nosso "douanier" Rousseau. Participava dos salóes da Associação dos Artistas Brasileiros, no antigo Palace Hotel, expondo sereias na praia de Copacabana, que riam quase exatamente com os trinta e dois dentinhos à mostra. Depois de Cardozinho, aparece Heitor dos Prazeres, por volta de 1937 . Segundo suas próprias palavras rô naseido nesta cidade, na praça Onze, rua Presidente Barroso, é casado, músico compositor de músicas populares e funcionário do Patrimônio Histórico e Artístico do Ministério da Educacão e Cultura, Laboratório de Restauração de Artes, Auxiliar de Restauração.

Já expôs em Londres, Buenos Aires, Nova York e Belo Horizonte. Foi premiado na primeira Bienal de São Paulo, participou da Segunda e das bienais de Veneza e Barcelona, da exposição de radialistas na A.B.I. e na antiga Câmara Municipal e de exposições no Instituto Brasil - Estados Unidos. Em 1959 fêz uma individual na Gea, estêve também no Diretório Acadêmico da Escola de Belas Artes e na prefeitura de Terezópolis.

Fitho de Eduardo dos Prazeres e de Celestina, tendo feito completo - curso primário, é um dos poucos ou talvez o único brasleiro que comemora duas vêzes por ano seu aniversário natalício. Nasceu realmente a 23 de setembro de 1898 , mas sua certidão de nascimento está com a data de 2 de Julho de 1902. A Rádio Nacional, onde trabalha como músico há muito tempo, todos os anos faz uma festa comemorativa no dia 2 de Julho. Mas tarde, no dia 23 de setembro, 0 dia legítimo, como êle diz, comemora-se o acontecimento em casa, com a família e os amigos mais chegados.

Quando nas minhas atrapalhacões de biógrafo perguntei-the qual a data que deveria usar, respondeu: - Bote as duas !

No carnaval de 1932, como musicista popular, obteve o primeiro lugar no concurso oficial, com o seu melodioso e sentido samba-cancão "Mulher de malandro". Foi um sucesso no Rio. A letra dizia:

Mulher de malandro sabe ser

Carinhosa de verdade

Trata dêle com tanto prazer

Quanto mais apanha a êle tem amizade

Longe dêle tem saudades... 
3amais havia pintado, apenas musicado. Em 1937, perdeu a espôsa. Fiquei muito dolente, explica, e comecei a pintar. Viúvo, estava morando num quarto barato da rua do Lavradio, que enchia de desenhos e pinturas a gouache. Dissolvia as tintas de maneira inadequada, às vêzes em querozene. Seus temas iniciais foram os mesmos de hoje - cenas do samba, da macumba e do trabalho rural.

Suas côres eram surdas, intensas e tristes, verdadeiramente telúricas, ao passo que o desenho tinha certa angulosidade, mas fortemente marcado, talvez em virtude dos embaraços próprios ao principiante. Pouco depois estava no meio dos artistas profissionais do pincel. Não faltou quem the quisesse dar conselhos, ensinar-lhe perspectiva, misturar melhor as tintas, levá-lo à Escola de Belas Artes.

Mas, por um sentimento forte, preferiu ficar no seu canto, pintando como as coisas the vêm à cabeça. Escapou dêsse modo ao perigo comum aos ingênuos - o de ficar sabido, aprender certos truques, amaneirar-se, perdendo os valores expressivos.

De suas primeiras pinturas às atuais, o que se poderia notar de mais distinto é um certo senso decorativo do desenho e da composição e maior luminosidade da côr. Estão mais claras e luminosas suas côres e a linha adquire quase sempre um torneio ornamental. Talvez tenha diminuido certo elementarismo, certo teor expressionista, próprio de sua gente, que antes possuia. Contrapõe agora côres primárias vivas e quentes e sem dar-se conta, pois desconhece essas sabedorias, joga excelentemente com as complementares.

Não sei se estará nesta exposição, mas há um gouache grande, filhas de santo dançando numa sala, cortina entreaberta ao lado mostrando o altar, de riqueza linear decorativa e cromática sem igual nos trabalhos anteriores.

A. constância da sua temática, gente do samba e do campo, é um sinal ce sua autenticidade e fidelidade ao meio em que vive. Hoje convive intocado com gente erudita, estetas rabiosos e sofisticados. Só uma vez pintou um nu.

- Onde está? Recife.

- Augusto Rodrigues deu sumiço. Deve estar com Abelardo no

- Por que não pintou mais?

Heitor é sério e cerimonioso. Sorriu: No real...

- É um negócio muito forte. Depois tem que ser no meu jeito.

Outro dia, parecia ter acabado de pintar um samba. $O$ cliente quis levá-lo.

- Não pode, - observou o artista. Está inacabado!

E foi fazer, minuciosamente, um a um, os dentinhos das cabrochas e os ilhozes dos sapatos dos parceiros. No real.

Šeu problema é o real, mas como está longe da realidade o nosso poeta dos sons e das côres. 


\section{Anexo 4}

Textos de Clarival do Prado Valadares para a revista Brasileira de

Cultura, republicados no catálogo da exposição Mostra do Redescobrimento -

Brasil 500 é mais. São Paulo: Associação Brasil 500 anos Artes Virtuais.

\section{O NEGRO BRASILEIRO NAS ARTES PLÁSTICAS}

\begin{abstract}
EXPLICA-SE a modesta presença de artistas brasileiros negros na atual produçăo e promoçàa das chamadas artes plásticas desde que estas se tomaram um atributo de prestigio do estrato socid de nivel econônico mais elevado, no qual os negros numerican mestico, entende-se por ser o nosso mestiç integrante bem assimilado $\mathrm{e}$ indistinto na sociedade "branca".
\end{abstract}

Sendo o Brasil um pais de rigorosa delimitaçâa social sob o critério econômico, e ao mesmo de segregação declarada, a marginalização do individuo se acentua sobre os grupos de economia carente que, em certas áreas, abrange maior número de raça negra e seus

descendentes. A dificuldade imposta aos pretos é a mesma que ocorre aos individuos de qualquaço econômica. Diante dessa correlaçäo de condiçăo racial e de condiçâo de riqueza, negros sâo pouco frequentes nas atividad restritas e sofisticadas dos tratos sociais.

Esta demarcaçăo tornou-se mais incisiva a partir do fim do século dezenove, no correr dos tempo presente, nesta data, quando se aceita como produçåo artística toda a série de atividades, atitudes e coisas decorrentes $d$ anseio de nobiliteçăo, da necessidade de valorizaçâo dos partcipantes da sociedade artesanal e compromisso cultural nas manifestaçóes artisticas.

O território de maior predominância dos pseudoartistas, desprovidos de formaçáa artesanal e qualiade, sao as gajerias particulares das atividade social que cultural. O simples exame das exposiçōes anuais, individuais, dessas galerias, revela-nos a franca predominância de atividade promocional comelata ao prestígio social do

A maior frequeência de oportunidades para artistas identificam a determinado tipo de produção, pernitido e permissão e aplauso se refertent arte primitiva, situada em termos de docilidade, de poeticidade anódina, na dose exata ern que a pintura naiff deve comportar-se no conjunto d privados de aparente clima cultural.

Raros sảo os artistas pretos e mestiços que se afirmam sob criterio critico mais exigente, pois se con que deverá ser ao gosto do consumidor. " ser homem de cor, preto, mulato ou indio, proceden da pobreza, a fim de que a obra seja autêntica pela origem. Isto nâo corresponde a generalidade, mas a uma das características da elite mandatari si mesmos, uma aparência intelectual. Nesta necessidade de valorizaçăo, se tomam consumidores e ditam o gosto, o comportamento, sobre a produçáo coetânea, ou se tornam, eles mesmos, em artistas. Dispondo dos neios proma nobilitaçäo que embora efêmera parece justificar toda a ansiedade e risco.

O participante de elite apela por uma compostura de merecimentos que a natureza formece como casualidade, e ele pretende como disponibifade. dezoito, em pleno escravismo, que năo impediu grande numero de pretos e mesticos ascenderem socialmente através da habilitaçăo artesanal e de sua eventualidade artistica, sempre dependente da qualidade da obra. Quase todos os temas dos povos

Oscar Hurtado assinala que, "nos tempos coloniais, um ofício como a pintura era algo depreciativo, um simples artesanato e que as ordens religiosas trazlam monges decoradores que itizavam as classes hum des, naqueles tempos os mulatos (pardos) e os negros, na instituiçôes. Dessa fase, segundo se deduz, såo Escalera e Escobar"

Acontecimento paralelo ao brasileiro, surgido ao começar o século dezoito e permanecido até os de Marita Alves, referindo-se ao "século XIX que não foi de todo infecundo no tocante à vocaçăo de escultor na Bahia. Apenas notamos que eran mestiços quase todos os artistas imaginánios daquela centuria - cabras pardos - conforme apuramos nos assentos de obito - casamentos". meriente

Hanna Levy aconsetha èxame dos antigos ivros de igrejas e imandades de pretos (Rosáno, Concetçáa e Boa Morte) ao verificar, "pela afimativa de autores competentes, que Leandro e Siva eram de num elenco de 231 pintores, artesăos $e$ artistas do período mencionado, trés que eram escravos, apenas um conhecido pelo proprio nome, Felix, os demais pelo de seus donos. Quase toda produçáa artistica religiosa $m$ setecentos tem a presença $e$ a predominância de mestiços e pretos e, excluindo-se a grande obra destaque a do pintor Manoel da Costa Athayde. artista mulatos.

Francisco Marques dos Santos dá amplas informaçōes sobre o terma'. Sabe-se que Mestre de um fidalgote portugues, contratador de diamantes, e de crioula natural do Brasit"'. Podo se extrair da informação incidental de vários cronistas e historiadores a evidência de que a dependia da boa sorte, de uma eventualidade paternal, ou paternalista.

No ensaio de Antônio da Cunha Barbosa lê-se que "Manoel da Cunha, escravo de meus antepassados, depois de liberto partiu para Lisboa"t, onde foi se aperfeiçoar na sua arte, e no
artigo de Nair Batista sobre pintores do Rio de Janeiro colonial, lê-se que Manuel da Cunha (1737-1809), escravo da familia do Cônego Januáno da Cunha Barbosa, estudou no Brasil e somente conseguiu sua liberdade quando voltou, tornando-se profissional retratista e mestre de pintura em sua própria residéncia'

CESSADA a produção artística coletiva destinada às igrejas e comandada pelas immanidades, os negros e mestiços sofreram reduçáo dessa via século passado, especialmente nas cidades maiores, o artista se definiu naquele capaz de educação dispendiosa, necessariamente no estrangeiro, e de acordo com o gosto dominan

A consequêencia imediata deste procedimento foi a rebaixa do negro para uma margem de afirmaçăo menor. $O$ negro decresce na integração às elites, proporção em que se acentuarm a alienaçäo $e$ sofisticação da sociedade dominante. Os dois ultimos processos levam o braslleiro, particularma obra e autor pela procedência, pelo endereço que the parece civilizaçăo, progresso, valor. Sảo poucos os artistas negros ou mulatos de orige popular entre os profissionais consagrados da tituma melade da centina passada, notadam natraço para as afirmaçőos vocacionais.

FREQUENTES e relevantes săo os mestiços, bern integrados às elites, e autores de obras jâ destituidas de lastro cultural africano, ou afrobrasileiro. Mencionar Jose do Palrocinio, Machado de Assis, Cruz e Souza, Evanisto de Mrrais, Carneiro, Fimino Monteiro, os imaños Timóteo da Costa, eqüivale a recensear homens de cor como valores de uma sociedade branca. Mas, nesta mesma análise, preocupa verificar se os mestiços e negros desta

A sociedade brasileira sofreu nesses oitenta anos de libertação da escravatura profundas alteraçóes em seu complexo etnico, com desvantagem para o negro. O elemento europeu $e$ asiático da inigraçáo continuada ate 1950, a economía organizada dos novos grupos coloniais, a empresarial e a excelente habilidade de ocupaçâo e de fixação, conferiram ao alienigena desses oito decênios imediata superioridade econômica.

Muito pouco se fez, e ficaram improficuas, como iniciativas educacionais, as tentativas de de preparar os libertos, os fithos de escravos nascidos sob a Lei do Ventre Livre, para as profissóes requeridas pela realidade econômica da época. Sabe-se que na Bahia se organizou no ano de 1872 o Liceu de Artes e Oficios sob a preocupaçăo de educar e habilitar os libertos pel

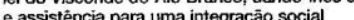
satisfatória, mediante habilitacắa profission diferenciada e, mais ainda, a opçāo de uma educação mais avançada, humanistica, capaz de integrá-los como artistas criadores. 
Uma verdadeira elite de homens de cor foi produto daquela casa de ensino de artesanato (hicios e artes. Mais notavel, entretanto, foi a

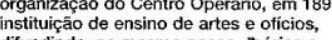
difundindo, ao mesmo passo, tórice praticamente, a instruçāoo, entre seus agremiados e filhos, de ambos os sexos. Instruçâo, eis o termo próprio para indicar o único recurso válido de integração do negro, e mestiço, na sociedade participante. Instruçāo, necessário à formaçäo e afirmaçąąo do individid sem o risco de rebaixa ao nivel da origem.

o Centro Operário, além das finalidades de ensino, tinha beneficência para enfermidade, invalidez, funeral e viuvez. Seus cursos compreendiam o primário, o profissional em trem as matérias de português, francês, aritmética, desenho geométrico, mecânica elementar, perspectiva e teoria da sombra e da luz, álgebra até equação do segundo grau, arquitetura civil, história das Artes, resistência dos materiais e estabilidade das construçōes. O curs profissionat con obra. Os discipulos, de eram obrigados à freqüência de suas oficinas de tipografia, encadernaçâo, marcenaria, carpintaria torneiro, modelador, pedreiro e educador.

os PROcRamas e intençōes dessas entidades não resistiram às distorçōes das últimas décadas. Sofreram esvaziamento das proposiçoes e se operário năo diferenciado. Resta a indagação se as organizaçôes oficiais de finalidades da educaçáo profissional e técnica têm conferido resultados equivalentes, isto $\mathrm{e}$, a eventualidade elites, no mérito de artistas.

A perda daquelas entidades, espontâneas do espirito comunitánio, e sua substituição por organizaçōes de ensino técnico padronizado, diffarno, dem destrivel diferenca nos resultados. Foma-se o op
massificado, tragado pelas atividades profissionais sindicalizadas, ao tempo em que
desaparecem as afirmaçōes individuais. Quando este esvaziamento ocorre numa sociedade pouco participante dos parques industriais, a consequêencia se agrava, permitindo que os resultem em profissōes de salário mínimo. A perd daqueles instrumentos de instruçäo representa, também, a marginalização da sociedade negra $e$ mestiça, insuficientemente afirmada precariamente integrada à civilizaçāo. Sua consequêencia mais aparente é a diminuição. numérica de artistas negros e mulatos nas elementos diminuiram nas camadas elevadas, diferenciadas por qualidade profissional ou condiçãa de riqueza, enquanto permanece crescem e caracterizam o quadro racial das populaçōes faveladas ou de padröes deploráveis.

Desse modo, quando hoje se estuda a presença do negro nas artes brasileiras, logo se percebe inferioridade numérica em relaçăo aos de outras etrias, e a razăo do fenómeno está no fato do comunidades menos participantes do

desenvolvimento. A impossibilidade de se obter, por recenseamento, as densidades étnicas reais, uma vez que o item de raça branca é mais declaraçăo que verificaçăo, condiciona a estimativa de vinte milhōes em número relativo. Mesmo nessa parcela, a incidência de negros nas artes plásticas atuais
CHAMA a atenção a maior presença de negros em outras atividades culturais, artisticas e nos esportes. Musica e futebol são as áreas mais visiveis de sua participação. Como se explica es aspecto identico entre o Brasil e os Estad diferente? Há especulação cientifica que tenta explanar por ser o negro mais dotado de estrutu celular nervosa, referente à junçẫo mio-neural, permitindo-the reação reflexa e comando muscular mais competente. Isto explicaria o sucesso do negro no futebol, no boxe, na dança, no canto, no atletismo, de um lado, e do outro em toda a área de estética criativa visual.

Creio não ser necessário usar de conjeturas pseudo-cientificas da fisiologia para se responder uma simplos indagaçáo que traz outro endereço. à escala de miscegenação, entretanto se iguala como elemento marginalizado, de oportunidades menores, em relação às comunidades prósperas dominadas por outros gnupos raciais. Segregaçâa racial equivale, nos resultados, ao preconceito social-econômico, e mais grave ainda é se constatar que, alem do desnivel social, cosmopolitismo imigratório bern sucedido, indicios e evidencias de exercicios de preconceito racial, assim como se verifica o mesmo comportamento,

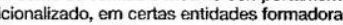
de elites comandatárias.

Voltando ao tema proposto, o negro nas artes plásticas brasileiras, encontramos aparente explicação no paralelo com os Estados Unidos, dimensão históricara a atualidade, porem não en No passado, o negro e o mulato brasileiro tiveram melhores oportunidades de acesso e afirmaçăo implicadas às obras religiosas, dirigidas pelas immandades e confrarias, quando estas correspondiam a sistemas cooperativistas, assistenciais e de controle sobre a categonização

NA HISTÓRIA contemporânea, desses oitenta anos de abolição, a sociedade branca brasileira vai cada vez mais se aproximando dos padrôes características culturais da civilizaçāo norteamericana e o mesmo ocorre em relaçăo à sociedade negra. Só com a diferença de que lá esta última é demarcada por etnia, enquanto entre cultural relevante do comportamento da sociedade brasileira atual é a alienação, cujo espelho sempre se dirige aos centros de predomínio do progresso. A sociedade branca brasileira, embora mestiça, considera-se branca quanto aos padrōes, gostos, hábitos e atítudes cosmopolistimo dominante que muitos confundem com universalidade.

Uma das faces dessa sociedade "universal" hodierna, sectária e situada nas elites, é o seu tip de consumo de arte, desviado do processo de habítaçáo e qualidade, desvirtuado da realid histórica e da finalidade de uso colotivo gar por sua comunicabilidade. $O$ consumo de arte proposto pela sociedade dominante é de caráter privativista, afetivo e promocional, tendo por fundamento a ocupação de dinheiro e tempo ociosos e por finalidade a disputa e a retençăo para seus integrantes daquele crédito que se integrar-se às elites de acordo com sua
competência de lavor e mérito de criaçâ.
Os homens de cor, segregados em comunidades pobres, nâo podem competir com o equiparnento promocional, afetivo, privativista das camadas sofisticadas. Seu instrumento de competição é a instruçâa, aquela expressăo obsessiva de todas as suas organizaçס̄es religiosas e educacionais do passacifica paruç querendo cizer habilitaç conhecimento ampliado, ou pelo menos informado, do humanismo e progresso.

O que mais caracteriza a arte do negro, isto é, a arte negra, aquela que tem a sua perenidade universalnente genuina e que se manifiesta universalmente através das transculturaçôes e
sincretismos, é a sua imensa comunicabilidade. É o seu compromisso ao manifestar-se como sentimento comunitário, como expressividade plural. Os esportes, o atletismo, a música e a dança sáo territorios da emocionalidade coletiva oferecidas pela civilizaçãao, em substituição aus presente com ampla superioriclade e vituosis

Noutras artes, nas artes plásticas convencionais, por exemplo, cujo compromisso de expressividade do sentimento coletivo é, nos tempos de hoje, uma condiça casual e opciona dizer que esteja ausente. A sociedude, nao quer sabe armar o circo de suas exposiç̄es promoçōes, porém, necessita injetar, de tempos em tempos, quotas de validade do contexto histórico e cultural. Estas são as oportunidades
em que artistas negros, hoje com mais frequêtncia em que artistas negros, hoje com mais freqüência procedentes do autodidatismo e do primitivism mimente consumidos pela sociedade "branca". Nem sempre esses artistas negros se expressam
tomo cultura negra. Muitos assimilam rápido as características do estilo em moda e logo se permanecem no vocabulário de origem, ou sabem evoluir na eventualidade de caracteristicas. estilisticas individuais e se afirmam sob o criténio crítico mais rigoroso.

DIANTE da indagaçâo sobre a maior evidência da arte africana genuína na produção artistica do negro brasilero, com exceça dos raros exemplos africana implicada aos rituais do candomblén, na temos outro meio de demonstrá-la senāo no atributo de comunicabifidade, ampla e imediata, que é inerente à estética africana, a ponto de ser

hermetismo e o privatismo sâo qualidades das cufturas brancas, enquanto a comunicabilidade $e$ a participação coletiva são próprias das culturas tribais. O compromisso da obra de arte "branca iniciado que a valorize, conferindo-lhe aceitaçäo feto. Para a obra de arte negra, ela só existiv́ sendo mensurada na emocionalidade colbtiva imediata. Nos exemplos de aculturação do negro em sociedade branca, esses aspectos se comprovarm nitidamente. Explicam a tolerância jesurtica do sincrelismo hagiológico catolico com começo dos Setecentos, a representacăo Virgem, do Menino serafins em modelos de raça negra.

Pouco se divulga da verificaçăo do restaurador Femando Barreto que, tratando a pintura de da lgreja de N. S. do Rosário dos Pretos, recente, datada de 1860 , era de um modelo de uma Senhora branca, italianizada; na segunda,
dos comecos dos Oitocentos. personacem de 
raça branca mas, no original datado de segunda década dos Setecentos, a Senhora e o Menino são figuras da raça negra. Seria emôneo pensar-se século XVIII. Maior era a permissảo da aculturaçấ. católica, como recurso politico de integração $e$ submissão. Uma vez superada a primeira fase do processo de acomodação social, a Senhora acordo com o esquema hieríruico em que negro admitiu o amo no protótipo étnico oposto. Assim entende-se a padroeira dos homens de cor ser uma Senhora branca, pouco antes da data da aboliçāo, provavelmente pintada por artista neg

Ninguém poderá estudar a história da cultura brasileira sem indicar a presença de pardos $\mathrm{e}$ pretos entre os artistas de relevância, sobretudo Lei Aurea. No periodo mais remoto da produção artistica no Brasil, compreendido entre a segund metade do século XVI e todo o século XVII, a autoria negra é pouco denunciada. Explica-se pela do autóctone, fazendo-o número expressivo de seus irmãos leigos artifices das construç̧ốes religiosas. Nāo há evidência de artistas negros educados por jesuitas, naquele periodo.

Dos acervos seiscentistas identificados ou atribuidos a autores, predominam monges $\mathrm{e}$ européia. Discipulos brasileiros destes terian sido mestiços, integrantes de cultura alienigena. 0 século dezoito é o tempo próprio da participaçấ do preto e do pardo, na construção religiosa de

Toda civilizaçāo fundamenta-se no fenômeno social da igreja em mãos do povo, e nāo das ordens religiosas de ação politica e latifundiária. banoco mineiro, excetuando-se os exemplos de um novo parasmetro uni impostos, e o banoco em um novo parametro universal, pelo que ele tem pardos e pretos, mepresentacāo dos santos $\mathrm{E}$ anjos em protótipos negróides, libertação dos cânones e franquia de reformulaçăo dos elementos ornamentais. A emulaçāo das construçóes e 0 incentivo do fulgor na decoraçāo religiosa abre como reter parte do ouro.
colno Se no primeiro período pode-se atribuir a consciência de nação ao trabalho jesuítico, no segundo isto se verifica em mãos da comunidade - negra, mestiça, brasileira, e este o capítulo de nossa história de liderança mineira. Na centúria seguinte, Minas emudece, esvaziada do ouro, silenciada em seus civilizaçâao pastorił na qual o mestiço se indiferenciou. Do ponto de vista estritamente cultural, verificável na produçāo artistica arquitetura, pintura, imaginária e música religiosa, a civilzação mestiça mineira continuou sobretudo em Goiás, cujas obras dos Oito-oeste, estāo mais próximas dos protot dos Setecentos que da Europa da mesma época. E, por esta via, pelo sertanismo pastoril goiano, mantêm-se por mais um século a cultura mestiça, o barroco brasileiro de tipologia européia e de expressividade negra. Este é um confronto, análise e reavaliação, emos de opiniāo suficiente para uma revisăo do barroco universal, por seus aspectos de transculturaçăo.

No OUTRO lado do pais, nas metrópoles e cidades do litoral e do interior próximo, a cultura Nurnerosos artistas negros e mestiços se educavam e se afirmavam nas profissōes tradicionais e nos estilos da civilizaçấo coetânea,
branca, sem compromissos e sem conotaçăo à branca, sem comp
cultura negra.
Ninguém poderá identificar genuinidade ou emanescencia de cultura negra nas obras de João Thimótheo, Arthur Thimótheo de Costa, Horácio Hora, Xisto Valle, Randolfo Bartosa ou nos descendentes negróides que produzem en nossos dias, na identidade da arte internaciona comandada pela civizizaçáo de fora. Do pirtor Armando Viana, a náo ser retratos de provedores Janeiro, incluindo o sey auto-retrato nequel qualidade, que integravarm a valiosa galeria
destruida no incêndio da Igreja em 1967, nada se tem de sinal de raça. De Almir Mavignier, artista pardo nascido no Rio de Janeiro em 1925, residente e bem sucedido na vanguarda européi

mesmo se aplica a J. Garbogini Amaglia, rascido na Bahia em 1928; ou a Barros, "O Mulato", de Porto Alegre; a José de Dorne (Estância, SE, 1921); a Raimundo Oliveira (Feira de Santana 1930 - Salvador 1966); ao gravador Jose Assunçáa de Souza (Recife, 1924); ao pintor e gravador Emanoel Araujo (Bahia 1940); à pintor Yeda Maria; ao gravador-entalhador Edison da Lu (Ba, 1942); ao pintor e gravador Juarez Marialva Paraizo e a vários outros artistas de descendência negra, plenamente afirmados na linguagem
estética cosmopolita. Numa publicaçāo do

estética cosmopolita. Numa publicação do
Ministério das Relaçöes Exteriores, Quem é Quem - Nas Artes e nas Letras do Brasil, editada em 1966 , verifica-se sobre o total de 298 fichas biográficas, vivos ou falecidos após 1945, apenas 16 de artistas negros ou mulatos.

CONFRONTANDO-SE o percentual brasileiro de artistas de cor, da atualidade, com os verificados (por indicaçâao biográfica $\Theta$ fotografia) na publicaçāo Pintores Cubanos, ed. R., La Habana, 1962, textos de E. Desnoes e O. Hurtado, sobre um total de 61 anotam-se seis negros ou mulatos, todos participantes da estatistica internacional. Raros são os artistas negros de formaçâo contemporánea comprometida à genuidade da Unidos, Cuba e países africanos, os artistes negros e descendentes se identificam e se afirmam através do comando do gosto coetâneo cosmopolita. Em nosso pais, raros são aque mestiços ou negros, de formaçāo cultura expressiva, vinculados à ternática e a valorização realizam por fé sóligena, qucontrada nas metive

Hélio Oliveira, xilogravador (Ba - 1932-1962), era neto do famoso babalorixá Procópio, de quem recebeu a herança e a responsabilidade sacerdotais do terreiro do Ogunjá. Agnaldo Manoel dos Santos (Ba 1926-1962) é caso de genialidade inventiva de umá temática atávica entretanto ornissa, em nossa experiéncia históric Deoscórides Maximiliano dos Santos, escultor e escritor, tem formaçäo sacerdotal para a hierarquia do Axé Opó Afonjá e artesanal no labrico de objetos itúrgicos. Waldeloir Rego, trajes do culto (colares, amúa de ados, jóiaş, etc.) tem iniciação religiosa e é estudioso de antropologia. Rubem Valentim (Ba - 1922), pintor de obra comentada no meio critico europeu, é de formaçẫo enudita e de devoçẫo de Omulu, com obrigaçōes religiosas.

dao temos outras indicaçỏes de obras individuais diagnosticadas pela coerência profundo sentimento de motivaçôes. Os conhecidos escultores Agenor Ferreira dos Santos e Manoel do Bonfim e o pintor Tibério såo negros e fazem obra referenciada aos temas, porém através da transculturação, da conhecidos, procedem de habilitacâa profissional de restauradores $e$ entalhadores $e$ de estúdio de produçăo acadêmica.
A ABORDAGEM dos historiadores e críticos de como de antropologistas, leva-nos mais incicaçắo de autores.

Arthur Rarnos admitiu influências das artes africanas na obra de artistas contemporàneos ram por continuidade temética ou por simplos eruditizaçăo conforme supomos". Inconcluso mesmo modo, parece-nos Mario Barata, quando afirma sobrevivência, mais na Bahia, de modelos africanos, em artefatos de madeira e metas destinados aos rituais do candomblé e devoções, negra brasileira' ${ }^{12}$.

Curiosa ilaçăo é a de Luiz Saia sobre os ex-votos do Nordeste, esculpidos em madeira, que lhe pareceram sob infueencias da escultura african José Roberto Teixeira Leite admite $\mathbf{a}$ arte afromericana, transplantada e desenvolvida, guardando entrelanto carater de origem. Conclu contemporânea da Bahia, nela trabalhando am escultor a quem reputamos ser um dos mais importantes do Brasil atual: Agnaldo dos Santos". José Valladares dá-nos noticia da temática predorninante, do material usado, do mercado que se formava em torno dos "primitivos" e dos Destaca um certo Rafael, do candomblé de Oxumaré, talvez o mais promissor pintor do grupo, que se omitiu corno artista ao se

Aceitando-se a generalidade de influência da cultura negra na manifestaçăo artística de atributos de uma tipologia e os expressam en termos de contemporaneidade, somarn-se ao nosso acervo, deste fenômeno de transculturaçáo, parte da obra de Hansen-Bahia, Carybé, Mánio

O PARTICIPANTE da cultura negra não é, no Brasil, necessariamente o negro. Tem acontecido
a humanistas e artistas brancos, de ascendência $e$
de procedência estrangeiras, fixarem-se às áreas remanescentes, integrando-se e valorizando as vinculaçס̄es, tornando-se intérpretes e estudio exemplos do etnólogo Pierre Verger ou nos plástico Hector Bernabo, ou Carybé, autor de um recente e já famoso mural dos Orixás, talvez o magnum opus de sua vida.

UM CAPÍTULO que requer novo estudo é o da presença de artistas negros entre os denominados Paulo Pedro Leat (Rio, 1894), Joāo Alves (BA. 1906), Waldomiro de Deus Souza (BA, 1944), José Barbosa da Silva (Olinda, 1948) merecem, para cada um deles, acurado estudo, porque trazem expressiva, arga de originalidade, de dos temas Neste gupo de Souza (Recife, 1926) e Antônio Maia (SE, 1928) negros como diagnóstico cultural. Um negro brasileiro de mérito é sem dúvida o mineiro Jair Brandāo, restaurador da DPHAN, de escolaridade européia, talvez mais artesão que artista, mas surpreendente sensibilidade junto à obra dos que ele preserva e restaura, $e$ às vezes identifica autoria.

ARTISTAS de raça branca, brasileiros ou não, de sangue eslavo, escandinavo, francês, italiano, obra de enaltecimento da figura negra e imado sem implicaçōes ao fundamento religioso. africano, porém com profunda afeiçâo ao tipo racial, aos costumes e valores culturais afrobrasileiros. Certo é que, em alguns deles, o
modelo negro, ou o tema, têm valor incidental no 
contexto da obra, embora por qualidade artistica se situem no nivel mais elevado de nossa produção pictórica.

Exemplos em que a figura do negro surge eventualmente, sem corresponder a urm a Tarsila do Amaral, de Alberto da Veiga Guignard, de Lucilio de Albuquerque, de Cândido Portinar, de Noêmia, de Djanira, de José Pancetti e do mestiço Thomaz Santa Rosa. Não é, pois, mesmo caso da temática de Emiliano Di grandeza quase como procura de arquétipo. nem a forma obsessiva do corpo da mulher negra, em estudos de busto e torso, do dinamarqués Mobbyy. São situaçōes comparávei à conduta classicista de exploração do mode conduzir toda, em que o imterprete parece

Não caberia ao artista negro enaltecer sua própria figura. Historicamente, a cultura negra tem se destinado a produzir valores emocionais para comunidade. Naquela data em que este foi 0 sentimento coltivola aos templos e ao artista da tribo, ressurgiu no Brasil e soube fazer acerto setecentista e oitocentista que admiramos e mal conservamos. Mas, na presente data, os caminhos das chamadas artes plásticas, embor franqueados, pouco interessam a alma tribal porque em muito pouco
emocionalidade coletiva.

O futebol, o candomblé, a macumba, a escola de samba e o carnaval formam todo um vasto mundo de estesia, bastante para refletir o vinculo africano, no negro ou no mestiço, naquele compromisso culural de inventar, compor e suprir

E nem é preciso dar nomes aos heróis dessas

Clarival do Prado Valladares

In: Cadernos Brasiloiros, ano X, n. 47. Rio de Janeiro, maio-julho, 1968

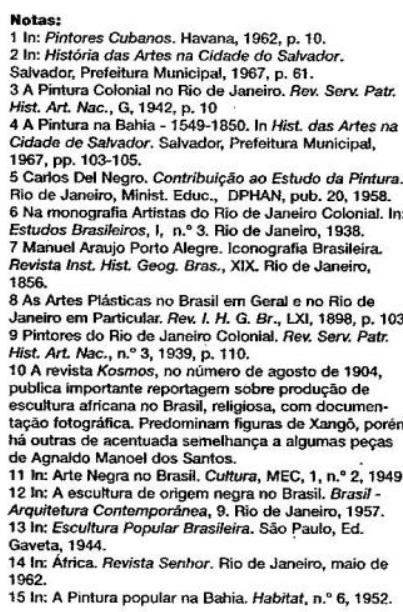

There are fow Black Brazilians involved these days in creating and promoting the so-called visual arts this is due to the high prestige of the arts among very much underrepresented. This phenomena less frequent in relation to mestico (mixed-racel artists who tend to be more easily accepted and assimilated into "white" society.

Social boundaries in Brazilian society are very strictly defined on the basis of economic position, but there is little racial prejudice in terms of
explicitly stated segregation. The exclusion individuals affects the poorer layers, and in certa areas of the country this sector consists largely of Brazilians of African descent. Blacks face the same dificulles as any other ethnic group, depending on their conomic stuation. So it is this accounts for the reduced Black presence in exclusive and sophisticated social activities

Since the end of the nineteenth century, this boundary has become more pronounced and is even more makked hoday, when what is accepted as art biects derived from the desire for ennoblement and prestige on the part of highsociety snobs - coupled with a disnegard for craft skills or cuitural commitment in artworks.

These pseudo-artists lack craft training and skills, and their preferred domains are the private much more by social events than by their cutt activities as such. Cursory examination of the annual solo exhibitions at these galleries reved the clear prevalence of promotional activity exhibitor.

Colored artists usually get opportunities when they are identified with a certain type of work consuming public. This acceptance and praise is focused on primitive art with its docile and anodyne poetics, to the extent that naive collections or to serve as decorations where a cultural atmosphere is sought.

Few Black and mixed-race artists develop their work according to more demanding standards, most play the game according to the rules set by their "primitive" artist to be colored - Bla wa mulatto or Indian - and from a poor background, in order to provide authenticity of origin for their work. This is not the case generally, but it is one of the characteristics of the ruling elite, for those aspiring to a certain intellectual air. Driven by the and influence the canons and standards of artwork creation, or they themselves become artists. With influence trafficking they may ettain an encen attain an seem to justify all the worry and risk involved.

For members of the elite, there are talents provided fortuitously by Nature and they wish to have access to them. This is something very different to the ethos around the large numbers of in full force, achieved social promingeren still the high-quality artwork created by their craft skills and artistic talents. This is an issue that has been touched on by almost afl art historians and sociologists working on Latin American cultures

Oscar Hurtado pointed out that in colonial times, a job such as painting was a lowly task and see brought over decorator-monks who employed the lower classes - consisting at the time of mulattos (pardos) and Blacks - to decorate may be, monasteries and other institutions. It

There was a similar period in Brazil, from the earty eighteenth through the nineteenth century. In the words of Marieta Alves, the nineteenth century was far from barren in relation to the vocation of sill the artists of irnat inould just remark that almost mixed race - colored lads / cabras pardos - as far as we can see from death and marriege records. He goes on to mention eight well-known sculptors of images of the period. . $^{2}$

Hanna Levy suggests researching the old registers of Black churches and sodalities that statements by competent authors indicate that Leandro Joaquim, Manuel da Cunha and Raimundo da Costa e Silva were mulattos." Carlos Ott points out that in a list of 231 painters, artsans ald artists or this pentiod, $t$ hoo were slaves, only one of them known by his own masters. 'Blacks and mestiços predominate in century, and apart from the great works of Antonio da Silva Lisboa, the mulatto artist

Francisco Marques dos Santos provides ample coverage of this topic." It is known that Master Valentim (Valentim da Fonseca e Silva) was the son of a minor Portuguese nobleman, holder of a 


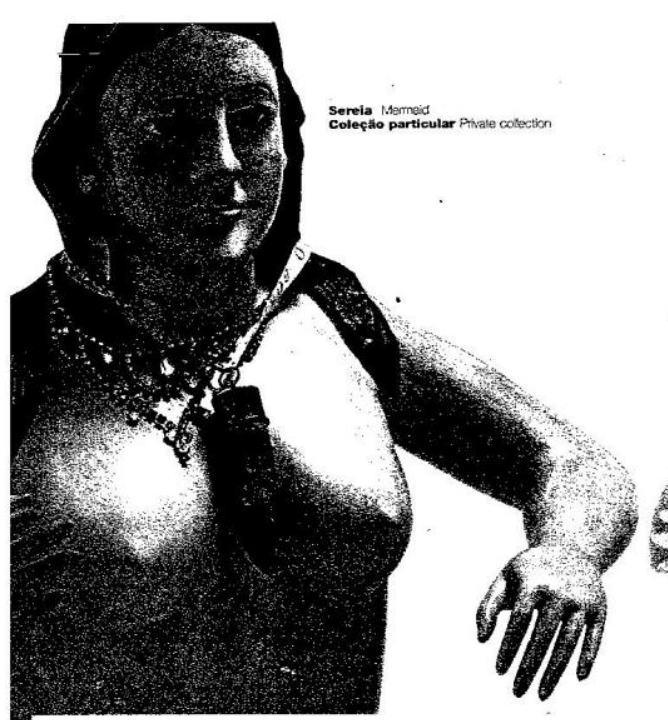

Quando se investigam as origens dos rituais africanos no Brasil, surpreende o fato de năo se encontrarem em icones esculpidos em madeir áreas africanas supridoras de escravos e aind vigentes nos mesmos cultos daquele Continente'. Algo houve capaz de interromper a continuidade das normas tradicionais dos cultos africanos, anulando por completo a elaboraçāo
dos objetos dependentes de desenvolvimento dos objetos dependentes de desenvolvimento raros exemplares de imagens esculpidas o. St. instrumentos de ritual procedentes da Átric

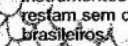

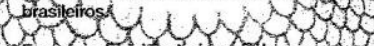
Em nossabobinia, leriang unde em malon. especiaimente darárea nígeriana de ling wat

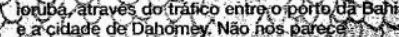
possivel a móntaçá, ou mesmo apos decharada ytonsilias e srobolos.

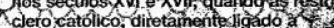

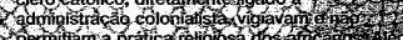

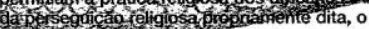
escrave anteanerpar'se tinha ainda afirmado en comunidades transculturadas - irmandades e cor - nem se realizado em niver econ̂mico bastante para se impor, a ponto de pratica abertamente sua religiosidade.

O surgimento dos candomblés com posse de terra na periferia das cidades e com agremiaç de crentes e prálica do calendario verifica-se incidentalmente em documentos - crónicas a qualquer historiador descobrir documentos do periodo anterior diretamente relacionados à prática, permitida ou sub-repticia, de rituais atricanos. A propria igreja católica admitia segregacionismo social e racial. Diogo de sociedade estava profundamente dividida em classes $\mathrm{e}$ até em cores; pelo que se fizeram diversos santuarios para que à vontade orasse os fiéis de cada agrupamento".

Talvez o documento mais remoto denunciador da prática de um ritual africano remanescente do primeiro Bispo Visitador de Minas Gerais, Frei Antônio de Guadalupe, datado de 1726 e divulgado nos Mandamentos ou Capitulos d Visita. Na interpretação do historiador, advertência do Bispo aos vigários contra otruque dos senhores de terras betizarem se africanos em paroquias diferentes da sua, ain não convenientemente catolicizados. D. Frei Antônio de Guadalupe em determinado trech faz uma narraçāo quase completa de um do Tais important Achamns que alguns escravos, principalment sua gentiliódé, tazend algumas reliqujas da com vozes e inistrumentos em sufrágiós de se

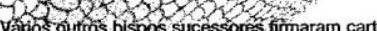

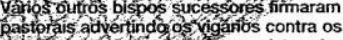

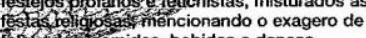
aíficamente de bebidas e danças ao instrumentał de percussão necessário ao ritmo da música africana. O tempo necessário para o africano atingir acordo com a fertilidade das terras e a estabilidade económica das regiōes. Isto é, dependeu do tempo necessário para perm escravo menos trabahtho na lavoura ou na
mineração e maior participaçāo nos afazeres mineração e maior participação nos afazeres
domésticos da casa dos seus senhores. Nas recomendaçōes do Bispo Visitador de Minas Gerais, em 1726, adverte-se contra os senhor que permitiam e davam acolhida à prática fetichista.

Poderiamos afimar, a grosso modo, que o sincretismo religioso africano-católico no Brasil primeiros mestiços. A mulher negra foi o instrumento principal no caminho da integraçäo social do escravo. Nẫo conseguiu fazê-lo pela atraçáa somente do seu corpo, porém muito mas por muatilingencia, crinco habilitade no enriquecimento da culinária a anrendizaoem rábida das orendas da mulher

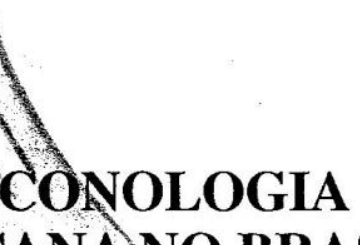
ANA NO BRASIL

branca no fratamento dos objetos e serviços das obnigacōes do culto católico através do cantarejo das oraçoes, da decoração das capelas e da pantomirna litúrgica. Muito cedo o filho da escrava preto ou mulato, era o companheiro do cita do negro voltar so eito a do branças ates para éducar-se nas metrópoles. Tais aspectos da formação e da história natural da familia brasileira prodigamente estudados por nossos sociólogos, formam o quadro de um periodo de cerca de do sculos em que a iconografia aficana se

A

A amplitude da mestiçagem das três raças no Brasil faz uma escala de valores e atributos, manifestados também nas artes eruditas e populares, que poderiamos identificar como caráter brasileiro. Nesta conceítuaçẫo, ê

necessário nâo se contundir a genuidade com a ser nas artes indigenas que sảo expres. A náp um comportamento neolitico, todos os demais acontecimentos, desde a colônia, sâo nitidamente processos de transcuituraçăo.

Tais processos ocupam longos periodos, regiöes agrupamentos sociais, fecundam as artes populares mediante o sincretismo das culturas importadas e também se manifestam, em termos de motivaçöes, nos niveis sofisticados das artes de elite. O exemplo mais próximo encontra-se no do rontismo europen que aqu se neturatizou nas formas do indianismo, do nativismo, do inconfidencialismo, do verde-amarelismo, do próprio tão falado modernismo brasileiro, referente a semana de 1922 em Sáo Paulo, e de suas decorrenclas (movimembs imelectuais ansiosos de regionalismo, romance do Nordeste etc.).

Não é de se estranhar que muitas de nossas pesquisas em Ciências Sociais apareçam revestidas daquela motivaçaoo romantica, isto é. daquele sentido nacionalista dos que anseiam autodeterminaçáo e quebra da delasagern pera toda obra do sociólogo Gilberto Freyre, do humanista Mário de Andrade e dos numerosos seguidores se identificam nessas direçōes. Năo se pode vê-las defeituosas por seus compromissos linicos. Para os que pretendem a 


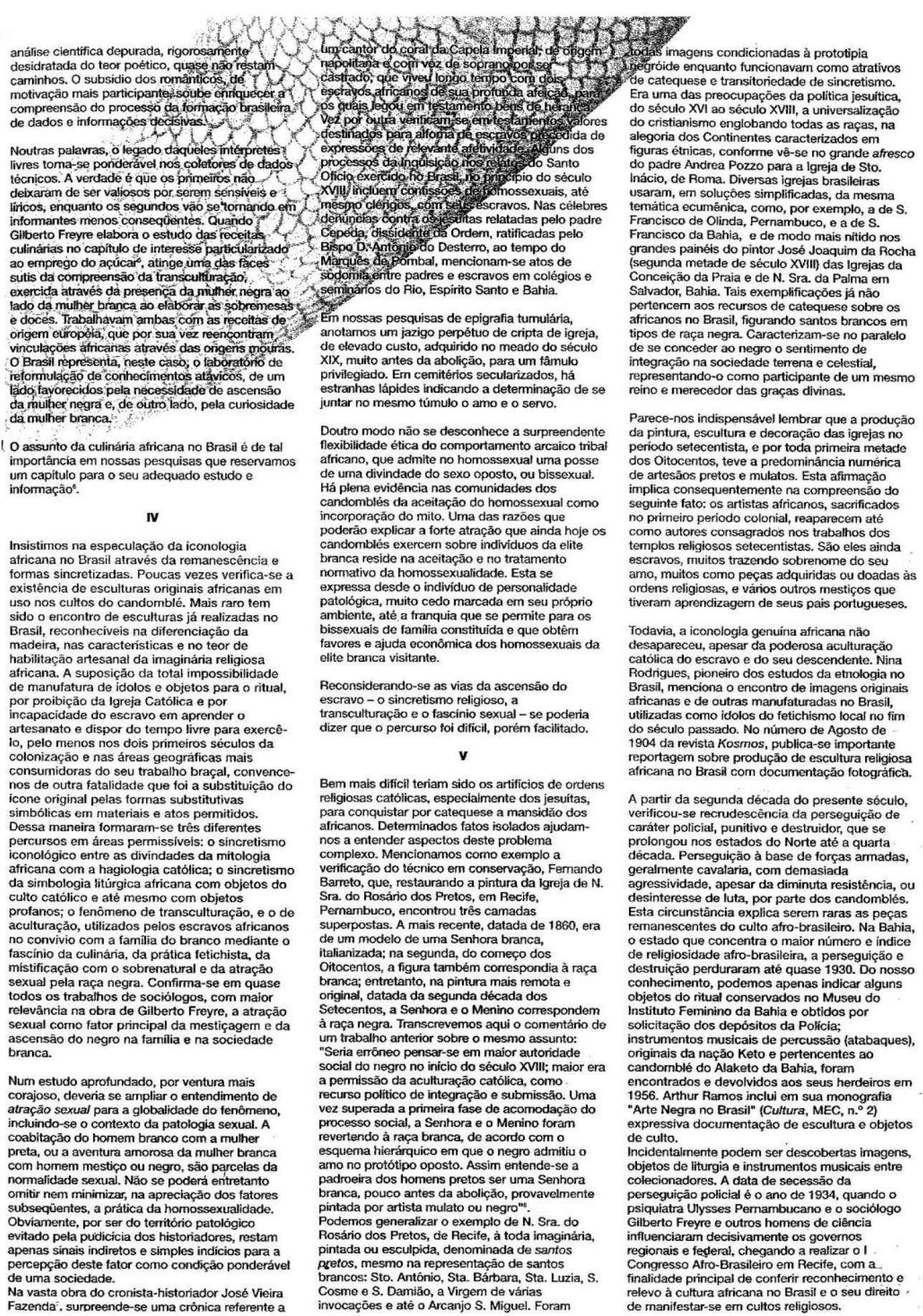


Tínhamos, entretanto, informaçăo, através de um artigo de Abelardo Duarte, da existência nos depósitos do Instituto Histórico de Alagoas, de surpreendente quantidade de icones, objetos
liturgicos, instrumentos musicais e trajes de ritual, apreendidos nos anos de 1910 e $1912 \mathrm{e}$ recolhidos pelo entazo delegado de Polician renr 12. Em 1968, fomos a Maceió proceder à pesquisa documentaçāo fotográfica desse acervo. Em nossa opiniấo, trata-se da fonte mais importante para qualquer estudo que se queira fazer no $B$ em relação ao sincretismo, além do relevante $\mathrm{O}$ acervo iconológico alagoano pode dividir-se nos seguintes conjuntos:

1) Imagens, todas esculpidas em madeira entre os séculos XIX e XX, de dimensőes variáveis de 5 a $22 \mathrm{~cm}$, representativas de divindades africanas sincretizadas a inaginania católica Muitos despondem à figura feminina de $\mathrm{N}$. Senhora com o Menino ao colo e em traje dos modelos católicos. Algumas trazem olhos de vidro, idénticos aos usados naquela época pelos santeiros do artesanato de imagens católicas. OS caracteres da genuinidade africana permanecen cabeç̧a (machado bi-facial), ou do Oguê configuraçāo bicómea). Estas imagens en rontalidade correspondem à composiçăo tradicional das figuras de N. Senhora do Rosário carregando o Filho. Algumas se assemelham à N Senhora do Amparo ou do Parto, com a figura do Menino deitado sobre os dois braços, e poucas Foram todas inspiradas em modelos de uma época barroca, entretanto solucionadas em atitude hierática, imobilidade e sintese de acordo com a iconografia arcaica tribal. Destaca-se o importante detalhe de quase todas carregare costas uma gamela com objetos-símbolos acabamento é de madeira encerada, e em uma nota-se pintura de pontihado branco por todo corpo; duas ainda conservam trajes de panos bordados em contas e búzios, imitando as vestes clericais da cerimônia da missa católica. Havi uma figura recoberta de traje que, retirado, em atitude de coito. Úma única vez encontramos escultura de inquestionável procedência african facilmente diagnosticável pela quatidade da madeira, destreza artesanal e prototipia dos icones represent

A nudez é evidência de iconologia original africana, enquanto a figura vestida indica ausência de panejamento barroco movimentado, nas escilturas dos candombles, nao é devida incapo por outra expressividede, mais identifica ao comportamento arcaico, do escravo.

Assim se poderá entender o sincretismo afrobrasileiro em niver do arcaico e do barroco; do primeiro mantendo a atitude hierática das figuras, prez, a sicho da imaginária católica ainda hoje produzidas nos agrupamentos sociais do sertăo brasileiro, culturalmente identificáveis ao comportamento arcaico, verificam-se essas caracteristicas vindas do tribal africano, de

2) Conjunto de objetos da liturgia afro-brasileira. 0 Instituto Histórico de Alagoas possui no mesm acervo numerosas coroas, oxês (cetros) capacetes e armaduras, braceletes, abebês (folhas de metal recortadas), xaxarás (cetros de Omolu) e ogués de Oxassi (chitres revestidos de abictos são de foltha de metal fragrnemtos de tubos e de pecas e viensilios variados. Destaca. se uma coroa de $42 \mathrm{~cm}$ de metal amarelo no formato initativo da coroa do imperador brasilei todavia encirnada pelos símbolos do oguê e do oxê de Xangó. Da mesma procedência e colth búzios importados da África conforme modelos originais. O que nos permite atribuir confecção brasileira é o encontro de pequenos espelhos emoldurados incluidos entre os búzios de um armadura, destinados ao uso profano constitui do da Europa Un dos capacetes se unichs por fio de arame estanhado. Neste acervo nota-se curiosa diferenciação dos abebês, que na área baiana não possuem base $\mathrm{e}$ por isso se integram como objetos do traje, enquanto os de Alagoas são fixados a uma sólida base, dandoThes a aparencia de ostensorios. Todos sẫo de soluçēes de rigica simetria Nos objetos simbólicos de Oxumaré (arco e flecha em ferro malhado) e nos simbolos de Ossanhe (forqueaduras fitomórficas), pode-se avaliar o domínio artesanal de ferreiro exercido pelos aficanos e descendentes. Juntamente com os outros objetos de materiais diversos, se const soldagem, de laminação, de polimento e da capacidade decorativa. Todos esses achados sâ. provenientes de uma área geográfica pobre de processos industriais, historicamente dedicada plantio de cana de açúcar. Os trabahhos com

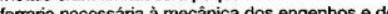
transporte primário. Algumas peças de lâmina de metal recor de embalagens de mercadorias importadas. Em um único exemplo verificamos sincretismo com a arte turnulária católica. Trata-se de um abebê com dernato palavra e da insch éça ente fonética de $E G U M$ referência do morto; OXUM é a divindade feminin sincretizada à N. Senhora das Candeias, uma das mulheres de Oxalá na mitologia iorubá. Parece
tratar-se de objeto de consagraçāo funérea de tratar-se de objeto

O sedimento histórico da iconografia africana no Brasil tende a desaparecer, substiundo-se pelos protôtipos da comunicaçao visual que a civilizaçăo corrente impóe. A prática do culto cermanecera com o crescimento das grandes simbologia e em varic candomblé. Macumba corresponde à transitoriedade do candomblé na adaptaçáo à metrópole, com o ingresso de uma expressa mica representada na figura do cabocto, o de ritune braslein. Umbanda é a sincretizaçăo Caboclo identifica com precisão o abrasileiramento do culto africano. Para todas essas derivaçöes, elaborou-se uma iconografia substitutiva de objetos produzidos Un attigos para Umbanda ou para exuberante variedade de imagens de cerâmica tabricada em moldes prensados, adereços,
amuletos, defumaçōes e infindável sortimento de ervas e infusóes para o receituario dos males do corpo e para cura das ansiedades. Surpreende verifcar-se que a conspicua demonologia dos tempos passados, representada no Exu dos procede dos protótipos fermininos do cinema Hollywood, carregados de sex-appeal sob denominaçáo local de Pomba-Gira. Até o próprio caboclo, autêntico em sua origem, achepre corlo de Vênus de Milo, figuras leoninas, S. Jorge, N. Senhora Aparecida, bustos e várias outras modelagens participam hoje da imaginária macumba urbana. N. Senhora das Graças, N. Senhora de Fatima e de Lourdes, assín como a primitiva divindade de lemanjá, a rainha das águas.

O crescimento demográfico corresponde ả maior intensidade de cultos primitivos toda vez que de insegurança. Os sinais da autenticidade $s e$ dissolvem $e$ desaparecem, enquanto permanecem as razōes das atitudes primárias. Lembrar a noite do dia 31 de dezembro de cada ano no que ocorre ao longo do litoral do estado dosen de velas acesas e se as praias oferendas votivas à lemanjá, é a maneira mais simples de se demonstrar a remanescéncia e a recrudescência de uma primitiva iconografia. Se a genuinidade desapareceu nos seus aspectos particulares, doutro modo resultou na imensa cartografia de uma reglao pont hada de velas cada noite nas favelas e nos apartamentos $d$ Copacabana, e em milhas da linha do mar na última noite de cada ano.

Clarival do Prado Valladares

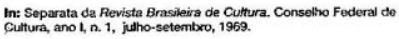

Nota: O Autor agradece a Manoel Diegues Junior e Luís Śrvio de

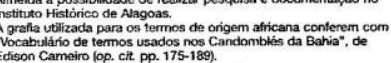

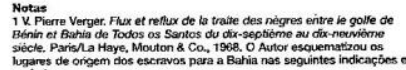

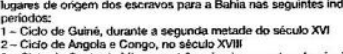

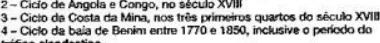

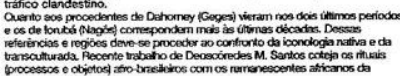

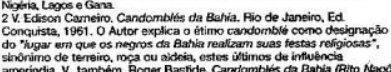

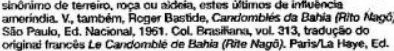

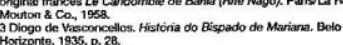

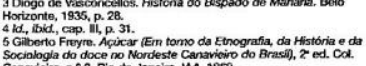

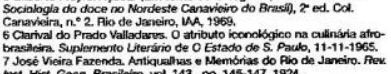
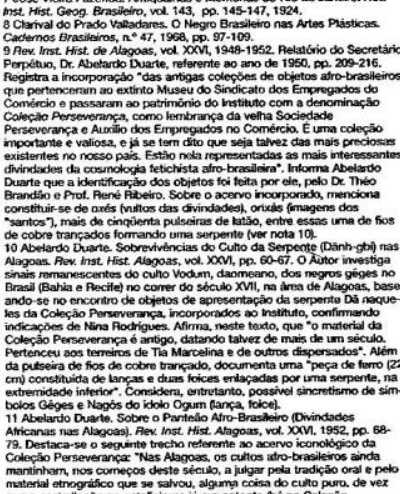

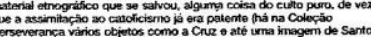

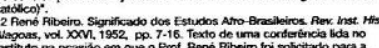




\section{Texto de Rubem Braga, capítulo do livro Três Primitivos sobre Heitor dos}

\section{Prazeres.}

\section{HEITOR DOS PRAZERES}

Sua pintura é uma flôr nutural de seu samba e de sua vida, de seu meio e de suas mulatas de quem êle desenha com amor todos os dentinhos brancos:

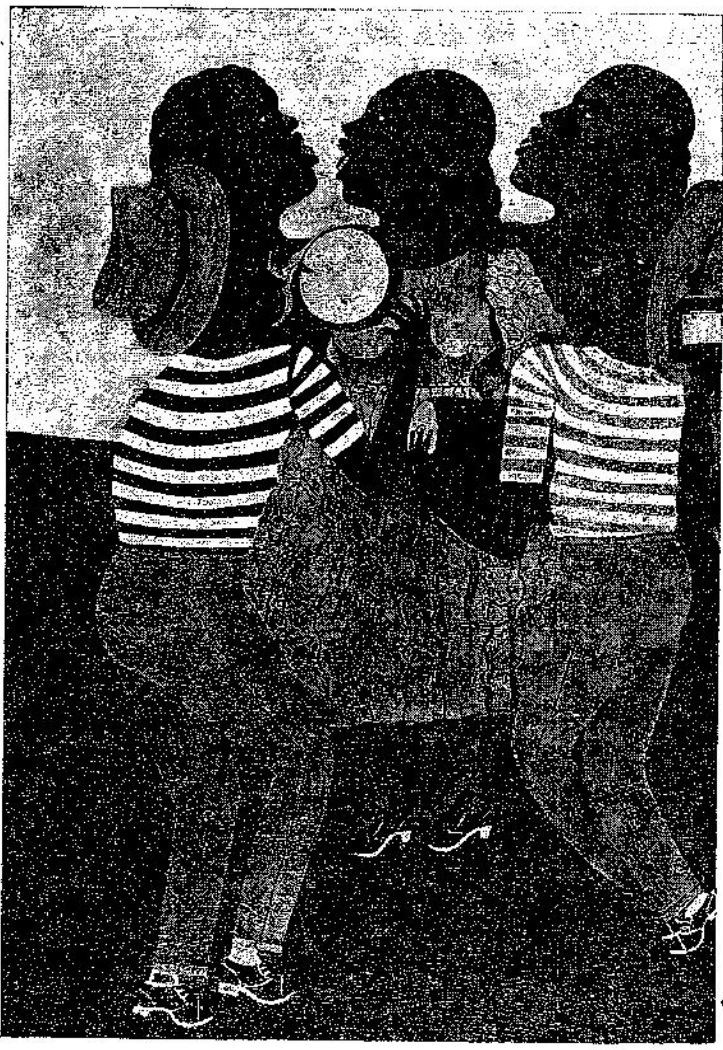

ros. Uma vez se encontron eam Noel Rusa, e Noel perguntou o que êle tinha para o carnaval. Batendo na caixa đe fésforos dentro do bôlso, co meçou a resmungar ana marehinh que timha 11 a cabeça: "Um pierrot apaixonado... qư vivia sô cantan-

Os dois ajeitaram a segunda parte. e a música de parceria atravesson malandro", "Deixaste men lar" "Progresso" (por ocasiāo da revoluçẵo ồ "Nossa Separaçã̃o", "Desperta Dodô". Depois de muitos amôres casou, te ve seis filhos, fora uns 'der gue tere antes e depois, pois hoje atć vovô), levou o samba a déu e jamzis pensava em pintura Foi en 1937 que comecou a fazer uns qui drinhos "para enfeitar a parede". jornalista e desenhista Carlos Carialcanti o estimulon, disse que êle tinh jeito; suas primeiras aquarelas fica. ram com vicente Leite. Gomeyor a fazer uns óleos muito escuros.

Hoje é funcionário do Miusstêrio da Educação, onde nm arquiteto in teligente, Jorge Ferreira, ihe deixa tempo para pintar, e é ritmista da Rádio Nacional. Ganha poues, ten mulher e uma filharada, mas sinpre bem vestido, com os paletús desenhados por éte mesmo, botäers nos bolsos, invariavelmente linipo e cor reto, como ain "gentleman nesro" ique tivesse, como tem, um "Mêtơơ de

Em urna das suas letras de samba Heitor diz à amada: "meu amor por ti são flôres, tudo tlôres naturais"s" Sua pintura é uma flor natural de selu samba e de sua vida, de ser meio e de suas mulatas de quem èle dese nha com amor todos os dentinhos drama social vamos exprime algum em que aparee a em que apare a gente pobse carre.

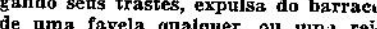
vindicaçāo racial, como naquela de jantar em que uma familia preta é servida por uma copeirí branea, quase senipre reflete momentos andenos da vida da gente do samba, nâ bem a de hoje, mas os do tempo ia zntigo, em que para alêm de são Cristovāo o Rio de Janeiro era muito rural. Esse homem que começou a pintax
quarentäo conta em suas telas, muitas vêzes, recor em suas telas, mui disse que o quadro que fêx da Onze no carnaval, e gue vi Trag de Carlos Drumond de Andrade, fêz depois que a Praça Oonze não mais assim. Como em tanta música urbana (viừe Catulo), há em sua pintura, às vêzes, nma ressonância tạ roga em que êle nunca viveu, inares de sertáo e frisos de cana-de-acúcar caboctos do mato; assira é mais fiel à sua eidade, cujo sentimento rural sem pobres que vêm vindo rrnovain cem cessar, e mesmo um homem nas. sil, lados do pais "essencialmentos exicola".

Se hã um homem que não precisava ser pintor era êsse, caja vida o amôres já conta de maneira täo, boa queza interna veío sua imensa rira uma expressão irma do na pintu. seria fácil reconhecer o ritmista composiçấo dos quadros, o "envernizador téenicb" no seu acabamento caprichado, o boêmio nos motivos ma. landros que 0 inspiram. Ėle não faz pintura "do Partido Alto", para deleite dos ricos, nem traz para a tela as cenos de macumbas e candomblés que frequientou, apenas conta essa vida solta e heróica de cavaquinho ha mão e cachaça e mulata, sua vi. conguistas "n-̄o pela caror de muitas mas pela conversa cura que tenho, Sua arte é, por isso, como êle mesSua arte é, por isso, como êle mes-
mo, uma expressão legítima de um Rio de Janeiro atrapalhado e saborar a gôsto intensíssimuca póde 